
DA ORGANIZAÇÃO JUDICIÁRIA EM PORTUGAL NO PERÍODO DAS LEIS GERAIS (1211 - 1446) 
JOSÉ ROBERTO LEME ALVES DE OLIVEIRA

\title{
DA ORGANIZAÇÃO JUDICIÁRIA EM PORTUGAL NO PERÍODO DAS LEIS GERAIS (1211 - 1446)
}

\author{
DISSERTAÇÃO DE MESTRADO \\ Orientador: Professor Titular Luiz Carlos de Azevedo
}

FACULDADE DE DIREITO DA UNIVERSIDADE DE SÃO PAULO

São Paulo

2010 
JOSÉ ROBERTO LEME ALVES DE OLIVEIRA

\section{DA ORGANIZAÇÃO JUDICIÁRIA EM PORTUGAL NO PERÍODO DAS LEIS GERAIS (1211 - 1446)}

Dissertação de mestrado apresentada como requisito parcial para obtenção do grau de mestre na área de concentração de Direito Civil, sob orientação do Professor Titular Luiz Carlos de Azevedo.

FACULDADE DE DIREITO DA UNIVERSIDADE DE SÃO PAULO

São Paulo 


\section{ÍNDICE}

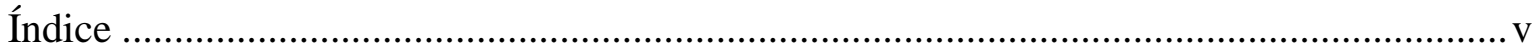

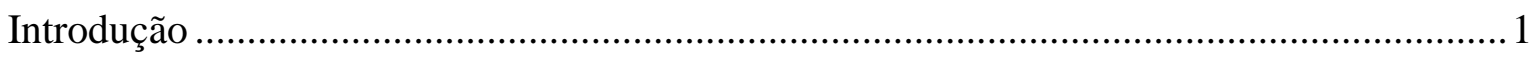

1. Fontes do direito durante o período das Leis Gerais ........................................................ 3

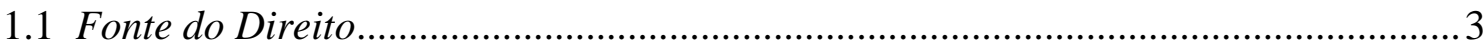

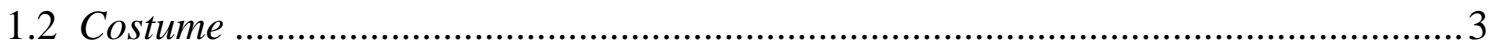

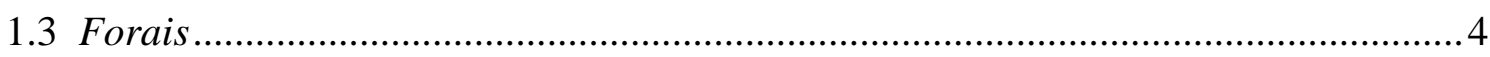

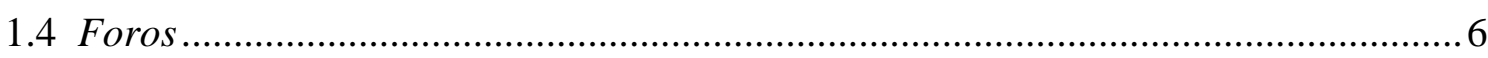

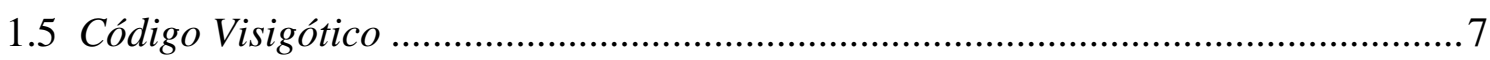

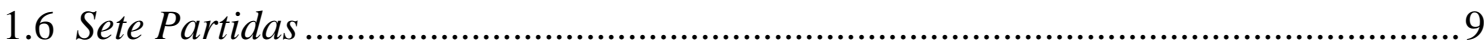

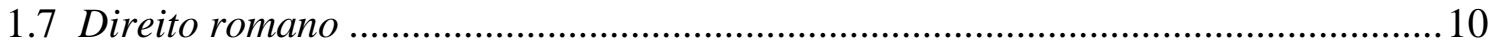

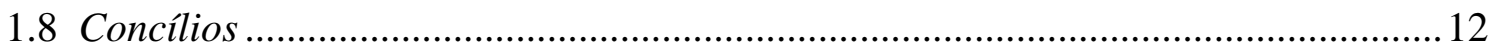

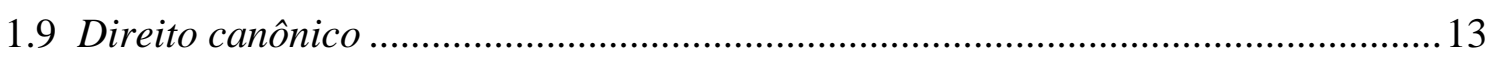

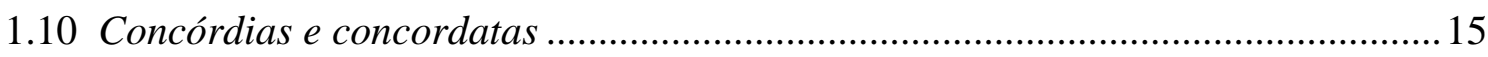

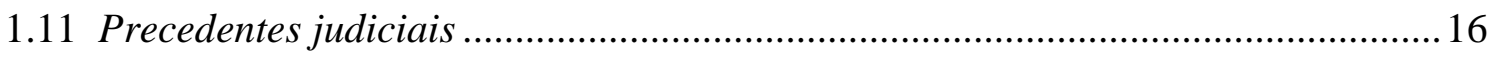

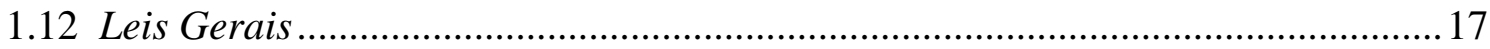

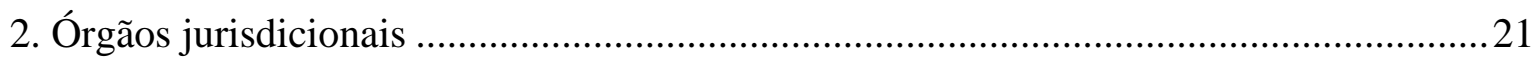

2.1 O papa

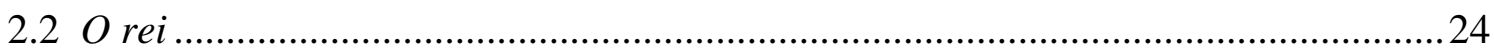

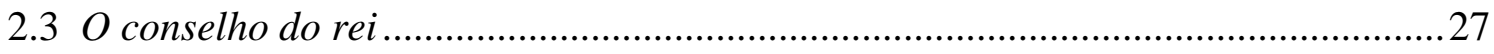

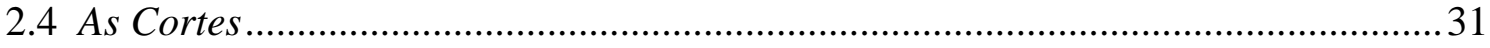

2.5 Jurisdições militares: alferes-mor, condestável e marechal da hoste ....................... 34

2.6 As jurisdições palatinas: mordomo-mor, chanceler e escrivão da puridade ............ 35

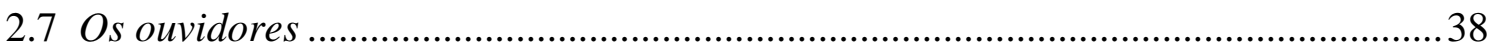

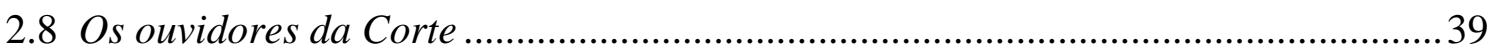

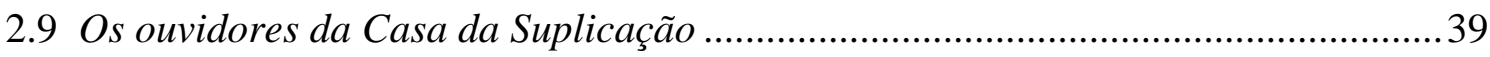

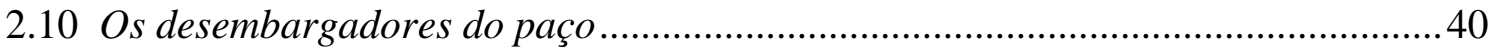

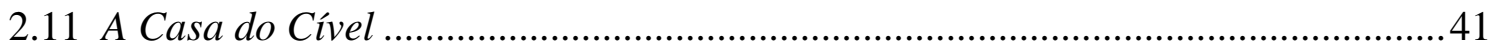

1.12 O porteiro-mor, ouvidores da portaria e ouvidores da fazenda............................ 41

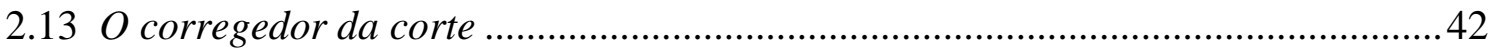

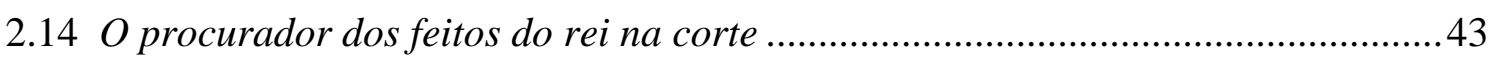


2.15 Ouvidor das terras da rainha

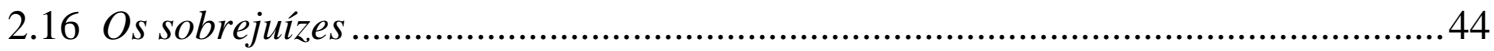

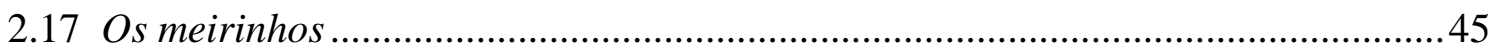

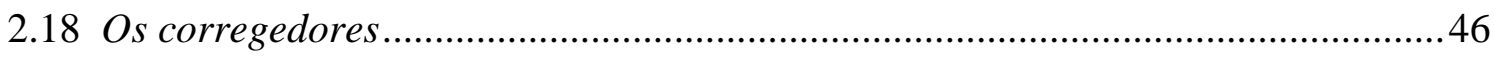

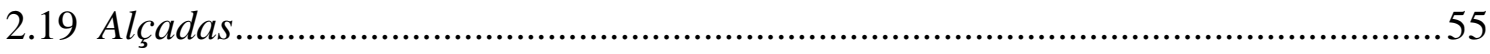

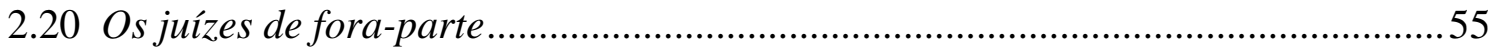

2.21 Os alcaides-mores e alcaides-menores ou pretores e vice-pretores .......................57

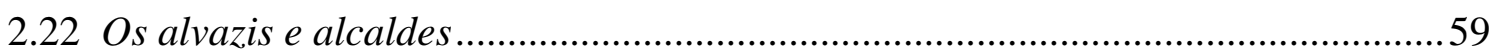

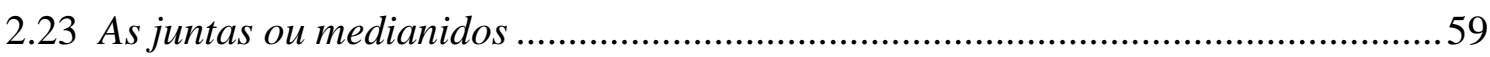

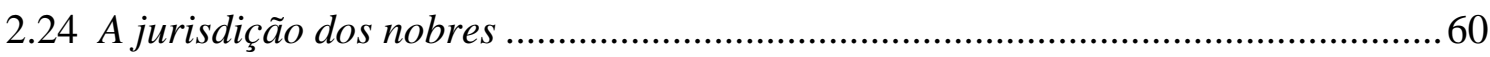

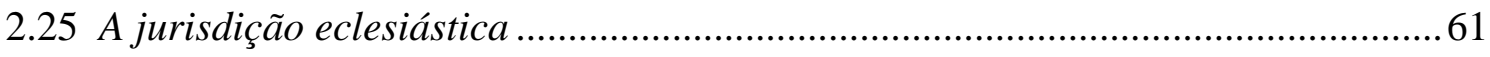

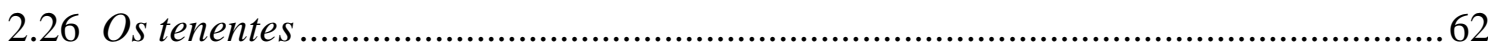

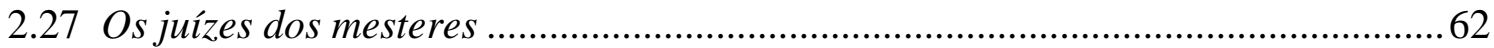

2.28 O conservador da Universidade de Coimbra ...........................................................63

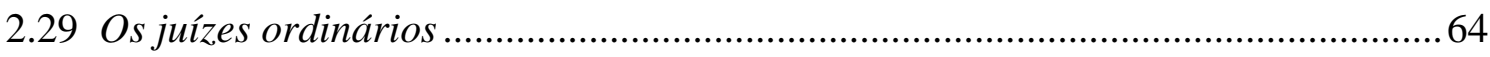

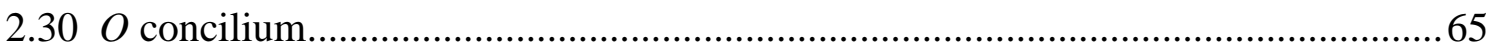

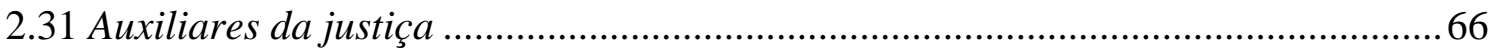

3. Reminiscências da organização judiciária medieval portuguesa no Brasil contemporâneo .68

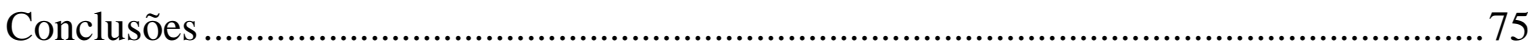

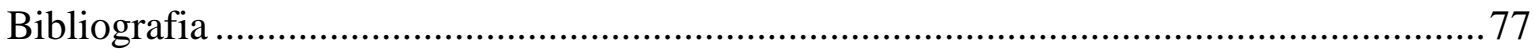

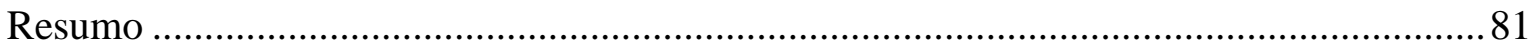

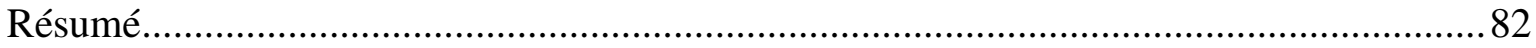




\section{INTRODUÇÃO}

Esta dissertação tem por objeto a forma pela qual se organizou a distribuição da justiça em Portugal antes da promulgação das Ordenações Afonsinas (1446).

Os limites geográficos impostos pelo tema não permitiriam, em princípio, que a investigação se estendesse a outros Estados soberanos. Entretanto, ao longo do texto se encontrarão algumas referências a Castela e à França. A justificativa para essas duas exceções é a inegável influência que esses reinos exerceram sobre as instituições jurídicas portuguesas, as quais, no momento da independência (1140), foram idênticas às castelhanas. Só com o correr do tempo é que Portugal foi diferenciando-as das de Castela. E sua primeira dinastia, francesa de origem, manteve-se ligada de modo particular à França, tanto que, quando D. Sancho II foi deposto por decisão papal (1245), seu irmão, D. Afonso III, que assumiu o trono, prestou seu célebre juramento em não outro lugar senão Paris.

Quanto aos limites cronológicos fixados pelo tema, impõem-se alguns esclarecimentos.

No primeiro capítulo, em que se examinam as fontes do direito em Portugal de 1211 a 1446, se verá que, não obstante a designação «período das Leis Gerais», tais leis não foram as fontes do direito exclusivas, sequer as predominantes, durante essa época. Sendo assim, é válida essa designação, embora diversos historiadores do direito prefiram outras, porque as Leis Gerais foram a primeira legislação originalmente portuguesa que teve vigência em todo o território da jovem nação.

Esse exame deve ser feito a partir da avaliação do grau de autoridade que cada uma das fontes do direito teve ao longo dos diversos momentos que compõem esse período. Porque, se nos primeiros anos da monarquia houve o predomínio do costume e dos forais, com alguma sobrevivência do Código Visigótico e também emprego dos Santos Cânones, ao longo do século XIII tais fontes do direito perdem a autoridade e cedem a proeminência ao Código de Justiniano e ao Decreto de Graciano. E a promulgação de Leis Gerais foi constante durante todo o período. Desse quadro decorrem diversas possibilidades de divisão da história do direito português em períodos, a partir das fontes, sem que haja consenso entre os doutrinadores: M. J. DE AlmeIDA COSTA denomina o 
período que vai de 1140 a 1248 de «individualização do direito português», e o que vai de 1248 a 1445, de «inspiração romano-canônica». Para M. CAETANO, 1140 a 1248 é o período de «Formação do Estado», e 1248 a 1495, o de «Consolidação do Estado»². Já para N. J. Espinosa Gomes da Silva, acompanhado por J. R. CRuZ E TuCCI e. L. C. DE AZEVEDO $^{3}$, o período que vai de 1140 a 1248 é o do «direito consuetudinário e foraleiro», e o de 1248 a 1750, o de «influência do direito comum», que se subdivide em três épocas, a primeira das quais, que vai de 1248 a 1446, é a da «recepção do direito comum» ${ }^{4}$.

Da escolha das Leis Gerais como critério de periodização decorre a necessidade de deslocar o termo inicial adotado pela maioria dos historiadores de 1140 para 1211, excluindo-se os reinados de D. Afonso Henriques (1140 - 1185) e de D. Sancho I (1185 - 1211), pois do primeiro se conhece apenas uma lei sobre as barregãs dos clérigos, e do segundo, a lei que isenta os membros do clero do serviço militar, salvo a hipótese de invasão muçulmana ${ }^{5}$. Assim, as primeiras Leis Gerais foram promulgadas por D. Afonso II, durante as Cortes de $1211^{6}$.

Evidentemente, o exame particularizado de cada uma dessas fontes não poderá ficar adstrito aos limites cronológicos mencionados no tema da dissertação.

O terceiro e último capítulo se propõe a averiguar quais reminiscências da organização judiciária medieval portuguesa podem ainda ser encontradas no Brasil contemporâneo. O direito português teve vigência no Brasil por mais de três séculos e o Brasil herdou a cultura jurídica portuguesa em 1822 da mesma forma que Portugal herdara a cultura jurídica de Castela em 1140. O nosso direito contemporâneo se edificou sobre essa base, o que mostra a relevância do objeto escolhido.

\footnotetext{
${ }^{1}$ M. J. DE AlmeIDA Costa, História do direito português, Almedina, Coimbra, $3^{\mathrm{a}}$ ed., $9^{\mathrm{a}}$ reimpressão, 2009, p. 174-75.

${ }^{2}$ M. CAetano, História do Direito Português, Verbo, Lisboa - São Paulo, $4^{\mathrm{a}}$ ed., 2000, p. 31.

3 J. R CRUZ E TUCCI e L. C. DE AZEVEDo, Lições de história do processo civil lusitano, RT e Coimbra Editora, São Paulo, 2009, p. 29.

${ }^{4}$ N. J. ESPINOSA GOMES DA SILVA, História do direito português, Fundação Calouste Gulbenkian, $4^{\mathrm{a}}$ ed, 2006, p. 38-40.

${ }^{5}$ P. Ferreira da Cunha, J. Aguiar e Silva e A. Lemos SoAres, História do direito, Almedina, Coimbra, 2005, p. 368. A lei atribuída a D. Afonso Henriques, que mandava prender as mulheres encontradas em trato ilícito com sacerdotes, foi posta em vigor ao tempo de D. Sancho II: oficiais públicos, à noite, arrombavam as portas dos eclesiásticos e, quer os achassem com mulher, quer não, infamavam-nos, além de roubar-lhes as alfaias. Alguns padres, para preservar a reputação, muitas vezes faziam acordos com esses oficiais (A. Herculano, História de Portugal, t. 4, Livrarias Aillaud \& Bertand - Livraria Francisco Alves, Paris Lisboa - Rio - São Paulo - Belo Horizonte, $8^{a}$ ed., p. 223-34).

${ }^{6}$ M. CAetano, História do direito português, Verbo, Lisboa - São Paulo, 4ª ed., 2000, p. 241.
} 


\section{FONTES DO DIREITO DURANTE O PERÍODO DAS LEIS GERAIS}

\subsection{FONTE DO DIREITO}

Fonte do direito, como ensina J. R. CRUZ E TUCCI, é termo de dupla acepção, que significa tanto a origem do direito objetivo quanto o veículo de conhecimento do direito ${ }^{7}$. Aqui, a expressão «fontes do direito» é empregada em sua primeira significação, ou seja, no sentido de «formas de expressão do direito».

\subsection{COSTUME}

Costume, segundo J. GILISSEN, é o «conjunto de usos de ordem jurídica que adquiriram força obrigatória num dado grupo social, pela repetição de actos públicos e pacíficos durante um lapso de tempo relativamente longo» ${ }^{8}$.

Era a fonte principal, quase exclusiva, do direito privado. Seu elemento material é a prática constante e reiterada de certa conduta; e seu elemento psicológico, a convicção de sua obrigatoriedade 9 .

Sua preponderância já havia sido reconhecida pelo Concílio de Leão, em 1020, que mandava «guardar o costume da terra» ${ }^{10}$. Para M. CAETANO, explica-se essa primazia pelo fato de, até o final do século XIII, não haver ensino do Direito em Portugal, e a justiça ser administrada por juízes eleitos, muitas vezes analfabetos ${ }^{11}$. N. J. EsPINOSA GOMES DA SILVA, entretanto, aponta dois motivos para a importância do direito consuetudinário: primeiro, as atenções do Estado da Reconquista eram voltadas para a guerra, não para a administração ou a produção legislativa; segundo, de acordo com as concepções de direito público germânico, o rei deve observar o direito, não criá-lo, pois ele é juiz, não legislador ${ }^{12}$. E R. PERnOUd, ao examinar a mentalidade medieval, revela aspectos que não podem ser olvidados: o temor das conseqüências imprevisíveis de tudo o

\footnotetext{
${ }^{7}$ J. R. CRUZ E TUCCI, Precedente judicial como fonte do direito, RT, São Paulo, 2004, p. 19.

${ }^{8}$ J. GILISSEN, Introdução histórica ao direito, Fundação Calouste Gulbenkian, Lisboa, 1988, p. 250.

${ }^{9}$ M. J. DE ALMEIDA Costa, História do direito português, Almedina, Coimbra, $3^{\mathrm{a}}$ ed., $9^{\mathrm{a}}$ reimpr., 2009, p. 190.

${ }^{10}$ P. Ferreira da Cunha, J. Aguiar e Silva e A. Lemos Soares, História do direito, Almedina, Coimbra, 2005, p. 368.

${ }^{11}$ M. CAETANO, História do direito português, Verbo, Lisboa - São Paulo, $4^{\mathrm{a}}$ ed., 2000, p. 231.

${ }^{12}$ N. J. ESPINOSA GoMeS DA SILVA, História do direito português, Fundação Calouste Gulbenkian, Lisboa, $4^{\mathrm{a}}$ ed., 2006, p. 154-55.
} 
que rompe violenta e brutalmente com o passado tradicional, a humildade perante a Criação, a consciência de que o homem pode ser ultrapassado por acontecimentos por si próprio desencadeados, a desconfiança de tudo o que não foi sancionado pela tradição. Tudo isso se consubstancia no respeito aos testemunhos dos mais idosos quando se trata de provar que um direito contestado é exercido desde tempos imemoriais ${ }^{13}$.

\subsection{FORAIS}

Foral é o diploma pelo qual uma autoridade concedia direitos e fixava deveres aos habitantes de uma povoação. Tratava, entre outras matérias, de liberdades e garantias das pessoas e bens, tributos em geral, encargos e privilégios, composições e sanções ${ }^{14}$. Nele se estabelecia também a quantidade de frutos que os vilãos deveriam pagar aos senhores das terras, os serviços que haveriam de fazer, como seriam firmes os seus contratos, quem seriam seus juízes, de que modo certos crimes seriam castigados ${ }^{15}$.

Era por meio dos forais que se instituíam os concelhos, nos quais os homens bons, em assembléia, decidiam os destinos da comunidade ${ }^{16}$. Porém, há concelhos que não tiveram foral, e há forais sem subjacente organização municipal ${ }^{17}$.

Os forais eram, normalmente, outorgados pelo rei, mas há registros de forais outorgados por senhores dentro de seus respectivos senhorios, tais como bispos, mestres de ordens militares, corporações monásticas e ricos-homens ${ }^{18}$. Daí sua classificação em forais régios e forais atribuídos por outras entidades.

São exemplos da segunda classe o foral do Porto, de 1123, concedido pelo bispo D. Hugo; o de Sernancelhe, de 1124, concedido por uma autoridade secular, D. Egas Gondesendis $^{19}$. No reinado de D. Afonso Henriques, D. Gualdim deu foral a Tomar, Pombal e Zezere. Em 1206, D. Froile Hermiges deu foral a Vila Franca de Xira; em 1216,

\footnotetext{
${ }^{13}$ R. PERnOUd, Luz sobre a idade média, Publicações Europa-América, Mira-Sintra - Mem Martins, 1997, p. $194-95$.

${ }^{14}$ Memoria que também levou accessit, e tracta do direito de correição usado nos antigos tempos, e nos modernos, e qual seja a sua natureza, Memorias de Litteratura Portugueza, t. II, Academia Real das Sciencias de Lisboa, Lisboa, 1792, p. 190.

${ }^{15}$ L. C. DE AZEVEDO, Introdução à história do direito, RT, São Paulo, $2^{\text {a }}$ ed., 2007, p. 299.

${ }^{16}$ J. R CRUZ E TUCCI e L. C. DE AZEVEDO, Lições de história do processo civil lusitano, RT e Coimbra Editora, São Paulo, 2009, p. 29.

${ }^{17}$ N. J. ESPINOSA GOMES DA SILVA, História do direito português, Fundação Calouste Gulbenkian, Lisboa, $4^{\mathrm{a}}$ ed., 2006, p. 171.

${ }^{18}$ M. CAETANO, História do direito português, Verbo, Lisboa - São Paulo, $4^{\mathrm{a}}$ ed., 2000, p. 239.

${ }^{19}$ P. Ferreira da Cunha, J. Aguiar e Silva e A. Lemos Soares, História do direito, Almedina, Coimbra, 2005 , p. 375.
} 
D. João Domingues, a Carvalhal de Ceras; em 1254, D. Martim Peres, a Vila Boa Jejua, no bispado de Guarda ${ }^{20}$. O foral de Vila do Touro foi dado pelo mestre do Templo, D. Pedro de Alvito ${ }^{21}$.

Dentre os forais régios estão os de São João da Pesqueira, Penela, Paredes, Linhares, Anciães e Santarém, outorgados por monarcas leoneses, alguns deles confirmados pelos reis de Portugal. D. Henrique e D. Teresa outorgaram os forais de Guimarães, Azurara da Beira, Tentúgal e Coimbra. ${ }^{22}$.

Os forais também se classificam em originários e confirmativos ou ampliativos. Os primeiros, que são os fundamentais, estão vinculados à origem de um concelho. Os demais eram dados a uma localidade que já possuía o seu foral originário, com o objetivo de completar, ampliar ou ratificar as disposições contidas ${ }^{23}$.

A finalidade da autoridade concedente do foral era tornar habitado um local ermo ou atrair nova mão-de-obra a um local já habitado. Para tanto, o rei, senhor ou autoridade eclesiástica, cada qual relativamente a um território de seu domínio, dirigia-se em abstrato a todos quantos quisessem se fixar em determinada localidade, mediante a aceitação das cláusulas estabelecidas pelo diploma ${ }^{24}$. Essa aceitação não constava no foral, mas era considerada um pacto inviolável, com características de um «contrato aberto» ${ }^{25}$.

Apesar da multiplicidade de forais, seu conteúdo não variava muito. Havia a tendência de os forais se subsumirem ao foral de Santarém, ou ao de Salamanca, ou ao de Ávila ${ }^{26}$. Por conseguinte, é possível agrupá-los em quatro tipos: a) foral de Santarém, concedido a Lisboa, Coimbra, Leiria, Montemor Velho, Alenquer, Torres Vedras, Povos, Almada, Vila Viçosa, Evoramonte, Monsaraz, Borba, Estremoz, Beja, Silves, Faro, Loulé, Tavira, Castromarim etc.; b) foral de Salamanca, concedido a Marialva, Moreira, Celorico da Beira, Vila Franca da Beira, Trancoso, Touro, Aguiar da Beira, Penedono, Penamacor, Castreição, Salvaterra do Extremo, Valhelhas, Proença, Linhares, Gouveia, Idanha Nova, Idanha Velha, Guarda, Felgosinho, Castelo Mendo, Santa Cruz das Naves, Freixo da Serra,

${ }^{20}$ Memoria que também levou accessit, e tracta do direito de correição usado nos antigos tempos, e nos modernos, e qual seja a sua natureza, Memorias de Litteratura Portugueza, t. II, Academia Real das Sciencias de Lisboa, Lisboa, 1792, p. 190.

${ }^{21}$ J. Veríssimo Álvares DA Silva, Sobre a forma dos juízos nos primeiros séculos da monarquia portugueza, Memorias de Litteratura Portugueza, t. VI, p. 51.

${ }^{22}$ M. J. DE AlmEIDA CosTA, História do direito português, Almedina, Coimbra, $3^{\mathrm{a}}$ ed., $9^{\mathrm{a}}$ reimpressão, 2009, p. 187.

${ }^{23}$ M. CAETANO, História do direito português, Verbo, Lisboa - São Paulo, $4^{\mathrm{a}}$ ed., 2000, p. 236.

${ }^{24}$ M. J. DE Almeida Costa, História do direito português, Almedina, Coimbra, $3^{\mathrm{a}}$ ed., $9^{\mathrm{a}}$ reimpressão, 2009, p. 188.

${ }^{25}$ M. CAETANo, História do direito português, Verbo, Lisboa - São Paulo, $4^{\mathrm{a}}$ ed., 2000, p. 236.

${ }^{26}$ N. J. ESPINOSA GOMES DA SILVA, História do direito português, Fundação Calouste Gulbenkian, 2006, 4 ed., p. 173. 
Urros, Numão, Mós, Valença, Monção, Viana etc.; c) foral de Ávila, concedido a Évora, Elvas, Montemor Novo, Portel, Terena, Seda, Gravão, Mértola, Alter, Aviz, Crato, Marvão, Corouche, Abrantes, Alcacer, Palmela, Cezimbra, Arouche, São Vicente da Beira, Castelo Branco, Alpedrinha, Sortelha, Sarzedas, Covilhã, Pinhel etc.; e d) forais que não se subsumem a qualquer dos tipos precedentes, ou porque concedidos a locais em que os costumes estavam por demais radicados para que a população se sujeitasse a algum dos três tipos principais de forais, ou porque circunstâncias especiais determinavam algum aspecto singular de organização; por exemplo, a Melgaço, D. Afonso I concedeu o foral de Ribadavia na Galícia; e a Chaves e outros concelhos, D. Afonso III concedeu o foral de Zamora $^{27}$.

\subsection{FOROS}

Foro ou estatuto municipal é a compilação dos costumes jurídicos de determinado concelho ${ }^{28}$, reduzidas a escrito, especialmente na segunda metade do século XIII e nos inícios do século XIV ${ }^{29}$.

Distinguem-se os forais dos foros: enquanto nos primeiros predominam normas de direito público (relações dos habitantes ou vizinhos do respectivo concelho com o Estado ou senhores do território), nos segundos predominam normas de direito privado; enquanto os primeiros são mais rudimentares, os segundos já contêm mais extensas disposições, e muitas vezes se dividem em artigos; e enquanto os primeiros são mais antigos, e em alguns casos conferidos ainda durante o domínio leonês, os segundos datam dos séculos XIII e XIV ${ }^{30}$.

Já se viu, no exame dos costumes medievais, o quanto os povos eram firmemente arraigados aos seus costumes, cuja autoridade era expressamente reconhecida pelo poder central. D. Sancho I, numa doação de 1191, repetindo S. Isidoro de Sevilha, diz: Qum consuetudine, que pro lege suscipitur. Ao impor-se o direito escrito, que surge, na maior parte das vezes, para contrariar formas consuetudinárias e corrigi-las, quando não

\footnotetext{
${ }^{27}$ A. Herculano, História de Portugal, t. 7, Livrarias Aillaud \& Bertand - Livraria Francisco Alves, Paris Lisboa - Rio - São Paulo - Belo Horizonte, $8^{\text {a }}$ ed., p. 177-79.

${ }^{28}$ P. Ferreira da Cunha, J. Aguiar e Silva e A. Lemos SoAres, História do direito, Almedina, Coimbra, 2005, p. 370-71.

${ }^{29}$ N. J. EsPINOSA GOMES DA SILVA, História do direito português, Fundação Calouste Gulbenkian, $4^{\mathrm{a}}$ ed., 2006, p. 170.

${ }^{30}$ P. Ferreira da Cunha, J. Aguiar e Silva e A. Lemos SoAres, História do direito, Almedina, Coimbra, 2005, p. 372-73.
} 
para fortalecer o poder real, há o fenômeno da compilação do direito consuetudinário, o que resultará nos foros que hoje conhecemos ${ }^{31}$.

$\mathrm{Na}$ Espanha, tanto os forais quanto os foros são designados pela palavra «fuero». Entretanto, ao se referirem aos primeiros, os autores acrescentam o adjetivo «breve», e aos segundos, «extenso» ${ }^{32}$.

\subsection{CÓDIGO VISIGÓTICO}

Até a independência, muito embora houvesse a proeminência do costume e dos forais, estava em vigor no território português o Código Visigótico. E a autonomia política de Portugal não implicou imediata autonomia no campo do direito, pois se manteve o sistema jurídico herdado de Castela ${ }^{33}$.

Há dois documentos do conde D. Henrique e de D. Teresa que mencionam expressamente a legislação dos godos, uma doação a Alberto Tibao e o foral por eles outorgado a Soure. No primeiro, consta «Magnus est titulus donationis in quo nemo potest autum largitatis irrumpere ... ut in Gothorum Legibus continetur». No segundo, «qui vocem vestra pulsaverit ilud castrum pariat in quadruplum, et Regiae quomodo líber judicum praecipiat» ${ }^{34}$.

Com efeito, durante todo o século XII, ou seja, após a independência, é ainda freqüente em documentos a invocação do Código Visigótico, neles designado como lex gothorum, lex, forum iudicum, liber iudicum, e liber iudicialis, o que tanto pode significar a efetiva vigência de suas normas quanto a simples persistência de fórmulas rotineiras de juízes e tabeliães. De qualquer forma, até então, esse era o único corpo de legislação capaz de servir de lastro jurídico para a nação recém-fundada ${ }^{35}$; e na corte, as

\footnotetext{
${ }^{31}$ N. J. EspinOSA Gomes DA SILVA, História do direito português, Fundação Calouste Gulbenkian, $4^{\mathrm{a}}$ ed., 2006, p. 167-70.

${ }^{32}$ P. Ferreira da Cunha, J. Aguiar e Silva e A. Lemos SoAres, História do direito, Almedina, Coimbra, 2005, p. 371.

${ }^{33}$ M. J. DE AlmeIDA CostA, História do direito português, Almedina, Coimbra, $3^{\mathrm{a}}$ ed., $9^{\mathrm{a}}$ reimpressão, 2009, p. 174-75.

${ }^{34}$ J. VERÍSSIMO ÁLVARES DA SILVA, Memoria sobre a forma dos juízos nos primeiros séculos da monarquia portugueza, Memorias de Litteratura Portugueza, t. VI, Lisboa, 1796, p. 62.

${ }^{35}$ M. J. DE AlmeIda Costa, História do direito português, Almedina, Coimbra, $3^{\mathrm{a}}$ ed., $9^{\mathrm{a}}$ reimpressão, 2009, p. $183-84$
} 
evidências são no sentido de que era mais conhecido e observado, tanto que D. Afonso II o invocou para proibir as leis de Soeiro Gomes, prior dos dominicanos ${ }^{36}$.

O Código Visigótico, ou «Fuero Juzgo», promulgado por Rescevindo em 654, contém normas oriundas tanto dos antigos costumes germânicos quanto do direito romano e canônico (Codex Euriciano, Lex Romana Visigothorum, cânones dos concílios e ensinamentos de S. Isidoro de Sevilha) ${ }^{37}$.

É dividido em doze livros, que compreendem cinqüenta e quatro títulos e quinhentos e oitenta e cinco artigos.

Quanto ao juiz, o «Fuero Juzgo» (Liv. I, Tít. I, Lei VII) determina que deve ser pronto e ágil ao indagar, firme ao prevenir, não se mostrar ansioso para decidir, moderado ao castigar e freqüente em perdoar ${ }^{38}$. Estabelece tanto juízes como conciliadores ou árbitros, estes últimos impedidos de julgar feitos criminais ${ }^{39}$.

Preocupado com que, a partir de então, não se observasse qualquer outra legislação, Rescesvindo ordenou, sob pena de multa, que fossem queimados ou inutilizados todos os demais livros que continham leis revogadas (Liv. II, Tít. I, Lei IX) ${ }^{40}$.

E para que o «Fuero Juzgo» fosse bem propagado, fixou-se em doze soldos o preço máximo de cada cópia manuscrita, sob pena de cem açoites, aplicados tanto ao comprador quanto ao vendedor ${ }^{41}$. Não obstante, era conhecido apenas por juízes mais cultos e clérigos mais ilustrados, a ponto de o fato de um juiz possuir o Código ser tão invulgar que merecia ser registrado: M. CAETANO menciona uma doação de 1110, referente

\footnotetext{
${ }^{36}$ M. CAETANo, História do direito português, $4^{\mathrm{a}}$ ed., 2000, Lisboa - São Paulo, Verbo, p. 240. O episódio com Soeiro Gomes, prior dos dominicanos, é bastante revelador do conceito que D. Afonso II fazia da autoridade régia. D. Pedro, bispo de Coimbra, que estava louco, autorizou os dominicanos a missionarem por sua diocese e concederem remissão dos pecados e indulgências àqueles atraídos às suas pregações; e a Frei Soeiro Gomes concedeu também licença e poder para corrigir excessos e compelir à emenda quaisquer delitos. Frei Soeiro pretendeu, com fundamento em tal licença, impor penas temporais aos culpados, contra quem a Igreja tinha até então apenas a censura canônica. D. Afonso II, indignado, publicou uma lei pela qual os concelhos, alcaides e oficiais públicos foram severamente proibidos de aceitar os decretos de Soeiro Gomes. A pena imposta a quem quisesse dar validade a esses decretos era de mil morabitinos; e aos oficiais públicos, perda do cargo, confisco de bens e castigo corporal (A. HeRCUlANO, História de Portugal, t. IV, Livrarias Aillaud \& Bertand - Livraria Francisco Alves, Paris - Lisboa - Rio - São Paulo - Belo Horizonte, $8^{\mathrm{a}}$ ed., p. 132-36).

${ }^{37}$ L. C. DE AZEVEDO, Introdução à história do direito, RT, São Paulo, 2 a ed., 2007, p. 92.

${ }^{38}$ L. C. DE AZEVEDO, Introdução à história do direito, $2^{\mathrm{a}}$ ed., 2007, São Paulo, RT, p. 92.

${ }^{39}$ L. C. DE AZEVEDO, O direito de ser citado, 1980, São Paulo, FIEO e Resenha Universitária (co-edição), p. 193-94.

${ }^{40}$ L. C. DE AZEVEDO, O direito de ser citado, FIEO e Resenha Universitária (co-edição), São Paulo, 1980, p. 191.

${ }^{41}$ C. MENDES DE AlMEIDA, Codigo philipino ou ordenações e leis do reino de Portugal recopiladas por elrey d. Phipippe I, t. I, Typographia do Instituto Philomathico, Rio, 14 a ed., 1870, edição fac-similar do Senado Federal, 2004, Brasília, p. XIII.
} 
a bens situados perto de Vila do Conde, na qual um dos confirmantes é identificado como Petrus iudex aba qui tenet Lex Godorum ${ }^{42}$.

Segundo J. A. Anes DuARTE NogueIRA, a fixação da tradição gótica no campo do direito, antes do século XII, deveu-se a alguns centros monásticos que concentravam a parte mais substancial da elite cultural da época, entre eles os mosteiros de Lorvão, Vacariça, Leça e Guimarães ${ }^{43}$.

\subsection{SETE PARTIDAS}

As Sete Partidas, leis castelhanas promulgadas por volta de 1265, por D. Afonso X, o Sábio, rei de Leão e Castela, foram traduzidas para o português por ordem de seu neto, D. Diniz de Portugal (1279 -1325). Essa legislação tem profunda influência do direito romano. Havia exemplares dessa tradução na biblioteca do convento de Alcobaça e na livraria do convento de Santo Antonio da Merceana ${ }^{44}$.

As Sete Partidas foram o veículo de introdução do direito comum em Portugal $^{45}$, pois serviram como fonte do direito subsidiária, na falta de leis pátrias ${ }^{46}$.

Nas Cortes de Elvas, em 1361, os povos se queixaram ao rei D. Pedro I (1357 -1367) da aplicação das Sete Partidas em Portugal, conforme o art. 24 da respectiva Concórdia:

«que as Justiças muitas vezes não queriam guardar o Direito Canônico, que era feito pelo Padre Santo que tinha as vezes de Jesuz Cristo, e era mais razão de o guardarem em todo os Senhorio pela dita razão, de que as Sete Partidas feitas por ElRei de Castella, ao qual o Reino de Portugal não era sugeito, mas bem izento de todo» ${ }^{47}$.

\footnotetext{
${ }^{42}$ M. CAETANO, História do direito português, $4^{\mathrm{a}}$ ed., 2000, Lisboa - São Paulo, Verbo, p. 240.

${ }^{43}$ J. A. Anes DuArte NogueIRA, Sociedade e direito em Portugal na idade média, Suplemento da Revista da Faculdade de Direito da Universidade de Lisboa, Lisboa, 1994, p. 411-12. Segundo cálculos desse autor, na região de Leça teria havido 21 mestres: na de Vacariça, 6; na de Lorvão, 5; na de Guimarães, 3; na de Vale de Cambra, 3; na de Pedroso, 3; na de Sever do Vouga, 3; na de Braga, 2; na de Arouca, 2; na de Lafões, 1; e na de Tarouquela, 1 (ob. cit., p. 41).

${ }^{44}$ J. A. DE FIGUEIREDO, Memoria sobre qual foi a época certa da introducção do Direito de Justiniano em Portugal, o modo de sua introducção, e os gráos de authoridade, que entre nós adquirio, Memorias da Litteratura Portugueza, t. I, Lisboa, 1792, p. 283-84.

${ }^{45}$ J. R. CRUZ E TUCCI e L. C. DE AZEVEDo, Lições de história do processo civil lusitano, RT, São Paulo, 2009, p. 32.

46 J. A. DE FigueIREDo, Memoria sobre qual foi a época certa da introducção do Direito de Justiniano em Portugal, o modo de sua introducção, e os gráos de authoridade, que entre nós adquirio, Memorias da Litteratura Portugueza, t. I, Lisboa, 1792, p. 286.

${ }^{47}$ J. A. DE FIGUEIREDO, Memoria sobre qual foi a época certa da introducção do Direito de Justiniano em Portugal, o modo de sua introducção, e os gráos de authoridade, que entre nós adquirio, Memorias da Litteratura Portugueza, t. I, Lisboa, 1792, p. 285.
} 
Esse texto revela o grande prestígio do direito canônico, a razão desse prestígio, a efetiva aplicação das Sete Partidas em território português, e a repulsa dos povos por essa aplicação, uma vez que ela poderia indicar certa sujeição do reino a Castela, o que feria os brios da nação independente.

A autoridade das Sete Partidas acabou em Portugal durante o reinado de D. Pedro I, graças à crescente influência do direito de Justiniano e do Decreto de Graciano ${ }^{48}$.

\subsection{DIREITO ROMANO}

A partir do século XII, o pólo cultural, permanecendo ainda no meio eclesiástico, desloca-se dos mosteiros para as escolas catedrais, e dessas escolas sairão os primeiros magistri com potencial ligação com o direito romano-canônico ${ }^{49}$.

O direito romano, quanto à sua evolução interna, é dividido em três fases: a) a do direito quiritário, que vai da fundação de Roma até a Lei das XII Tábuas; b) a do ius gentium, em ius honorarium e cognitio extra ordinem; e c) a pós-clássica, que começa com Diocleciano e se encerra com Justiniano ${ }^{50}$. Sempre que se fala no direito romano como fonte jurídica portuguesa na idade média, a referência é ao direito de Justiniano.

Não obstante a opinião de T. A. DE Villa-Nova Portugal, de que o estabelecimento do direito romano em Portugal se deu no reinado de D. João I, sendo o reinado de D. Diniz apenas preparação para a mudança ${ }^{51}$; e a de J. A DE FIGUEIREDO, que faz remontar a introdução do direito romano ao reinado de D. Afonso Henriques ${ }^{52}$; o apogeu da recepção do direito comum ocorre no reinado de D. Diniz (1279-1325), durante

\footnotetext{
${ }^{48}$ J. A. DE FIGUEIREDo, Memoria sobre qual foi a época certa da introducção do Direito de Justiniano em Portugal, o modo de sua introducção, e os gráos de authoridade, que entre nós adquirio, Memorias da Litteratura Portugueza, t. I, Lisboa, 1792, p. 290.

49 J. A. ANes DuARte NogueIRA, Sociedade e direito em Portugal na idade média, Suplemento da Revista da Faculdade de Direito da Universidade de Lisboa, Lisboa, 1994, p. 415.

${ }^{50}$ A. CORREIA e G. SCIASCIA, Manual de direito romano, v. I, Saraiva, São Paulo, 1949, p. 8-9.

${ }^{51}$ T. A. DE VILla-Nova PortugAl, Memoria ao programa: qual seja a epocha fixa da introducção do direito romano em Portugal, e o grao de authoridade que elle teve nos diversos tempos, Memorias de Litteratura Portugueza, t. V, p. 377.

52 J. A. DE FIGUEIREDO, Memoria sobre qual foi a época certa da introducção do Direito de Justiniano em Portugal, o modo de sua introducção, e os gráos de authoridade, que entre nós adquirio, Memorias da Litteratura Portugueza, t. I, Lisboa, 1792, p. 330.
} 
o qual são traduzidas as «Flores de Las Leyes», do mestre $\mathrm{Jacob}^{53}$, e as «Siete Partidas», de D. Afonso, o Sábio, bem como é fundado, em $1^{\circ}$ de março de 1290, o Studium generale ${ }^{54}$.

Mas, mesmo antes desse período, há alguns exemplos de que o direito romano já exercia certa influência, como quando, nas Cortes de Coimbra, de 1211, D. Afonso II estabeleceu que, se alguém fosse condenado à morte ou à amputação de membro, a sentença ficasse suspensa por vinte dias, depois dos quais seria executada, se não fosse revogada. Trata-se de disposição do Código de Justiniano, com a única diferença de que, neste, a suspensão era de trinta dias ${ }^{55}$.

Aliás, essa influência era muito natural, pois, como se verá mais adiante, desde os tempos de D. Afonso Henriques os monarcas nomearam jurisconsultos para o seu conselho.

Porém, pode-se ter por certo que, no início da monarquia portuguesa, essa influência era ainda bastante tímida, pois a população estava ainda bastante apegada ao direito consuetudinário e foraleiro, e à herança jurídica visigótica. A partir do reinado de D. Diniz, ao contrário, o direito de Justiniano se afirmou com autoridade crescente, o que perdurará até meados do século XVIII.

O direito de Justiniano tornou-se um manancial inesgotável de soluções concretas para as questões que se apresentavam aos tribunais, como fonte subsidiária, pois o direito consuetudinário poderia mostrar-se ultrapassado e a legislação portuguesa era incipiente ainda ${ }^{56}$.

Em 18 de abril de 1426, uma carta régia de D. João I (1385 - 1433) atribuiu à Glosa de Acúrsio e aos Comentários de Bártolo a primazia sobre as opiniões dos demais doutrinadores ${ }^{57}$.

\footnotetext{
${ }^{53}$ Esse livro é considerado o primeiro compêndio de direito processual civil que se publicou na Península Ibérica, conforme L. C. DE AZEVEDo e MOACYR LOBO DA COSTA, Estudos de história do processo recursos, FIEO e Joen Editora (co-edição), São Paulo, 1996, p. 146.

${ }^{54}$ J. R. CRUZ E TUCCI e L. C. DE AZEVEDO, Lições de história do processo civil lusitano, São Paulo, 2009, RT, p. 54.

55 J. A. DE FIGUEIREDO, Memoria sobre qual foi a época certa da introducção do Direito de Justiniano em Portugal, o modo de sua introducção, e os gráos de authoridade, que entre nós adquirio, Memorias da Litteratura Portugueza, t. I, Lisboa, 1792, p. 274-75.

${ }^{56}$ J. R. CRUZ E TUCCI, Precedente judicial como fonte do direito, RT, São Paulo, 2004, p. 125.

${ }^{57}$ J. R. CRUZ E TuCCI, Precedente judicial como fonte do direito, RT, São Paulo, 2004, p. 129.
} 


\subsection{CONCÍLIOS}

Concílios, no período visigótico, eram assembléias de que participavam altos dignitários eclesiásticos, que representavam as sés episcopais, o monarca, nobres e membros do palatinado ${ }^{58}$.

Os concílios se classificam em ecumênicos, os que abrangem toda a Igreja; nacionais, os restritos a um país; e provinciais, os relativos a uma região ou arquidiocese ${ }^{59}$.

Na maior parte da idade média, por causa da dificuldade das comunicações, entre outros fatores, a Igreja católica era menos centralizada do que na época moderna, o que dava especial relevo aos concílios, em especial os nacionais ${ }^{60}$. Só no século XI, no reinado de Afonso VI, é que as igrejas hispânicas ficaram mais diretamente sujeitas a Roma $^{61}$.

Os concílios, embora em princípio se destinassem à resolução de problemas de natureza eclesiástica, muitas vezes alargavam sua competência até assuntos de natureza administrativa, civil e política, chegando mesmo a estabelecer normas para a eleição e deposição do soberano e a decidir causas de particulares ${ }^{62}$.

Diversas normas jurídicas surgiram em concílios. No de Toledo, em 638, decretou-se que ninguém seria acusado por outro ou supliciado sem que o acusador se apresentasse; no de 683, realizado na mesma cidade, estabeleceu-se o chamado habeas corpus visigótico, pelo qual nenhuma pessoa vinculada ao rei por juramento de fidelidade, salvo culpa evidente, poderia ser presa, acorrentada, desapossada de seus bens ou torturada para obter-se a confissão, sem que antes fosse apresentada à assembléia, garantindo-se tal procedimento também às pessoas livres, ainda que de condição inferior ${ }^{63}$.

Dois concílios apresentam especial interesse para a história do direito português: o de Coiança, convocado por Fernando I, em 1050; e o de Oviedo, em 1115, reunido ao tempo de D. Urraca. O cap. VIII das leis de Coiança - há controvérsia se esse texto é original - refere-se expressamente à sua aplicabilidade a Portugal; e essas leis

\footnotetext{
${ }^{58}$ L. C. DE AZEVEDO, Introdução à história do direito, RT, São Paulo, 2007, $2^{\mathrm{a}}$ ed., p. 91.

${ }^{59}$ M. CAETANO, História do direito português, Verbo, Lisboa - São Paulo, $4^{\mathrm{a}}$ ed., 2000, p. 241.

${ }^{60}$ M. J. DE AlmeIDA COSTA, História do direito português, Almedina, Coimbra, $3^{\mathrm{a}}$ ed., $9^{\mathrm{a}}$ reimpressão, 2009, p. 140 .

${ }^{61}$ N. J. EspinOSA GOMES DA SILVA, História do direito português, Fundação Calouste Gulbenkian, $4^{\mathrm{a}}$ ed. 2006, p. 179.

${ }^{62}$ L. C. DE AZEVEDO, O direito de ser citado, FIEO e Resenha Universitária (co-edição), São Paulo, 1980, p. 156 e 189

${ }^{63}$ L. C. DE AZEVEDO, Introdução à história do direito, RT, São Paulo, 2007, 2ª ed., p. 91.
} 
foram copiadas no Livro Preto da Sé de Coimbra. Quanto às leis de Oviedo, foram juradas e confirmadas por D. Teresa e D. Afonso Henriques ${ }^{64}$.

\subsection{DIREITO CANÔNICO}

Ao contrário do direito romano, que, como se viu acima, foi introduzido gradualmente em Portugal entre o final do século XIII e o início do século XIV, o direito canônico, por conta da influência da Igreja, já era observado desde muito antes da independência.

A história do direito canônico se divide em quatro períodos: a) o inicial, que compreende as primeiras fontes e coleções canônicas e se estende do século I ao XI; b) o da estabilização, nos séculos XI e XII; c) o da consolidação, dos séculos XIII ao XV; d) e o da renovação, a partir do século $\mathrm{XVI}^{65}$.

Há um registro no livro Fidei, da Sé de Braga, de que Afonso VI, rei de Leão e Castela de 1072 a 1109, obteve de legados apostólicos, em um sínodo, que se guardassem em seus reinos os Santos Cânones ${ }^{66}$.

Com efeito, no Livro das Doações do Mosteiro de Paço de Souza e em diversos documentos dos cartórios do Mosteiro de S. Bento d'Ave Maria do Porto e do Mosteiro de Pendorada, há citações aos Santos Cânones com datas próximas ao reinado de Afonso VI de Leão e Castela ${ }^{67}$.

Em 1140, surge a obra Concordia discordantium canonum, do monge João Graciano, mais conhecida como Decreto de Graciano. Seu autor teve objetivo de harmonizar e esclarecer preceitos canônicos de diversa procedência, agrupando-os de forma sistemática. Em 1234, o papa Gregório IX promulga as Decretales extra decretum Graciani vagantes, conhecidas como Decretais, organizadas por S. Raimundo de Peñafort em cinco livros. Em 1298, o papa Bonifácio VIII publicou o Livro Sexto, complementando as Decretais com normas posteriores. E entre 1311 e 1312 houve o Concílio de Viena, na França, cujos cânones foram acrescentados de Decretais próprias por ordem do papa

\footnotetext{
${ }^{64}$ N. J. EspinOSA Gomes DA SILVA, História do direito português, Fundação Calouste Gulbenkian, $4^{\mathrm{a}}$ ed., 2006, p. 175.

${ }^{65}$ J. R. CRUZ E TUCCI e L. C. DE AZEVEDO, Lições de processo civil canônico, RT, São Paulo, 2001, p. 22.

${ }^{66}$ J. P. RIBEIRO, Qual seja a época da introducção do direito das decretaes em Portugal, e o influxo que o mesmo teve na legislação portuguesa, Memorias de Litteratura Portugueza, t. VI, Lisboa, 1796, p. 6.

${ }^{67}$ J. P. RIBEIRO, Qual seja a época da introducção do direito das decretaes em Portugal, e o influxo que o mesmo teve na legislação portuguesa, Memorias de Litteratura Portugueza, t. VI, Lisboa, 1796, p. 7.
} 
Clemente V, resultando na obra que se tornou conhecida por Clementinas, muito embora, por causa da morte desse pontífice, só tenha sido aprovada por seu sucessor, João XII, em $1317^{68}$.

Momento importante para o direito em Portugal foram as Cortes de Coimbra, de 1211, em que D. Afonso II (1211 - 1223) estabeleceu, na Lei 1 que as leis contrárias à Santa Igreja de Roma ou a seus direitos não valessem; na Lei 13, corroborada pelo Lei 16, a imunidade eclesiástica real e pessoa; na Lei 21, a liberdade dos matrimônios ${ }^{69}$; na Lei 25 , a observância das leis canônicas sobre judeus e mouros; e na Lei 12, o foro dos clérigos ${ }^{70}$.

Ainda no reinado de D. Afonso II foram freqüentes os rescritos ${ }^{71}$ pontifícios dirigidos a Portugal. Num deles, o papa Inocêncio III deu, por juízes delegados, sentença contra os cidadãos do Porto que haviam injuriado o bispo daquela diocese; noutro, se ordena ao bispo, ao deão ${ }^{72}$ e ao chantre ${ }^{73}$ do Porto que conheçam de um contrato acusado de usurário ${ }^{74}$.

No reinado de D. Sancho II (1223-1245), o papa Gregório IX, em um rescrito dirigido ao bispo de Lisboa, determinou a observância das leis canônicas sobre os judeus $^{75}$.

A autoridade eclesiástica se estendeu a assuntos alheios a sua jurisdição durante o reinado de D. Afonso III (1248 - 1279, regente a partir de 1245), que assumiu o trono após a deposição de D. Sancho II pelo papa ${ }^{76}$.

\footnotetext{
${ }^{68}$ M. J. DE AlmeIDA CoSTA, História do direito português, Almedina, Coimbra, $3^{\mathrm{a}}$ ed., $9^{\mathrm{a}}$ reimpressão, 2009, p. 247-48.

${ }^{69} \mathrm{O}$ pai de D. Afonso II, D. Sancho I, segundo acusação do bispo de Coimbra, constrangia as viúvas a se casarem contra a vontade (A. Herculano, História de Portugal, v. 4, p. 10).

${ }^{70}$ J. P. RiBeIRo, Qual seja a época da introducção do direito das decretaes em Portugal, e o influxo que o mesmo teve na legislação portuguesa, Memorias de Litteratura Portugueza, t. VI, Lisboa, 1796, p. 9.

${ }^{71} \mathrm{O}$ atual Código de Direito Canônico, promulgado em 25 de janeiro de 1983, reafirmando tradição imemorial da Igreja, em seu Cân. 59, § 1., define que «Por rescrito entende-se o ato administrativo baixado por escrito pela competente autoridade executiva, mediante o qual, por sua própria natureza, se concede privilégio, dispensa ou outra graça, a pedido de alguém». J. HORTAL, em comentário a esse cânon, afirma que rescrito, etimologicamente, do lat. re-scriptum, significa resposta, sendo dado sempre por escrito, opondo-se aos vivae voci oracula, isto é, decisões comunicadas por palavras (Santa Sé, Código de Direito Canônico, trad. CNBB, notas e comentários J. HoRTAL, Loyola, São Paulo, $3^{\text {a }}$ ed., 2003, p. 40).

72 Título de dignidade eclesiástica inferior ao bispo ou arcebispo e que preside ao cabido.

${ }^{73}$ Dignidade eclesiástica que numa sé ou colegiada preside o coro.

${ }^{74}$ J. P. RIBEIRO, Qual seja a época da introducção do direito das decretaes em Portugal, e o influxo que o mesmo teve na legislação portuguesa, Memorias de Litteratura Portugueza, t. VI, Lisboa, 1796, p. 9-10.

${ }^{75} \mathrm{~J}$. P. RIBEIRO, Qual seja a época da introducção do direito das decretaes em Portugal, e o influxo que o mesmo teve na legislação portuguesa, Memorias de Litteratura Portugueza, t. VI, Lisboa, 1796, p. 10.

${ }^{76}$ J. P. RIBEIRO, Qual seja a época da introducção do direito das decretaes em Portugal, e o influxo que o mesmo teve na legislação portuguesa, Memorias de Litteratura Portugueza, t. VI, Lisboa, 1796, p. 11.
} 
Até D. Diniz (1279 - 1325), o único óbice à exata observância do direito canônico em Portugal era o seu desconhecimento, pois era necessário que os portugueses saíssem do reino para aprendê-lo. Com a criação, nesse reinado, da Universidade de Coimbra, cujos estatutos previam as cadeiras de Decreto e Decretais, tal óbice foi removido $^{77}$.

Referindo-se ao reinado de D. Diniz, J. Veríssimo Álvares DA SILVA afirma que o Direito Canônico, que já tinha então muito uso, «encheu tudo de apelações ${ }^{78}$.

Os leigos eram sujeitos aos tribunais eclesiásticos em razão da matéria, ou seja, em tudo o que pudesse resultar em pecado; e os clérigos, em razão da pessoa, porque gozavam de foro eclesiástico ${ }^{79}$. E o juiz eclesiástico, mesmo nas causae saeculares, aplicava o direito canônico, não o direito romano ${ }^{80}$.

Nos tribunais civis, a aplicação do direito canônico decorria da já mencionada Lei de D. Afonso II promulgada nas Cortes de $1211^{81}$. Além disso, foram muitíssimas as leis portuguesas inspiradas no direito canônico, como revela pesquisa de $\mathrm{J}$. P. RibEIRO, bastando lembrar, como exemplo, que as Ordenações Afonsinas foram divididas em cinco livros à imitação das Decretais ${ }^{82}$.

Enfim, a influência do direito canônico na legislação secular pode ser resumido na frase jus canonicum et civile sunt adeo connexa, ut unum sine altero non intellegi potest ${ }^{83}$.

\subsection{CONCÓRDIAS E CONCORDATAS}

Visavam ambas ao reconhecimento recíproco de direitos e obrigações entre o rei e a Igreja. As concórdias eram celebradas com o clero nacional; as concordatas, com o papa.

\footnotetext{
77 J. P. RIBEIRO, Qual seja a época da introducção do direito das decretaes em Portugal, e o influxo que o mesmo teve na legislação portuguesa, Memorias de Litteratura Portugueza, t. VI, Lisboa, 1796, p. 12.

${ }^{78}$ J. VERÍSSIMO ÁlVARES DA SILVA, Memoria sobre a forma dos juízos nos primeiros séculos da monarquia portugueza, Memorias de Litteratura Portugueza, t. VI, Lisboa, 1796, p. 70.

${ }^{79}$ M. CAETANO, História do direito português, $4^{\mathrm{a}}$ ed., 2000, Lisboa - São Paulo, Verbo, p. 241.

${ }^{80}$ F. WIEACKER, História do direito privado moderno, Fundação Calouste Gulbenkian, Lisboa, $3^{\text {a }}$ ed., p. 74.

${ }^{81}$ N. J. EsPinOSA Gomes DA SILVA, História do direito português, Fundação Calouste Gulbenkian, $4^{\mathrm{a}}$ ed., 2006, p. 185.

82 J. P. RIBEIRO, Qual seja a época da introducção do direito das decretaes em Portugal, e o influxo que o mesmo teve na legislação portuguesa, Memorias de Litteratura Portugueza, t. VI, Lisboa, 1796, p. 15-19.

${ }^{83}$ F. WIEACKER, História do direito privado moderno, Fundação Calouste Gulbenkian, Lisboa, $3^{\mathrm{a}}$ ed., p. 77.
} 
As concórdias mais antigas datam dos reinados de D. Sancho I, D. Afonso II e D. Sancho II $^{84}$.

Em 1238, pressionado por Roma para corrigir as desordens que anos depois o levaram a perder o trono, D. Sancho II propôs uma concordata ao papa Gregório IX, na qual ficaria estabelecido que as causas cíveis entre seculares e clérigos seriam julgadas conjuntamente pelo vigário do bispo e pelo juiz civil; entretanto, o papa não aprovou essa concordata $^{85}$.

\subsection{PRECEDENTES JUDICIAIS}

Impossível ignorar também o papel dos precedentes judiciais enquanto fontes do direito no período estudado. Eles eram designados na legislação pela palavra façanhas.

As façanhas, segundo J. A. DE FiguEIREDO, eram

«juízos ou sentenças, que se dessem principalmente em casos, em que as Leis do Paiz não dessem providencia, e que fossem duvidosos ou omissos. E como taes Sentenças podiam ser dadas pelos Reis, ou pelos seus Magistrados, ou por Arbitros, que a prazer das partes se nomeassem, e escolhessem ${ }^{86}$.

O monarca português tinha a prerrogativa exclusiva de dar a interpretação autêntica das leis, seja pela promulgação de lei interpretativa, seja «em relação» ${ }^{87}$, isto é, quando proferia julgamento presidindo as sessões da Casa de Suplicação ou da Casa do Cível $^{88}$. Evidentemente, a interpretação de lei «em relação» pelo rei constituía o precedente judicial mais qualificado a época em exame. Após o período estudado nesta dissertação, D. Manuel I (1495 - 1512) outorgou, em parte, essa prerrogativa ao tribunal superior do reino, a Casa de Suplicação, reservando para si apenas aqueles casos que o regedor daquele tribunal entendesse que deveriam ser submetidos à apreciação régia, procedimento que daria origem aos Livro dos Assentos da Relação ${ }^{89}$.

\footnotetext{
${ }^{84}$ N. J. EspinOsa Gomes DA SILVA, História do direito português, Fundação Calouste Gulbenkian, $4^{\mathrm{a}}$ ed., 2006, p. 177.

${ }^{85}$ A. Herculano, História de Portugal, v. 4, p. 280-81.

86 J. A. DE FIGUEIREDO, Memoria sobre qual seja o verdadeiro sentido da palavra Façanhas, que expressamente se achão revogadas em algumas leis, e cartas de doações e confirmações antigas, como ainda se acha na Ord. Liv. 2 tit. 35 § 6, Memorias de Litteratura Portugueza, t. I, Lisboa, 1792, p. 66-67.

${ }^{87}$ Em um tribunal de segunda instância que julga apelações ou agravos.

${ }^{88}$ J. R. CRUZ E TuCCI, Precedente judicial como fonte do direito, RT, São Paulo, 2004, p. 131.

${ }^{89}$ J. R. CRUZ E TUCCI, Precedente judicial como fonte do direito, RT, São Paulo, 2004, p. 133.
} 
Outra espécie de precedente judicial no período estudado eram os estilos da Corte, definidos como ius quoddam non scriptum, usibus introductum, ab uno iudice stillatum. Estilo e costume eram fontes do direito não escritas introduzidas pelo uso, mas, enquanto os estilos eram introduzidos por juiz, o costume decorria da reiteração de determinada prática por um grupo social ${ }^{90}$.

\subsection{LEIS GERAIS}

As Leis Gerais encontram-se, em sua maioria, compiladas no Livro das Leis e Posturas. As mais antigas datam de 1211, do reinado de D. Afonso II ${ }^{91}$. Também há leis gerais nas Ordenações de D. Duarte, compilação que teria pertencido à biblioteca desse monarca $^{92}$.

Algumas dessas Leis Gerais se referem diretamente à organização judiciária e à administração da justiça:

De D. Afonso III: a que fixou o número máximo de testemunhas em trinta; a que proibiu o testemunho de mulheres, salvo sobre fato ocorrido em fornos, moinhos, lavandarias e banhos; a que determinou que se recebesse a apelação da parte que a interpusesse em até nove dias, ou, se a apelação fosse feita no lugar em que o rei estava, devia ser interposta dentro em três dias, e processada em até nove ${ }^{93}$.

De D. Diniz: a da Pontaria, que ameaça de morte os alcaides, comendadores, meirinhos, alvazis juízes e justiças do reino que não fizerem justiça ${ }^{94}$; a que determinou aos juízes que dessem agravo até nove dias; e que o oficial de justiça que se desonestasse com pessoa que perante ele requeresse fosse castrado 95 ; a que mandou que as

\footnotetext{
${ }^{90}$ N. J. EspinOsa Gomes DA SILVA, História do direito português, Fundação Calouste Gulbenkian, $4^{\mathrm{a}}$ ed., 2006, p. 377.

${ }^{91}$ L. C. DE AZEVEDO, Introdução à história do direito, RT, São Paulo, 2007, 2a ed., p. 91.

${ }^{92}$ N. J. ESPINOSA GOMES DA SILVA, História do direito português, Fundação Calouste Gulbenkian, $4^{\mathrm{a}}$ ed., 2006, p. 287.

93 J. VERÍSSIMO ÁlVARES DA SILVA, Memoria sobre a forma dos juízos nos primeiros séculos da monarquia portugueza, Memorias de Litteratura Portugueza, t. VI, Lisboa, 1796, p. 67. Essa lei, que teria sido passada nas Cortes de Leiria, em 1254, ou nas Cortes de Coimbra, em 1261, é reproduzida por L. C. DE AZEVEDO e M. LOBO DA COSTA em Estudos de história do processo, FIEO e Joen Editora (co-edição), São Paulo, 1996, p. 80 .

${ }_{94}$ Reproduzida por L. C. DE AZEVEDO e M. LOBO DA COSTA em Estudos de história do processo, FIEO e Joen Editora (co-edição), São Paulo, 1996, p. 101.

${ }^{95}$ Memória que também levou o accessit, e tracta do direito de correição usado nos antigos tempos, e nos modernos, e qual seja a sua natureza, Memórias de Litteratura Portugueza, T. II, 1792, p. 208.
} 
principais coisas que se tratam em juízo sejam escritas ${ }^{96}$; a do ano de 1322 , que estabeleceu que não valia o testemunho de cristão contra judeu sem que outros judeus testemunhassem também ${ }^{97}$; a que proibiu o costume de os particulares realizarem penhora por autoridade própria, determinando que ninguém penhorasse sem mordomo, saião ou porteiro ${ }^{98}$ (funcionários subalternos da administração da justiça); a que estabeleceu que as sentenças confirmadas pelos sobrejuízes ou ouvidores da Suplicação não podiam ser revogadas, e se a parte as quisesse revogar, que pagasse quinhentos $\operatorname{soldos}^{99}$; a de 1282, que repreendeu os advogados pelas delongas que causavam nas demandas; a que mandou aos sobrejuízes que castigassem os advogados e procuradores que praticassem fraudes ${ }^{100}$; a que mandou que os documentos fossem redigidos em português, pois até então eram em latim.

De D. Afonso IV: o Regimento das Audiências da Corte ${ }^{101}$, que determinou que houvesse na corte quatro sobrejuízes, dois clérigos e dois leigos, formando dois grupos, cada qual com jurisdição territorial demarcada, composto por um clérigo e um leigo; que nas terras em que o rei andasse, seria acompanhado por dois ouvidores, um clérigo e um leigo, encarregados do julgamento dos feitos cíveis; que para os feitos criminais haveria quatro ouvidores, dois na corte, e dois que acompanhassem o monarca; e que para os feitos fiscais haveria três ouvidores, dois leigos e um clérigo. Nesse regimento que fica nítida a separação de funções entre os juízes da suplicação e os juízes da apelação civil $^{102}$. Em 1337 $7^{103}$, estabeleceram-se dois sobrejuízes letrados e detentores de reconhecido saber jurídico («entendidos», na linguagem da época) para os feitos cíveis, dois ouvidores para os feitos criminais, e mais dois ouvidores para os feitos da Coroa. As sentenças seriam dadas por dois juízes, e quando não houvesse acordo entre eles, julgariam todos os seis, prevalecendo o voto da maioria. Se houvesse empate, dariam conhecimento

\footnotetext{
${ }^{96}$ J. VERISSIMO ÁlVARES DA SILVA, Memoria sobre a forma dos juizos nos primeiros seculos da monarquia portugueza, Memorias da Litteratura Portugueza, t. VI, Lisboa, 1796, p. 56.

97 J. Veríssimo Álvares DA SILVA, Sobre a forma dos juízos nos primeiros séculos da monarquia portugueza, Memorias de Litteratura Portugueza, t. VI, p. 58.

98 J. VERÍsSIMO Álvares DA SILVA, Sobre a forma dos juízos nos primeiros séculos da monarquia portugueza, Memorias de Litteratura Portugueza, t. VI, p. 46.

${ }^{99}$ J. VERÍSSIMO ÁlVARES DA SILVA, Memoria sobre a forma dos juízos nos primeiros séculos da monarquia portugueza, Memorias de Litteratura Portugueza, t. VI, Lisboa, 1796, p. 68.

${ }^{100}$ J. VeRÍSSIMO ÁllVARES DA SILVA, Memoria sobre a forma dos juízos nos primeiros séculos da monarquia portugueza, Memorias de Litteratura Portugueza, t. VI, Lisboa, 1796, p. 81.

${ }^{101}$ De data desconhecida, esse regimento foi promulgado entre o princípio e o fim do reinado de D. Afonso IV. GAMA BARROS, embora enumere indícios em sentido contrario, inclina-se a acreditar que ele seja posterior à reforma feita por esse soberano em 1337.

${ }^{102}$ H. DA GAMA BARROS, História da administração pública em Portugal nos séculos XII a XV, t. III, $2^{\mathrm{a}}$ ed., Livraria Sá da Costa, 1946, p. 267-69.

${ }^{103}$ Para GAMA BARRos, a datação dessa reforma está incorreta no Livro das Leis e Posturas, sendo a data correta 1337.
} 
ao rei. Pode-se afirmar que a sede do tribunal era em lugar fixo, porque há previsão de que, se o rei estivesse ausente, o conhecimento do empate a ele se faria por carta selada contendo os votos de cada um dos juízes. As sessões seriam todos os sábados, ou, se houvesse impedimento, às sextas-feiras ${ }^{104}$.

Uma lei de D. Afonso IV limitou a apelação das sentenças interlocutórias a dois casos: 1) quando o juiz extinguia ou suspendia o andamento do processo, como, por exemplo, quando julgava que o réu não devia ser citado, ou se declarava incompetente («o juiz se dava por não juiz»); 2) quando a interlocutória impunha gravame irreparável pela definitividade dos efeitos, $v . g$., quando mandava por o réu a tormentos ${ }^{105}$.

D. Afonso IV, para evitar demandas, mandou que não houvesse advogados residentes na corte, nem em nenhuma parte; e que para a decisão do pleito os juízes fizessem às partes as perguntas que bem lhes parecesse ${ }^{106}$.

D. Pedro I reformou o Regimento de Audiências da Corte. Por essa reforma, o tribunal de apelação civil era o mesmo que o tribunal de agravos. Era possível suplicar ao rei contra as sentenças dos sobrejuízes, desde que o recorrente pagasse na chancelaria vinte e cinco libras em dinheiro antes de lhe conhecerem do agravo. Desse regimento se deduz que, ao contrário do que fizera seu pai, para D. Pedro I os feitos criminais e cíveis têm junto ao rei os mesmos juízes. Todavia, nos reinados subseqüentes, prevaleceu a reforma de D. Afonso IV, de modo que, nas Cortes de Lisboa de 1371, art. 18, há menção aos «nossos sobrejuízes da nossa casa do cível»; e nas Cortes de Leiria, de 1372, mencionamse os «nossos ouvidores e sobrejuízes das nossas casas», o que demonstra a existência de um tribunal para as causas cíveis, e que as causas cíveis e criminais eram julgadas por magistrados diversos ${ }^{107}$.

Há uma lei de D. Pedro I que condena à morte o juiz que se deixa corromper $^{108}$.

\footnotetext{
${ }^{104}$ H. DA GAMA BARros, História da administração pública em Portugal nos séculos XII a XV, t. III, $2^{\mathrm{a}}$ ed., Livraria Sá da Costa, 1946, p. 266-67.

105 J. VERÍSSIMO ÁlVARES DA SILVA, Memoria sobre a forma dos juízos nos primeiros séculos da monarquia portugueza, Memorias de Litteratura Portugueza, t. VI, Lisboa, 1796, p. 71.

${ }^{106}$ Memoria que também levou o accessit, e tracta do direito de correição usado nos antigos tempos, e nos modernos, e qual seja a sua natureza, Memorias de Litteratura Portugueza, t. II, 1792, p. 209. Essa lei também é mencionada por J. VerísSIMO Álvares DA SILVA em Memoria sobre a forma dos juízos nos primeiros séculos da monarquia portugueza, Memorias de Litteratura Portugueza, t. VI, Lisboa, 1796, p. 82. ${ }^{107}$ H. DA GAMA BARROS, História da administração pública em Portugal nos séculos XII a XV, t. III, $2^{\mathrm{a}}$ ed., Livraria Sá da Costa, 1946, p. 269.

${ }^{108}$ Memoria que também levou o accessit, e tracta do direito de correição usado nos antigos tempos, e nos modernos, e qual seja a sua natureza, Memorias de Litteratura Portugueza, t. II, 1792, p. 208.
} 
D. Fernando determinou estabeleceu que os contratos que passassem de certa quantia não produzissem ação se não fossem feitos por escritura pública ${ }^{109}$.

109 J. Veríssimo Álvares DA SILVA, Sobre a forma dos juízos nos primeiros séculos da monarquia portugueza, Memorias de Litteratura Portugueza, t. VI, p. 59. 


\section{2. ÓRGÃOS JURISDICIONAIS}

\section{$2.1 O P A P A$}

Chefe supremo da Igreja universal, o papa naturalmente exercia, na época em estudo -- como a exerce até hoje --, a jurisdição máxima sobre os clérigos de Portugal. Exemplo de decisão papal proferida em conflito entre eclesiásticos foi o rescrito de Gregório IX, em 18 de março de 1235, ordenando que párocos pagassem as terças pontificais a D. Martinho Rodrigues, bispo do Porto. Essas terças pontificais eram o terço do rendimento das paróquias, e pertenciam ao bispo. Como D. Martinho havia permanecido longo tempo em Roma, os párocos sustentavam que as terças que não lhe foram pagas estavam prescritas ${ }^{110}$.

Mas a jurisdição papal, naquela época, ia muito além dos assuntos eclesiásticos. O papa exercia também o supremo poder secular, acima dos reis. Sua competência era universal, e o Tribunal Pontifício, no apogeu da idade média, era o mais alto grau de apelo, ao qual eram levados recursos oriundos dos tribunais civis ${ }^{111}$.

Ao menos em dois momentos do período em exame a jurisdição papal se mostrou decisiva na história de Portugal: no litígio entre D. Afonso II e suas irmãs perante o papa Inocêncio III, e na deposição de D. Sancho II por Inocêncio IV.

D. Sancho I deixou em testamento a sua filha D. Teresa, rainha divorciada de Leão, o senhorio das vilas de Montemor e Esgueira; o de Alenquer a outra filha, D. Sancha; e os mosteiros de Arouca, Bouças e Tuyas a D. Mafalda, também sua filha. Diante da recusa de D. Afonso II a cumprir o testamento de seu pai, suas irmãs se dirigiram ao papa, solicitando a confirmação do testamento. D. Afonso II enviou a Roma como advogado um certo Silvestre, que talvez seja o que foi depois arcebispo de Braga. Depois, foram também defensores do rei o bispo de Lisboa, Soeiro, e o deão da mesma sé, mestre Vicente $^{112}$. Inocêncio III nomeou os bispos de Astorga, de Burgos e de Segóvia como delegados ad hoc para a instrução e julgamento da causa. A defesa do rei se baseava na

\footnotetext{
${ }^{110}$ A. Herculano, História de Portugal, t. 4, Livrarias Aillaud \& Bertand - Livraria Francisco Alves, Paris - Lisboa - Rio - São Paulo - Belo Horizonte, $8^{a}$ ed., p. 254.

${ }^{111}$ L. C. DE AZEVEDO, O direito de ser citado, FIEO e Resenha Universitária (co-edição), São Paulo, 1980, p. 176.

${ }^{112} \mathrm{~J}$. A de Figueiredo afirma que nesse litígio serviu também de serviu de procurador do rei em Roma o mestre Leonardo (J. A. DE FIGUEIREDO, Memoria sobre qual foi a época certa da introducção do direito de Justiniano em Portugal, Memorias da Litteratura Portugueza, t. I, Lisboa, 1792, p. 273).
} 
suposta loucura de D. Sancho I à época em que fez o testamento, e na bula de Alexandre III que garantia aos sucessores de D. Afonso Henriques a posse do reino e a dignidade de rei. Argumentava Silvestre que era proibido aos reis de Portugal alienar a mínima porção de bens públicos em prejuízo do herdeiro da coroa. Nesse ínterim, D. Mafalda doou sua herança, com reserva de usufruto, à Ordem do Hospital, que entrou no litígio. Portugal entrou em uma guerra civil por causa desse litígio, e as princesas, além da ajuda bélica de diversos nobres, obtiveram do arcebispo de Compostela e do bispo de Zamora, que tinham sido nomeados por D. Sancho I como executores de seu testamento, a excomunhão de D. Afonso II e a interdição do reino de Portugal. O rei apelou ao papa, que nomeou os abades de Spina e de Osseira como juízes, com o objetivo de fazerem o rei e suas irmãs chegarem a um acordo. Se esse acordo não fosse possível, esses abades deveriam fazer um inquérito exato sobre os fatos e enviá-lo a Roma, onde D. Afonso II e as princesas deveriam sustentar suas razões por procuradores idôneos. As censuras contra o rei foram levantadas em janeiro de 1214, mas ele foi condenado a pagar cinquienta mil morabitinos em favor das infantas. O rei se recusou a pagar essa quantia e apelou novamente a Roma, o que levou os juízes a excomungá-lo novamente. Inocêncio III tornou a anular as censuras, confiando aos templários a guarda dos castelos legados às infantas D. Teresa e D. Sancha. Os templários deveriam assegurar que essas infantas vivessem pacificamente nesses castelos, e que nenhum mal ao rei ou ao reino neles se pudesse fazer. Os juízes foram substituídos pelo bispo de Burgos e o deão de Compostela, também encarregados de fazer um inquérito sobre a justiça ou injustiça das pretensões de cada uma das partes. Quanto a D. Mafalda, o papa, logo em 1211, confirmou o testamento de D. Sancho I, limitando-o, porém, ao direito de padroado. O padroado significava para o padroeiro a maior e melhor porção das rendas de um mosteiro. Entretanto, em março de 1212, Inocêncio III publicou uma bula que, tacitamente, revogava a confirmação em favor de D. Mafalda. Esta se tornou depois rainha consorte de Castela, e não há vestígios de que continuou o processo contra seu irmão. O casamento de D. Mafalda com o rei Henrique I, que tinha pouco mais de dez anos, foi anulado por Inocêncio III antes da consumação, e D. Mafalda voltou a Portugal, passando a residir no mosteiro de Arouca, onde terminou sua vida como monja. O processo de D. Teresa e D. Sancha contra o rei só terminou após a morte deste, por um acordo celebrado entre D. Sancho II e suas tias, acordo que incluiu também D. Branca, que não entrara no 
litígio. D. Afonso II teve ainda outra irmã, D. Berengária, que foi rainha da Dinamarca, e dois irmãos, D. Pedro e D. Fernando, que preferiram viver no exterior a lutar contra ele ${ }^{113}$.

Um fato que merece ser posto em relevo é que, durante esse litígio, no final de 1213, quando ainda estavam em vigor as censuras impostas pelos abades de Osseira e de Spina, o papa cobrou ao rei de Portugal, por meio de um legado pontifício, frei Gonçalo, espanhol de nascimento, os censos em atraso. Ao conceder o título de rei a D. Afonso Henriques, a Santa Sé tornara-se suserana do reino de Portugal, que devia, em razão disso, pagar-lhe o censo, que consistia em dois marcos de ouro por ano. Todavia, os reis de Portugal tinham repugnância em reconhecer a supremacia temporal do sumo pontífice, tanto que D. Afonso Henriques nunca pagou esses dois marcos de ouro, e D. Sancho I só os pagou quando foi obrigado pelas circunstâncias. D. Afonso II, como seu pai e seu avô, não vinha pagando os censos, mas, nas circunstâncias em que foi cobrado, pagou a frei Gonçalo três mil e seiscentos morabitinos, que equivaliam a cinqüenta e seis marcos de ouro, ou seja, vinte e oito anos de censo. Ora, como D. Sancho I pagara todos os censos vencidos até 1198 ou 1199, a dívida não excedia a metade da quantia recebida por frei Gonçalo, o qual deu quitação geral até o final de 1213. Não se sabe se o rei não possuía provas do pagamento anterior, ou se não lhe convinha discutir com o legado pontifício sobre valores naquelas circunstâncias; o que se sabe é que o rei pagou mil e seiscentos morabitinos a mais, e que, semanas depois, suas censuras foram levantadas ${ }^{114}$.

A deposição de D. Sancho II foi o desfecho de uma longa desavença entre a coroa e o clero. Várias queixas já haviam sido encaminhadas a Roma pelos prelados do reino, nas quais o rei era acusado de ser inepto, de não ser capaz de administrar o reino e de reprimir as desordens que se acumulavam, e o papa chegara a advertir o rei de que, se fosse remisso em suas obrigações, acabaria a tolerância da Sé Apostólica e seriam tomadas as providências oportunas. Por ocasião do Concílio de Lião, os bispos do Porto e de Coimbra, encarregados de dar conta à Santa Sé do procedimento do rei, relataram pessoalmente a Inocêncio IV, provavelmente com exagero, que D. Sancho II, ao invés de se emendar, se mostrava mais negligente e descuidado. Além disso, o rei, que era naturalmente pródigo, foi acusado por seus inimigos de estar mentecapto. Esses bispos, mais o arcebispo de Braga, levaram ao papa cartas de vários nobres, eclesiásticos e de alguns concelhos, descrevendo a situação do reino. A defesa do rei no concílio foi feita pelo bispo de Lisboa, Aires. O concílio de Lião teve três sessões, na última das quais foi

113 A. HerCulano, História de Portugal, v. 4, p. 7-68.

${ }^{114}$ A. HerCulano, História de Portugal, v. 4, p. 57-58. 
deposto o imperador Frederico. Na semana seguinte, por uma bula, Inocêncio IV depôs D. Sancho II do trono e designou o conde de Bolonha, irmão do rei e seu sucessor, caso D. Sancho II não tivesse filhos legítimos, para restaurar o reino. Com essa bula, o arcebispo de Braga e o bispo de Coimbra se dirigiram a Paris, e lá tomaram o juramento de D. Afonso, que se dirigiu a Portugal e assumiu o governo, não sem guerra civil. D. Sancho II morreu em Toledo, em 1248, e a partir daí D. Afonso III foi coroado rei ${ }^{115}$.

O fundamento para a deposição de D. Sancho II foi a declaração de que ele, como os Merovíngios na França do século VIII e Eduardo II na Inglaterra do século XIV, foi considerado rex inutilis. Essa declaração, «shadow king» em inglês, tinha, na idade média, o condão de legitimar uma usurpação ${ }^{116}$.

\section{$2.2 O R E I$}

O rei cristão medieval tem três funções: ele é o «justiceiro», o «pacificador», e o «fiador da prosperidade» de seu povo ${ }^{117}$. Assim, a primeira das funções régias coloca-o no ápice da organização judiciária de seu reino.

S. Luis, o nono desse nome, rei da França, costumava sentar-se na terra, à sombra de um carvalho, sobre um tapete, para ouvir causas judiciárias, sobretudo as dos pobres e dos órfãos, e lhes fazer justiça. Até mesmo fora de seus domínios, quando estava na Palestina, Luis IX fez algumas condenações ou julgamentos, e num deles mandou expor no pelourinho um ourives blasfemador. Em Paris, mandou queimar os lábios e o nariz de um burguês, também acusado de blasfêmia. Sua justiça era rigorosa também com os nobres, como o provou o julgamento de Enguerran, senhor de Coucy ${ }^{118}$.

Ora, em Portugal, a concepção sobre o papel do rei não era muito diferente. Segundo os ensinamentos de S. Isidoro de Sevilha que passaram para o Código Visigótico, são deveres do rei: a chefia militar, a realização da justiça, a proteção da Igreja e o desenvolvimento do território. Especificamente quanto à realização da justiça, o Código Visigótico estabelecia: rex eris si recte faceris $^{119}$.

\footnotetext{
115 A. Herculano, História de Portugal, v. 5, p. 7-81

${ }^{116}$ J. Le Goff e J. C. SCHMitT, Dicionário Temático do Ocidente Medieval, v. II, EDUSC, Bauru, 2006, p. 407.

${ }^{117}$ J. LE GofF, São Luis, Record, Rio - São Paulo, $3^{\mathrm{a}}$ ed., 2002, p. 568-576.

118 J. Le GofF, São Luis, Record, Rio - São Paulo, $3^{\mathrm{a}}$ ed., 2002, p. 570-71.

${ }^{119}$ M. Caetano, História do Direito Português, Verbo, Lisboa - São Paulo, $4^{\mathrm{a}}$ ed., 2000, p. 206-07.
} 
C. SANChEZ-Albornoz descreve com riqueza de pormenores um julgamento realizado em Leão, no século X. Após uma assembléia de bispos e próceres do reino, o conde Osório Gutierrez, ao se despedir do rei Ramiro II, lhe pede autorização para entregar a D. Gunterode, sua parenta, a Casa de Santa Columba, na Galícia, que está na posse de um tal Odoíno, apesar de sua protegida ter as escrituras que comprovam seu direito. Além disso, havia o testemunho do bispo Hermenegildo de Santiago. O monarca, ao invés de atender prontamente tal petição, manda chamar o bispo arrolado, que já estava a caminho de volta para sua diocese. Trazido à presença do rei, o bispo afirma que o legítimo possuidor da Casa de Santa Columba é Odoíno. O monarca então decide mandar citar o conde Osório Gutierrez e convocar todos os bispos e magnates presentes na corte para um julgamento, entre a hora nona e a noturna. Logo saiões percorrem toda a cidade e o acampamento anexo, e servos do palácio começam a transportar vigas e madeiras para levantar o tablado em que será colocado o sólio do monarca, depois o próprio sólio, cadeiras, bancos e tamboretes para os infantes e grandes da corte. $\mathrm{O}$ rei veste as roupas de cerimônia, o diadema de pontas, o cetro. Reúnem-se ao rei seus filhos os infantes D. Sancho e D. Ordonho, vestidos com seda e brocado e, acompanhados de um séquito, todos saem do palácio e se dirigem até as termas transformadas em Igreja. O monarca é precedido pelos arqueiros e os lanceiros de sua guarda seguem os infantes, o bispo da cidade, o alferes, o mordomo, o notário, os condes do palácio e os soldados da milícia real. No átrio os aguardam bispos, condes e magnatas, com os clérigos, infanções e escudeiros de seus séquitos. Todos trazem consigo suas espadas e estão vestidos com apuro. Com a chegada da corte, o rei se assenta no sólio e impõe silêncio à assembléia com um gesto. Dirige-se aos dois litigantes e inicia o julgamento com as palavras: veritatem loquimini michi de hanc rem pro quo uos in concilio pulsantur. Levanta-se de seu lugar o conde Osório e começa suas alegações em favor de D. Gunterode: Misericordiam peto: Domine, vestras queso prebete aures, nostras audite querimonias. E explica pormenorizadamente os direitos de D. Gunterode que a fazem proprietária de Santa Columba. Responde-lhe o bispo Hermenegildo: Tu, domine, mi rex audiat clementia vestra, e relata o assunto, afirmando que as escrituras de D. Gunterode haviam sido invalidadas pelo rei predecessor de Ramiro. Houve réplica e tréplica. Após, o rei consulta seus filhos e alguns bispos eleitos juízes para atuar no caso - atuação que consistia em indicar as provas cabíveis, missão fundamental, e no mais das vezes única, que competia aos juízes no procedimento germânico de uso quase geral no século X. Depois, em pé, o rei ordena que Hermenegildo 
e cinco dos seus prestem juramento no átrio da igreja. $\mathrm{O}$ bispo se volta para os seus e elege os conjuradores entre os seus infanções e clérigos, mas, antes que termine, o conde Osório desiste do processo. No século $\mathrm{X}$, o juramento era o mais freqüente meio de prova, sobrepujando a documental e testemunhal, e nas épocas mais antigas, quando admitidas as ordálias, a chamada ordália da água quente, em uso desde a época visigoda. A desistência do autor punha fim ao processo e era lavrada uma escritura do acordo chamada agnitio ${ }^{120}$.

Na monarquia portuguesa, antes de o primo de São Luis ${ }^{121}$, D. Afonso III, haver promulgado uma lei sobre apelação ${ }^{122}$, os reis portugueses freqüentemente exerciam a jurisdição em primeiro grau. Exemplo disso é D. Afonso Henriques, que julgou, na presença de vários bispos, o conflito do abade de Soalhães e Gonçalo Afonso com Pedro Paes $^{123}$.

Às vezes a jurisdição real podia ser delegada, como quando, no reinado de D. Afonso III, a Prioresa de Santa Ana de Coimbra, D. Tereza Dias, se queixou a ele de agravos que the fazia D. Gomes Lourenço, o rei remeteu a decisão ao Concelho de Coimbra, que mandou a D. Gomes que cessasse tal conduta ${ }^{124}$.

Mas, de todos os reis do período em exame, o que mais se identificou com o ideal de rei justiceiro foi D. Pedro I:

Quando em 1357 sobe ao trono um príncipe epilético, D. Pedro I (que todavia já tinha as rédeas do governo desde 1355 pela doença de seu pai), a idéia de que a justiça é a primeira virtude dos reis transformase em paranóia. O cognome de Justiceiro, com que passou à história, irmana-se ao de Cruel. Fernão Lopes, na Crônica... que escreveu do seu reinado, alterna os louvores ao zelo do rei em não deixar malefício sem castigo, punindo por igual os humildes e poderosos, com a narração dos procedimentos reveladores do prazer sádico de ver sofrer, quando o próprio monarca se transformava em verdugo, inquirindo ele próprio os suspeitos, mandando-os meter a tormento, açoutando por sua mão os malfeitores e inventando sanções crudelíssimas quando o crime mais lhe despertava os instintos perversos ${ }^{125}$.

\footnotetext{
${ }^{120}$ C. SANCHEZ-AlbornOZ, Una ciudad de España cristiana hace mil anos, Rialp, Madrid, 1977, p. 57-85.

${ }^{121}$ A mãe de D. Sancho II e de D. Afonso III, D. Urraca de Castela, era irmão da mãe de S. Luis, a rainhamãe da França, Branca de Castela.

122 J. VERÍSSIMO ÁLVARES DA SILVA, Memoria sobre a forma dos juízos nos primeiros séculos da monarquia portugueza, Memorias de Litteratura Portugueza, t. VI, Lisboa, 1796, p. 67. Essa lei, que teria sido passada nas Cortes de Leiria, em 1254, ou nas Cortes de Coimbra, em 1261, é reproduzida por L. C. DE AZEVEDO e M. LOBO DA COSTA em Estudos de história do processo, FIEO e Joen Editora (co-edição), São Paulo, 1996, p. 80 .

${ }^{123}$ Memoria que também levou o accessit, e tracta do direito de correição usado nos antigos tempos, e nos modernos, e qual seja a sua natureza, Memorias de Litteratura Portugueza, t. II, 1792, p. 200.

${ }^{124}$ Memoria que também levou o accessit, e tracta do direito de correição usado nos antigos tempos, e nos modernos, e qual seja a sua natureza, Memorias de Litteratura Portugueza, t. II, 1792, p. 200-01.

${ }^{125}$ M. CAetano, História do Direito Português, Verbo, Lisboa - São Paulo, $4^{\mathrm{a}}$ ed., 2000, p. 300.
} 


\subsection{O CONSELHO DO REI}

A monarquia portuguesa, ao desprender-se da castelhana, surgiu dotada de todos os organismos desta. Somente o transcurso dos tempos, a idiossincrasia de cada um desses povos e a sua vida autônoma puderam criar as particularidades que os diferenciaram entre si. Logo, a cúria régia portuguesa, tanto quanto a castelhana, derivou de organismos visigodos formados a partir de elementos romanos, germânicos e eclesiásticos ${ }^{126}$.

Pois bem. Os reis visigóticos eram auxiliados no governo tanto pelos concílios quanto pela aula régia, ou ofício palatino. Os concílios, à época, não se limitavam aos assuntos eclesiásticos, mas também intervinham em questões alheias ao governo da Igreja, e, em união com o ofício palatino, limitavam o poder absoluto da realeza. Quando da queda da monarquia visigótica e constituição do Estado asturiano, os concílios e a aula régia acabaram por se fundir na cúria régia, que, tanto em sessões ordinárias como extraordinárias, eram integrada por membros da família real, bispos, abades e dignitários dos mais elevados graus da nobreza, que tratavam de assuntos religiosos, militares, políticos e judiciais ${ }^{127}$.

Inicialmente esse organismo recebeu os nomes de palatium, palatinum collegium, senatus togae palatii, e o nome genérico de concilium; a partir do século XI impõe-se o uso da palavra cúria.

Há similitude entre alguns dos vocábulos acima apontados e aqueles usados na França para designar a corte carolíngia, chamada por seus contemporâneos de aula e palatium. E os que cercavam o rei eram chamados de palatini e formavam o palatium. Assim, o palatium era, ao mesmo tempo, um lugar e um grupo de pessoas ${ }^{128}$. E com o desaparecimento dos carolíngios, no século $X$, sem que a palavra palatium logo desaparecesse, surge e começa a se impor pouco a pouco a palavra cúria ${ }^{129}$.

Não havia problema da administração, do governo ou da justiça em que esse organismo não interviesse ${ }^{130}$.

\footnotetext{
${ }^{126}$ C. SANCHEZ-ALBORNOZ, Investigaciones y documentos sobre las instituciones hispanas, Editorial Jurídica de Chile, Santiago, 1970, p. 381.

${ }^{127}$ C. SANCHEZ-ALBORNOZ, Investigaciones y documentos sobre las instituciones hispanas, Editorial Jurídica de Chile, Santiago, 1970, p. 384.

${ }^{128}$ J. Le Goff e J. C. SCHMitT, Dicionário Temático do Ocidente Medieval, v. I, EDUSC, Bauru, 2006, p. 269.

${ }^{129}$ J. Le Goff e J. C. SChMiTt, Dicionário Temático do Ocidente Medieval, v. I, EDUSC, Bauru, 2006, p. 272.

${ }^{130}$ C. SANCHEZ-ALBORNOZ, Investigaciones y documentos sobre las instituciones hispanas, Editorial Jurídica de Chile, Santiago, 1970, p. 385
} 
Desde a independência de Portugal, os concílios nunca se confundiram com a cúria. Nos concílios provinciais de Braga e Coimbra de 1148 e 1163, e no concílio nacional de Braga de 1262, em nada intervieram o rei e os magnatas; o que não quer dizer que a cúria não interviesse em alguns assuntos eclesiásticos, e no judicial, quando a isenção do clero não era ainda um direito absoluto ${ }^{131}$.

As cúrias poderiam ser ordinárias ou extraordinárias. Cúrias ordinárias eram reuniões a que acorriam, convocados sem qualquer formalidade, quiçá verbalmente ${ }^{132}$, os membros da família real que habitavam com o rei (rainha, infantes, e até irmãs do rei), os mais importantes oficiais do palácio (mordomo, chanceler, alferes), quiçá alguns de graus inferiores, os dignitários laicos que acidentalmente se encontravam no séquito real, na qualidade de amigos e conselheiros do soberano, seja porque o príncipe se encontrava nas terras deles, seja porque eles haviam acorrido à corte, e os bispos e abades que por causas análogas se encontravam acidentalmente junto ao rei. Já a cúria plena, que se realizava em reuniões extraordinárias, que requeriam convocação especial, feita pelos saiões ou porteiros reais, que fixava o prazo para a realização da reunião e o lugar em que devia realizar-se. A extensão do chamado era variável. Podiam ser plenas, quando eram convocados a todos os nobres e altos dignitários eclesiásticos do reino; ou regionais, quando se citavam os de uma ou algumas regiões determinadas; e, raríssimas vezes, apenas membros da nobreza ${ }^{133}$.

Em Portugal, a cúria régia ordinária deu origem ao Conselho do Rei, e a cúria régia extraordinária, às Cortes ${ }^{134}$.

Os mais antigos documentos da monarquia portuguesa, em latim, se referem à curia, havendo um, o foral de Idanha Velha, de 1229, que fala in concilio generali; a carta régia de 14 de maio de 1412 fala em «ajuntamentos»; e uma carta de Afonso IV, datada de 20 de abril de 1355, diz: Et cum ego celebrare seu facerem Cortes vel Curias seu Parlamenta $^{135}$.

\footnotetext{
${ }^{131}$ C. SANCHEZ-ALBORNOZ, Investigaciones y documentos sobre las instituciones hispanas, Editorial Jurídica de Chile, Santiago, 1970, p. 410.

${ }^{132}$ C. SANCHEZ-ALBORNOZ, Investigaciones y documentos sobre las instituciones hispanas, Editorial Jurídica de Chile, Santiago, 1970, p. 394.

${ }^{133}$ C. SANCHEZ-AlBORNOZ, Investigaciones y documentos sobre las instituciones hispanas, Editorial Jurídica de Chile, Santiago, 1970, p. 385.

${ }^{134}$ P. Ferreira Da CUNHA, J. Aguiar e Silva e A. Lemos SoARes, História do Direito, Almedina, Coimbra, 2005, p. 411.

${ }^{135}$ H. DA Gama Barros, História da Administração Pública em Portugal nos Séculos XII a XV, t. 1, Lisboa, Imprensa Nacional, 1885, p. 539.
} 
Há exemplos de que o conselho do rei tinha função jurisdicional quando o soberano lhe delegasse o julgamento de um litígio que lhe fora submetido: em 1266, João Peres de Farina, Tenente de Mortua, demandou contra os particulares Domingos Fernandes, Miguel Pelaes e Domingos Partenes, que não queriam pagar-lhe quantias que, como governador, lhe eram devidas, e a conselho decidiu a seu favor, de modo que os três tiveram de pagar-lhas desse dia em diante; em 1272, o Mestre da Ordem Militar de S. Tiago se queixou ao rei de que os homens de suas terras eram coagidos ao serviço de «adeca». Afonso III levou o assunto ao conselho, que, depois de ouvir as partes, decretou que somente seis vassalos da Ordem fossem escusados de tal serviço ${ }^{136}$.

O conselho do rei foi, desde os primeiros tempos de Portugal, dotado de jurisconsultos. Antes mesmo da proclamação da independência, D. Afonso Henriques já tinha como conselheiro o célebre D. João Peculiar, francês ou português de nascimento, formado em direito civil e canônico, que primeiro foi mestre-escola da sé de Coimbra, depois bispo do Porto, e depois, em 1138, Arcebispo de Braga. Foi chanceler de D. Afonso Henriques o mestre Alberto, estrangeiro ${ }^{137}$.

Aos que tinham formação jurídica, nessa época, em que ainda não haviam sido instituídos os graus acadêmicos, era dado ou o título de mestre, ou eram chamados de fulanos das leis. Daí supõe J. A. DE FIGUEIREDo que a palavra mestre se aplicasse àqueles que, ainda que particularmente, ensinavam o direito ${ }^{138}$.

Quando sucedeu a seu pai, em 1185, D. Sancho I mandou vir de Milão o jurisconsulto Leonardo, e nomeou também para o seu conselho o mestre Vicente, deão de Lisboa $^{139}$.

Depois de ser coroado, D. Afonso II se serviu, em seu conselho, dos dois jurisconsultos nomeados por seu pai, e ainda nomeou também como conselheiros o magister dominicus, arcediago de Santarém, o magister petrus, deão de Lisboa, o magister Fernandus, e o magister Pelagius Cantor Portugallensis ou Portuensis, também conhecido como mestre Payo, chantre do Porto ${ }^{140}$.

\footnotetext{
${ }^{136}$ C. SANCHEZ-ALBORNOZ, Investigaciones y documentos sobre las instituciones hispanas, Editorial Jurídica de Chile, Santiago, 1970, p. 408-09.

${ }^{137}$ J. A. DE FIGUEIREDO, Memoria sobre qual foi a época certa da introducção do direito de Justiniano em Portugal, Memorias da Litteratura Portugueza, t. I, Lisboa, 1792, p. 272.

${ }^{138} \mathrm{~J}$. A. DE FigueIREDO, Memoria sobre qual foi a época certa da introducção do direito de Justiniano em Portugal, Memorias da Litteratura Portugueza, t. I, Lisboa, 1792, p. 272-73.

${ }^{139} \mathrm{~J}$. A. DE FIGUEIREDO, Memoria sobre qual foi a época certa da introducção do direito de Justiniano em Portugal, Memorias da Litteratura Portugueza, t. I, Lisboa, 1792, p. 273.

${ }^{140} \mathrm{~J}$. A. DE FigueIREDO, Memoria sobre qual foi a época certa da introducção do direito de Justiniano em Portugal, Memorias da Litteratura Portugueza, t. I, Lisboa, 1792, p. 274.
} 
D. Afonso IV nomeou para o seu conselho o mestre João das Leis, o mestre Vicente das Leis, mestre Pedro, mestre Gonçalo das Leis. E D. Pedro teve por conselheiros, entre outros, o mestre Vasco das Leis, João Esteves e mestre Afonso ${ }^{141}$.

Quando D. João I foi escolhido regedor e defensor do reino, em 1383, nomeou sete conselheiros, dos quais eram legistas o Doutor João das Regras, o licenciado João Gil, Lourenço Esteves, João Afonso de Azambuja, este último, futuro arcebispo de Lisboa e cardeal. João Gil e Lourenço Esteves foram também nomeados desembargadores do paço e procuradores da fazenda ${ }^{142}$.

Nas Cortes de 1385, D. João I escolheu, dentre quatorze que lhe foram indicados como conselheiros, um prelado, dois fidalgos, três letrados e quatro cidadãos. Desses quatro, um era de Lisboa, outro do Porto, outro de Coimbra, outro de Évora ${ }^{143}$.

Em 1411, o mesmo D. João I, ouvidos os de seu conselho, estabeleceu que, para diminuir as despesas da coroa, não o acompanhassem mais que quatro conselheiros, recebendo estipêndio; e que, se mais algum fosse chamado à corte, só o receberia se tivesse de se demorar por mais de quinze dias ${ }^{144}$.

Durante o reinado de D. João I se adotou o costume de falarem primeiro os conselheiros menos graduados. Até então, era o contrário ${ }^{145}$.

Dom Duarte, durante todo o seu reinado, determinou que andassem sempre na corte um dos infantes, um conde e um bispo, que seriam revezados a cada trimestre ${ }^{146}$.

Nas Cortes de Leiria de 1372, art. 10, os povos reclamaram a D. Fernando de que ele não ouvia seus conselheiros. E justamente a esses conselheiros são responsabilizados, quando da aclamação de D. João I, nas Cortes de Coimbra de 1385, art. $7^{\circ}$, de terem mal aconselhado D. Fernando, que não convocou Cortes para deliberar sobre assuntos graves como o seu casamento e a guerra que declarara a Castela. Segundo essas queixas, esses conselheiros, além de terem impelido o rei à guerra, não souberam fazê-lo achar meios de a sustentar senão empobrecendo o povo (art. 10), e ainda foram ímprobos,

\footnotetext{
${ }^{141}$ J. A. DE FigueIREDo, Memoria sobre qual foi a época certa da introducção do direito de Justiniano em Portugal, Memorias da Litteratura Portugueza, t. I, Lisboa, 1792, p. 286-87.

${ }^{142}$ H. DA GAMA BARROS, História da administração pública em Portugal nos séculos XII a XV, t. III, $2^{\mathrm{a}}$ ed., Livraria Sá da Costa, 1946, p. 256.

${ }^{143}$ H. DA GAMA BARROS, História da administração pública em Portugal nos séculos XII a XV, t. III, $2^{\mathrm{a}}$ ed., Livraria Sá da Costa, 1946, p. 257.

${ }^{144}$ H. DA GAMA BARROS, História da administração pública em Portugal nos séculos XII a XV, t. III, $2^{\mathrm{a}}$ ed., Livraria Sá da Costa, 1946, p. 258.

${ }^{145}$ H. DA GAMA BARROS, História da administração pública em Portugal nos séculos XII a XV, t. III, $2^{\mathrm{a}}$ ed., Livraria Sá da Costa, 1946, p. 258.

${ }^{146}$ H. DA Gama BARROS, História da administração pública em Portugal nos séculos XII a XV, t. III, $2^{\mathrm{a}}$ ed., Livraria Sá da Costa, 1946, p. 258.
} 
tendo enriquecido à custa do erário (art. 15). Pediram as Cortes a D. João I que excluísse esses homens dos cargos públicos e o rei declarou que atenderia esse pedido ${ }^{147}$.

\subsection{AS CORTES}

Conforme já exposto no subtítulo precedente, as Cortes tiveram origem na cúria extraordinária do direito visigótico.

Entre os primeiros momentos da reconquista e os fins do século XI ou início do século XII houve uma tendência de diminuição do número e influência dos membros eclesiásticos e um aumento da participação da nobreza, com a progressiva incorporação de nobres de graus inferiores ${ }^{148}$.

É de se considerar uma diferença essencial quanto à participação de eclesiásticos e nobres, por um lado, e dos conselhos, por outro, nas Cortes. Para a nobreza e o alto clero, a presença nas Cortes era um direito pessoal, permanente e absoluto, decorrente, no primeiro caso, do nascimento, e no segundo, da posição ocupada na hierarquia da Igreja; já quanto aos representantes dos Conselhos, seus poderes eram variáveis, pois exercidos na medida em que delegados por aqueles que os elegeram ${ }^{149}$.

O mais antigo documento sobre a participação dos concelhos nas Cortes data de 1254, no Livro 1 da Chancelaria de D. Afonso III, onde se lê que o rei de Portugal e conde de Bolonha celebrou cúria cum bonis hominibus de conciliis de suo regni, mas é admissível que os concelhos tenham participado de Cortes antes dessa data ${ }^{150}$.

É de se observar que a expressão «três estados», segundo GAMA BARROS, é relativamente moderna, sendo o documento mais antigo em que ela aparece a Carta Régia de 20 de junho de 1455; depois nas cortes de Coimbra de 1472 e nas Cortes de Évora de 1481-82.

A Universidade de Lisboa participou de algumas Cortes, tendo os seus reitores apresentado Capítulos nas de $1439^{151}$.

\footnotetext{
${ }^{147}$ H. DA GAMA BARRos, História da administração pública em Portugal nos séculos XII a XV, t. III, 2ª ed., Livraria Sá da Costa, 1946, p. 255-56.

${ }^{148}$ C. SANCHEZ-ALBORNOZ, Investigaciones y documentos sobre las instituciones hispanas, Editorial Jurídica de Chile, Santiago, 1970, p. 385.

${ }^{149}$ H. DA Gama BARros, História da Administração Pública em Portugal nos Séculos XII a XV, t. 1, Lisboa, Imprensa Nacional, 1885, p. 575.

${ }^{150}$ P. Ferreira da Cunha, J. Aguiar e Silva e A. Lemos SoAres, História do Direito, Almedina, Coimbra, 2005 , p. 412.

${ }^{151}$ M. CAETANO, História do direito português, Verbo, Lisboa/São Paulo, $4^{\mathrm{a}}$ ed. 2000, p. 471.
} 
A representação dos concelhos em Cortes era restrita aos peões e cavaleiros, excluídas as classes ínfimas ${ }^{152}$.

Não havia tempo certo para serem celebradas, exceto durante a menoridade de $\mathrm{D}$. Afonso $\mathrm{V}$, quando se determinou que se juntassem todos os anos, e durante o reinado de D. João III, que determinou fossem convocadas a cada dez anos. Os povos ora requeriam que se juntassem todos os anos, como nas Cortes de Coimbra da era ${ }^{153}$ de 1423 , ora requeriam que se juntassem a cada três anos, como nas Cortes de Lisboa da era 1409. Em a era de 1410 se celebraram duas Cortes, e em a era de 1425, três. Em suma, eram convocadas sempre que havia necessidade e não havia impedimento ${ }^{154}$.

Quanto à forma da convocação, eram convocadas pelo rei ou por quem, em seu nome, governava o reino, por meio de cartas que declaravam o lugar e o tempo da celebração, o número de procuradores que deveriam ser enviados por cada concelho, os poderes que deviam levar e, às vezes, o motivo da convocação ${ }^{155}$.

Eram convocados a nobreza, os prelados e os concelhos de vinte e uma cidades e setenta e uma vilas notáveis que, por foral ou privilégio, tinham assento em Cortes e eram representadas por procuradores, repartidos em dezoito bancos.

As Cortes podiam ser gerais ou especiais. Estas, especialmente durante a menoridade de D. Afonso V, se celebravam com número menor de assistentes, com os procuradores de apenas uma ou duas províncias do reino, ou com as cidades e vilas do primeiro banco ${ }^{156}$.

Em regra, cada concelho mandava dois procuradores, mas há exemplo de dois procuradores e um tabelião, e de apenas um procurador. Podiam ser eleitos procuradores os oficiais da Justiça e Fazenda, e até mesmo desembargadores. As despesas com o deslocamento eram suportadas pelos próprios procuradores, facultando-se nas cartas de convocação o lançamento de fintas (espécie de tributo), se suas rendas não bastassem. Quando ia um único procurador para toda uma província, todos os concelhos que a

\footnotetext{
${ }^{152}$ H. DA GAMA BARROS, História da administração pública em Portugal nos séculos XII a XV, t. III, $2^{\mathrm{a}}$ ed., Livraria Sá da Costa, 1946, p. 46. Essas classes, genericamente compreendidas sob a designação de malados, incluíam, entre outros, os solarengos e os mancebos. Mancebo era o simples jornaleiro ou criado; solarengo era aquele que, cultivando prédio alheio, tinha seu quinhão no produto da cultura (ob. cit., p. 13-14).

${ }^{153}$ Sempre que os documentos se referem a «era», a contagem é a partir do nascimento de César; se a «ano», do nascimento de Cristo.

${ }^{154}$ J. P. RIBEIRO, Sobre as fontes do código philippino, Memorias de Litteratura Portugueza, t. II, Lisboa, 1792, p. 48-49.

155 J. P. RIBEIRO, Sobre as fontes do código philippino, Memorias de Litteratura Portugueza, t. II, Lisboa, 1792, p. 49.

156 J. P. RIBEIRO, Sobre as fontes do código philippino, Memorias de Litteratura Portugueza, t. II, Lisboa, 1792, p. 49.
} 
compunham concorriam para as suas despesas. Há casos em que os príncipes concorreram para essas despesas. ${ }^{157}$.

As Cortes podiam ser convocadas pelos mais diversos motivos: expedições bélicas, celebrações de paz, casamentos, meios de concorrerem os povos com mais suavidade para as despesas do Estado, administração da justiça etc. ${ }^{158}$.

J. PEDRo Ribeiro, ao discorrer sobre a autoridade das Cortes, afirma que todas as deliberações em Cortes tinham força de lei, e contra elas não valiam Cartas ou Alvarás, salvo Cartas de graça expedidas pelos de Seu Paço, com expressa derrogação das Cortes $^{159}$. É exato que esse autor empregue a expressão «em Cortes», e não «deliberações das Cortes», pois, inicialmente, o papel das Cortes era o de apresentar casos merecedores de solução, sugerindo providências que o rei podia adotar ou não. Sua única função deliberativa era decidir sobre a cunhagem e quebra de moeda, e sobre tributos extraordinários que interessassem a toda a nação ${ }^{160}$. Nas Cortes de Coimbra de 1385 é que essas atribuições se ampliaram, tendo havido deliberação sobre a vacância do trono e a escolha do novo rei ${ }^{161}$.

Outras funções importantes das Cortes eram a de prestar menagem ao novo rei, depois de aclamado, o qual, nessa ocasião, ratificava o juramento de respeitar os foros e costumes do reino, das classes e localidades; e a de reconhecer e prometer obediência ao herdeiro da coroa ${ }^{162}$.

As Cortes conservaram sempre alguma força moral. Se não serviram de obstáculo ao crescimento do poder real, por vezes o moderaram, e numa das crises mais graves por que passou Portugal durante a idade média, a de 1385, foi nelas que se procurou a salvação da pátria ${ }^{163}$.

Os concelhos conservavam, depois, instrumentos das decisões das Cortes, em forma de carta, ou alvará, ou provisão, ou certidão, e que eram assinados pelo próprio rei, ou por quem em seu nome tinha o governo do reino, pelo escrivão da puridade (o que

\footnotetext{
157 J. P. RIBEIRO, Sobre as fontes do código philippino, Memorias de Litteratura Portugueza, t. II, Lisboa, 1792, p. 50.

${ }_{158}$ J. P. RIBEIRO, Sobre as fontes do código philippino, Memorias de Litteratura Portugueza, t. II, Lisboa, 1792, p. 52.

${ }_{159}$ J. P. RIBEIRO, Sobre as fontes do código philippino, Memorias de Litteratura Portugueza, t. II, Lisboa, 1792, p. 52-53.

${ }^{160}$ M. CAETANO, História do direito português, Verbo, Lisboa/São Paulo, $4^{\mathrm{a}}$ ed. 2000, p. 316.

${ }^{161}$ M. CAETANO, História do direito português, Verbo, Lisboa/São Paulo, $4^{a}$ ed. 2000, p. 471-472.

${ }^{162}$ M. CAETANO, História do direito português, Verbo, Lisboa/São Paulo, $4^{\mathrm{a}}$ ed. 2000, p. 475.

${ }^{163}$ H. DA GAMA BARROS, História da administração pública em Portugal nos séculos XII a XV, t. I, Lisboa, Imprensa Nacional, 1885, p. 577.
} 
conservava o selo particular do rei), secretários, ministros do paço, conselheiros ou, desde D. Duarte, principalmente, pelo chanceler-mor ou quem fazia as suas vezes ${ }^{164}$.

\subsection{JURISDIÇÕES MILITARES: ALFERES-MOR, CONDESTÁVEL E MARECHAL DA HOSTE}

Em tempo de guerra, o primeiro cargo da milícia, o mais importante, era o de alferes-mor, signifer. Se o soberano estivesse no comando da batalha, o alferes-mor permanecia ao seu lado com o pendão real. Se o soberano estivesse ausente, o alferes-mor o representava como chefe supremo das forças militares ${ }^{165}$.

Durante toda a época objeto deste estudo, o alferes-mor passou a exercer também funções públicas. Salvo a instituição do cargo de condestável, a quem passou o mais importante em batalha, os demais encargos do alferes-mor continuaram, nas Ordenações Afonsinas (Liv. I, tít. 56) a serem os mesmos que nas Partidas (Partida II, tít. 9, lei 16), inclusive o de levar a bandeira do rei quando o soberano ia na hoste.

Na primavera de 1226, D. Sancho II marchou sobre Elvas, sendo as tropas capitaneadas pelo alferes-mor Martim Annes e pelo arcebispo de Braga ${ }^{166}$.

O condestável, após a criação de seu cargo, substituiu o alferes-mor na função mais eminente no exército, com poder jurisdicional. Para isso, era acompanhado de um ouvidor letrado, com seu meirinho, e tinha à sua disposição cadeia, carcereiro e executores da justiça (Ord. Af., I, tít. 52).

Recebia proventos especiais: penas pecuniárias impostas aos delinqüentes, uma quota certa dos mercadores que vendiam ou compravam na hoste, e dos servidores deles, uma prestação semanal das meretrizes que acompanhavam o exército, e tinha o seu quinhão nos despojos (Ord. Af., I, tít. 52, §§ 18 e 20).

O marechal da hoste, inferior ao condestável, além de suas incumbências militares, conhecia, por seu ouvidor, de todos os feitos cíveis e criminais, dos quais cabia apelação, em determinados casos, para o condestável. Tinha sob as suas ordens um meirinho, carcereiro e algozes (Ord. Af., I, tít. 53).

\footnotetext{
${ }^{164}$ J. P. RIBEIRO, Sobre as fontes do código philippino, Memorias de Litteratura Portugueza, t. II, Lisboa, 1792 , p. 53.

${ }^{165}$ A. Herculano, História de Portugal, t. 4, Livrarias Aillaud \& Bertand - Livraria Francisco Alves, Paris - Lisboa - Rio - São Paulo - Belo Horizonte, $8^{\mathrm{a}}$ ed., p. 227.

${ }^{166}$ A. Herculano, História de Portugal, t. 4, Livrarias Aillaud \& Bertand - Livraria Francisco Alves, Paris

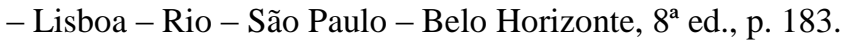


Recebia, também, parte dos despojos, as carceragens dos retidos na prisão de seu ouvidor, uma quantia certa dos que vendiam em loja ou tenda, dos mercadores e homens de mesteres (exercentes de ofícios, artes manuais ou profissões), e uma soma fixa, doze reais brancos por semana, das rameiras.

Quanto à milícia naval, aos cargos de condestável e marechal da hoste equivaliam os de almirante e capitão-mor do mar (Ord. Af., títulos 54 e 55).

\subsection{AS JURISDIÇÕES PALATINAS: MORDOMO-MOR, CHANCELER E ESCRIVÃO DA PURIDADE}

O chefe superior da administração do palácio era o maiordomus curiae, mordomo da corte ou mordomo-mor ${ }^{167}$. Seus poderes não estavam precisamente estabelecidos, mas ele exercia todos os que ao monarca aprouvesse lhe delegar.

Era designado nos documentos também por dapifer, curiae dapifer, maiordomus, maiordomus palatii, dispensator domus regiae, princeps curiae e comes palatii. Havia também o mordomo-menor, que sempre exercia funções de serventia, ao passo que o mordomo-mor, muitas vezes, tinha apenas um título honorífico ${ }^{168}$.

Era proibido de entrar nas «honras», isto é, terras, casas ou solares de propriedade dos nobres ou sob sua jurisdição, quer havidas por posse antiga, quer oferecidas por vizinhos ${ }^{169}$.

No reinado de D. Sancho I, o mordomo-mor era o conde D. Mendo, que ao morrer foi substituído por seu filho, D. Gonçalo Mendes de Sousa, chefe da mais poderosa família do país na época ${ }^{170}$.

Por ocasião da morte de D. Sancho I e início do reinado de D. Afonso II, esse mordomo-mor, Gonçalo Mendes de Sousa, foi substituído pelo antigo alferes-mor de D. Sancho I, Martim Fernandes, ao qual logo sucedeu Pedro Annes, ou Pedro Johannnes $^{171}$.

\footnotetext{
${ }^{167}$ H. DA GAMA BARRos, História da administração pública em Portugal nos séculos XII a XV, t. III, $2^{\mathrm{a}}$ ed., Livraria Sá da Costa, 1946, p. 214.

${ }^{168}$ FR. J. DE SANTA ROSA DE VITERBo, Elucidario das palavras, termos, e frases que em Portugal antiguamente se usarão, e que hoje regularmente se ignorão, t. II, Typographia Regia Silviana, Lisboa, 1799, p. 152.

169 J. P. RIBEIRO, Memoria sobre as beetrias, coutos, honras, e sua diferença, Memorias da Litteratura Portugueza, t. II, Lisboa, 1792, p. 175.

${ }^{170}$ A. Herculano, História de Portugal, v. 4, p. 298.

${ }^{171}$ A. Herculano, História de Portugal, v. 4, p. 298.
} 
Gonçalo Mendes de Sousa era o principal executor do testamento de D. Sancho I, e sua substituição pode revelar que ele se opunha aos atos de D. Afonso II que deram origem ao processo contra este movido por suas irmãs ${ }^{172}$. Ao deixar o cargo de mordomo-mor, D. Gonçalo também abandonou a corte ${ }^{173}$.

Pedro Annes era ainda o mordomo-mor quando da morte de D. Afonso II e assunção de D. Sancho II, em 1223. A partir dos últimos meses desse mesmo ano, ele foi substituído por D. Henrique Mendes, por D. Gonçalo Mendes, seu irmão, por D. João Fernandes de Vizella ou de Lima, por D. Abril Peres e novamente por D. João Fernandes de Vizella ou de Lima. Conforme A. Herculano, essas rápidas mudanças revelam a desordem causada no reino por prelados, cortesãos e barões, cada um levado naturalmente a pretender para si a suma preponderância, aproveitando-se do fato de o monarca ter herdado a coroa com aproximadamente treze anos ${ }^{174}$. Ao menos em janeiro de 1229, Pedro Annes já havia retornado ao cargo de mordomo-mor, pois nessa qualidade é que ele assina um documento ${ }^{175}$. O cargo de mordomo-mor foi extinto por D. Sancho II em 1235, em seu lugar foi criado o de meirinho-mor ${ }^{176}$.

Ao chanceler-mor cabia glosar, impedir ou negar e duvidar o efeito das leis, sentenças e determinações dos reis, quando as achassem contrárias ao direito. Nos primeiros tempos da monarquia, cumpria-lhe, também, notá-las e fazê-las escrever. O chanceler-mor ainda assinava, com os prelados, grandes do reino e demais membros do conselho, as cartas, instrumentos de doações e forais. ${ }^{177}$. Em alguns documentos, o chanceler-mor é também chamado de notário ${ }^{178}$

O primeiro chanceler do reino foi mestre Alberto ${ }^{179}$. Dos últimos anos do reinado de D. Afonso I até o princípio do de D. Afonso II, esse cargo foi exercido por Julião $^{180}$. Depois, ainda no reinado de D. Afonso II, foi chanceler o magister Petrus, deão

\footnotetext{
${ }^{172}$ A. Herculano, História de Portugal, v. 4, p. 298.

${ }^{173}$ A. Herculano, História de Portugal, v. 4, p. 16.

${ }^{174}$ A. Herculano, História de Portugal, v. 4, p. 162-80.

175 A. Herculano, História de Portugal, v. 4, p. 195.

${ }^{176}$ A. Herculano, História de Portugal, v. 4, p. 262.

177 J. A. DE FIGUEIREDO, Memoria sobre qual foi a época certa da introducção do direito de Justiniano em Portugal, Memorias da Litteratura Portugueza, t. I, Lisboa, 1792, p. 272.

${ }^{178}$ H. DA GAMA BARros, História da administração pública em Portugal nos séculos XII a XV, t. III, $2^{\mathrm{a}}$ ed., Livraria Sá da Costa, 1946, p. 218-19.

${ }^{179}$ J. A. DE FIGUEIREDO, Memoria sobre qual foi a época certa da introducção do direito de Justiniano em Portugal, Memorias da Litteratura Portugueza, t. I, Lisboa, 1792, p. 272.

${ }^{180}$ H. DA GAma Barros, História da administração pública em Portugal nos séculos XII a XV, t. III, $2^{\mathrm{a}}$ ed., Livraria Sá da Costa, 1946, p. 218-19.
} 
de Lisboa ${ }^{181}$. No início do reinado de D. Sancho II, o chanceler era D. Gonçalo Mendes, que foi sucedido, por volta de 1228, pelo mestre Vicente, deão de Lisboa e logo elevado a bispo da Guarda ${ }^{182}$. Ao mestre Vicente sucedeu Durando Froyas ${ }^{183}$. D. Domingos Jardo, que havia se doutorado em cânones em Paris, de volta a Portugal foi ordenado sacerdote, depois cônego em Évora, conselheiro de D. Afonso III, Bispo de Évora, e de Lisboa, e finalmente chanceler-mor de D. Diniz, de quem era «grande privado» ${ }^{184}$.Ao tempo de D. Pedro I foi chanceler o mestre Gonçalo das Leis ${ }^{185}$. Com D. João I, foi nomeado chanceler o doutor João Fernandes de Aregas, de Regulis, de Legibus, ou, como é mais conhecido, João das Regras.

Formado em Bolonha, João das Regras fora discípulo de Bártolo ${ }^{186}$. Foi ele quem, em 1385, convenceu as Cortes de que cabia aos povos plena liberdade para colocar a coroa sobre o mestre de Aviz, D. João I, debatendo com os que fundavam na hereditariedade o direito de ocupar o trono ${ }^{187}$.

J. A. DE FIGUEIREDO considera o chanceler o primeiro e mais antigo ofício de justiça da monarquia ${ }^{188}$. Referindo-se ao reinado de D. Sancho I, H. DA GAMA BARRos afirma que o de chanceler é o terceiro cargo na hierarquia administrativa. ${ }^{189}$.

Antes do reinado de D. Pedro, é na classe eclesiástica que vão se encontrar os homens de maior cultura, os chamados clérigos do rei ${ }^{190}$, que poderiam ter, como no caso de mestre Alberto, de mestre Pedro e de D. Domingos Jardo, também, formação jurídica.

\footnotetext{
${ }^{181}$ J. A. DE FIGUEIREDO, Memoria sobre qual foi a época certa da introducção do direito de Justiniano em Portugal, Memorias da Litteratura Portugueza, t. I, Lisboa, 1792, p. 274.

${ }_{182}$ A. Herculano, História de Portugal, v. 4, p. 177, 191, 195, 205 e 232.

${ }^{183}$ A. Herculano, História de Portugal, v. 4, p. 281.

184 J. A. DE FIGUEIREDO, Memoria sobre qual foi a época certa da introducção do direito de Justiniano em Portugal, Memorias da Litteratura Portugueza, t. I, Lisboa, 1792, p. 282.

$185 \mathrm{~J}$. A. DE FigueIREDO, Memoria sobre qual foi a época certa da introducção do direito de Justiniano em Portugal, Memorias da Litteratura Portugueza, t. I, Lisboa, 1792, p. 287.

186 J. A. DE FigueIREDO, Memoria sobre qual foi a época certa da introducção do direito de Justiniano em Portugal, Memorias da Litteratura Portugueza, t. I, Lisboa, 1792, p. 289.

${ }^{187}$ H. DA GAMA BARROS, História da administração pública em Portugal nos séculos XII a XV, t. III, $2^{\mathrm{a}}$ ed., Livraria Sá da Costa, 1946, p. 257.

${ }^{188}$ J. A. DE FigueIREDO, Memoria sobre qual foi a época certa da introducção do direito de Justiniano em Portugal, Memorias da Litteratura Portugueza, t. I, Lisboa, 1792, p. 272.

${ }^{189}$ H. DA GAMA BARROS, História da administração pública em Portugal nos séculos XII a XV, t. III, $2^{\mathrm{a}}$ ed., Livraria Sá da Costa, 1946, p. 218-19.

${ }^{190}$ H. DA GAMA BARROS, História da administração pública em Portugal nos séculos XII a XV, t. III, $2^{\mathrm{a}}$ ed., Livraria Sá da Costa, 1946, p. 260.
} 
O cargo de escrivão da puridade ${ }^{191}$ foi criado no reinado de D. Pedro I e ocupado pela primeira vez por Gonçalo Vasques, o ministro mais próximo desse rei e mais preponderante na administração do reino.

Entretanto, D. Afonso III, no ano de 1277, possuía um ministro que assinava como Petrus Petri scriptore secretorum Regis, D. Diniz tinha um secretário e a Partida II, tít. 9, lei 7, previa um notário a quem o soberano confiasse os assuntos mais secretos.

No reinado de D. Fernando, esse cargo se chamava chanceler dos selos da puridade do rei e chanceler do selo secreto.

A função do escrivão da puridade era conservar o selo de camafeu, que era o selo particular do rei. Embora pela sua natureza esse cargo devesse ser contado entre os oficiais particulares do rei, a influência que seus titulares tiveram nos destinos do reino o situa entre o dos ministros mais proeminentes da corte. Era o escrivão da puridade quem mandava distribuir as petições aos desembargadores.

As cartas de doações e privilégios deviam ser seladas com o selo do rei. Para que fossem seladas com cera, a taxa era de dez libras, e com chumbo, vinte libras.

No reinado de D. João I, durante muito tempo, o escrivão da puridade foi Gonçalo Lourenço de Gomide. O bispo de Vizeu foi escrivão da puridade de D. Duarte. Nuno Martins da Silveira e o bispo de Coimbra exerceram esse cargo sob D. Afonso V.

Sob as ordens do escrivão da puridade estavam oficiais privativos da repartição que ele dirigia.

Ao tempo de D. João I, a rainha e os infantes começaram a ter também os seus escrivães da puridade.

\subsection{OS OUVIDORES}

Termo que se aplicou aos juízes criminais de última instância e aos magistrados superiores de senhorios particulares ${ }^{192}$.

\footnotetext{
${ }^{191}$ H. DA GAMA BARROS, História da administração pública em Portugal nos séculos XII a XV, t. III, $2^{\mathrm{a}}$ ed., Livraria Sá da Costa, 1946, p. 232-37.

${ }^{192}$ H. DA GAMA BARROS, História da administração pública em Portugal nos séculos XII a XV, t. III, $2^{\mathrm{a}}$ ed., Livraria Sá da Costa, 1946, p. 260.
} 


\subsection{OS OUVIDORES DA CORTE}

Ao tempo de D. Diniz eram dois, e tinham formação jurídica ${ }^{193}$.

Uma de suas atribuições era o julgamento das apelações de sentenças interlocutórias proferidas nos feitos cíveis, conforme se depreende de uma lei de D. Diniz que passou para as Ordenações Afonsinas, Liv. III, tit. 72, § 1:

«que quando appellarem da Sentença interlocutoria, ou de qualquer, que o Juiz mande ante da Sentença definitiva nos feitos civeis, que o Juiz vaa recontar as appellaçooens aa Corte luogo no presente dia se poder, quando der a Sentença, ou em outro a mais tardar: e os Ouvidores da Corte ouçano loguo, quando lhe forem contar a appellaçom, ou em outro dia o mais tardar como dito he, e nom lhe atendam mais vogado nem a parte se ahi loguo vir nom quiser, e segundo as rasooens que lhe contar o Juiz elles julguem, o que acharem per Directo, Pero quando o Juiz contar a appellaçom na Corte, se algumas das partes ou ambas dicerem, que dicerom mais resoens, que das que se accorda o Juiz, e disserem que as querem provar, jurem loguo de malicia, esses, que o dicerem, e desde que jurarem dêem loguo as testemunhas, per que o provem perante os ditos Ouvidores; pero se essa parte disse, que lhe mínguam alguũas testemunhas, das que hy estiverom nom lhas atendam, e prove loguo pelas que quiser dar, e nom lhe atendam outras testemunhas» ${ }^{194}$.

\subsection{OS OUVIDORES DA CASA DA SUPLICAÇÃO}

Eram aqueles que, desde o reinado de D. Diniz, confirmavam as sentenças dos ouvidores da corte ou do sobrejuiz (juiz de segunda instância), conforme a Lei de 7 de julho de 1302, e a lei de 24 de abril de 1307, do livro das leis e posturas, esta última chamada de lei de 24 de abril de 1302 nas Ord. Af, III, tít. 108, § $3^{\circ}$. Conforme documentos, em 6 de maio de 1306, o ouvidor das suplicações era o Prior da Alcobaça; e em 15 de novembro de 1310 , o chantre de Évora ${ }^{195}$.

Os ouvidores da suplicação nomeados por D. Diniz eram todos jurisconsultos ${ }^{196}$.

\footnotetext{
${ }^{193}$ J. A. DE FIGUEIREDO, Memoria sobre qual foi a época certa da introducção do direito de Justiniano em Portugal, Memorias da Litteratura Portugueza, t. I, Lisboa, 1792, p. 282.

194 J. Veríssimo Álvares DA Silva, Sobre a forma dos juízos nos primeiros séculos da monarquia portugueza, Memorias de Litteratura Portugueza, t. VI, p. 56.

${ }^{195}$ H. DA GAMA BARRos, História da administração pública em Portugal nos séculos XII a XV, t. III, $2^{\mathrm{a}}$ ed., Livraria Sá da Costa, 1946, p. 264-65.

${ }^{196}$ J. A. DE FIGUEIREDO, Memoria sobre qual foi a época certa da introducção do direito de Justiniano em Portugal, Memorias da Litteratura Portugueza, t. I, Lisboa, 1792, p. 282.
} 
Segundo alguns, foi regedor da casa de suplicação o Doutor Diogo Afonso Manga-ancha, graduado em ambos os direitos, que ao tempo de D. Duarte tinha sido mandado como adjunto de embaixada ao Concílio de Basiléia, e que se tornou célebre em Bolonha $^{197}$.

\subsection{OS DESEMBARGADORES DO PAÇO}

No reinado de D. Pedro I já havia desembargadores do paço, os quais apreciavam as petições e cartas que lhes eram distribuídas pelo escrivão da puridade. Todos tinham competência para conhecer dos assuntos de justiça e graça, mas, quanto aos pedidos de graça, era necessário que fossem despachados por quatro desembargadores e certo conde, provavelmente o conde de Barcelos, D. João Afonso Tello. Os processos cíveis eram examinados por três desembargadores, dispensada a presença real. No julgamento de processos criminais, além de três desembargadores, a presença do soberano era indispensável. Os feitos da fazenda pública eram julgados por um único desembargador, mas, se importassem em concessão de mercê, era preciso que o rei estivesse presente ${ }^{198}$

Ao tempo de D. Fernando, foram desembargadores do paço (ou de petições) Vasco Gil de Pedroso, licenciado em leis, e João Gil, também licenciado em leis. Este último acumulava os cargos de conselheiro e de provedor da Fazenda ${ }^{199}$

Quando D. Afonso V era menor da idade, na regência de D. Pedro, foi desembargador do paço Luiz Martins ${ }^{200}$. O doutor Vasco Fernandes de Lucena serviu como desembargador do paço a D. Duarte e a D. Afonso V, tendo sido também conselheiro destes dois reis, chanceler da Casa do Cível, cronista-mor do Reino, guarda-mor da Torre do Tombo e conde palatino ${ }^{201}$.

\footnotetext{
197 J. A. DE FIGUEIREDO, Memoria sobre qual foi a época certa da introducção do direito de Justiniano em Portugal, Memorias da Litteratura Portugueza, t. I, Lisboa, 1792, p. 290.

${ }^{198}$ H. DA GAMA BARROS, História da administração pública em Portugal nos séculos XII a XV, t. III, $2^{\mathrm{a}}$ ed., Livraria Sá da Costa, 1946, p. 233-34.

${ }^{199}$ J. A. DE FIGUEIREDO, Memoria sobre qual foi a época certa da introducção do direito de Justiniano em Portugal, Memorias da Litteratura Portugueza, t. I, Lisboa, 1792, p. 289.

${ }^{200}$ J. A. DE FIGUEIREDO, Memoria sobre qual foi a época certa da introducção do direito de Justiniano em Portugal, Memorias da Litteratura Portugueza, t. I, Lisboa, 1792, p. 300.

${ }^{201}$ J. A. DE FIGUEIREDO, Memoria sobre qual foi a época certa da introducção do direito de Justiniano em Portugal, Memorias da Litteratura Portugueza, t. I, Lisboa, 1792, p. 301.
} 


\subsection{A CASA DO CÍVEL}

Depreende-se de um documento que em 1355 a Casa do Cível já era separada do Tribunal que acompanhava o monarca e julgava as causas criminais mais graves $^{202}$.

\subsection{O PORTEIRO-MOR, OUVIDORES DA PORTARIA E OUVIDORES DA FAZENDA}

Em uma doação régia de 1222, lê-se Portarii Maiores test., o que faz crer que havia mais de um porteiro-mor. Porém, nos documentos posteriores, esse cargo é sempre mencionado no singular: o foral de Santa Cruz, de 1225, menciona Petrus petri portarius maior. No foral d'Elvas, de 1229, serve de testemunha Joanes petri castellanus portarius major regni. Uma doação de D. Diniz a sua irmã, D. Branca, em 1280, aparece quintanam meam de Manjapção de Turribus Veteribus quae fuit Martini Ioannis, quondam portarij maioris patris mei. Na carta régia de 4 de junho de 1305, é citado «Fernam Paes, seu Porteiro mayor», que também é citado em uma doação régia de 21 de julho de 1309. Por fim, uma provisão de 21 de julho de 1321 é assinada por Domingos Paes, procurador do rei e porteiro-mor ${ }^{203}$.

Na Partida II, tít. 9, lei 14, porteiro é o oficial que tinha por função guardar a entrada da casa do rei.

A atribuição do porteiro-mor era fazer as execuções e outros atos judiciais $^{204}$.

No reinado de D. Afonso IV, as atribuições do porteiro-mor passaram para os ouvidores da portaria, um dos quais era, em 1336 e 1340, provavelmente, o mesmo Domingos Paes que em 1321 acumulava os cargos de procurador do rei e porteiro-mor ${ }^{205}$.

Os ouvidores dos feitos d'el rei e da portaria julgam, no reinado de D. Afonso IV, a legitimidade dos direitos exercidos pelos privilegiados nas suas terras. Cabelhes, também, obrigar os porteiros a repararem, por seus bens, os danos que por erro de

\footnotetext{
${ }^{202}$ H. DA GAMA BARROS, História da administração pública em Portugal nos séculos XII a XV, t. III, $2^{\mathrm{a}}$ ed., Livraria Sá da Costa, 1946, p. 266-67.

${ }^{203}$ H. DA GAMA BARROS, História da administração pública em Portugal nos séculos XII a XV, t. III, $2^{\mathrm{a}}$ ed., Livraria Sá da Costa, 1946, p. 240-41.

${ }^{204}$ H. DA GAMA BARROS, História da administração pública em Portugal nos séculos XII a XV, t. III, $2^{\mathrm{a}}$ ed., Livraria Sá da Costa, 1946, p. 241.

${ }^{205}$ H. DA GAMA BARROS, História da administração pública em Portugal nos séculos XII a XV, t. III, $2^{\mathrm{a}}$ ed., Livraria Sá da Costa, 1946, p. 241.
} 
ofício causarem aos executados. Se os bens do porteiro não bastassem, essa responsabilidade era imposta ao Fisco ${ }^{206}$.

A partir de 1372 já não se fala mais em ouvidores da portaria, mas de vedores da Fazenda. Eram dois. As Ordenações Afonsinas atribuem aos vedores da fazenda a administração superior do patrimônio real e da fazenda pública. Eram-lhe subordinados os almoxarifes, contadores e outros empregados fiscais. Despachavam alguns negócios com o rei, e outros decidiam por si sós. Julgavam em única instância os feitos das sizas, no lugar onde estava a corte. Se o feito tivesse origem em outro lugar, julgavam-no por apelação. Outros processos que interessavam ao fisco, eles desembargavam com o juiz dos feitos do rei, sem recurso.

\subsection{O CORREGEDOR DA CORTE}

Cargo que já existia em 1359. Em 1389, o concelho de Santarém pede ao rei que declare a quem deviam obedecer, se ao corregedor da comarca, ou ao corregedor da corte, porque o que um proibia, o outro mandava fazer. E o rei respondeu que onde estivesse o corregedor da sua casa, não tinha jurisdição o corregedor da comarca ${ }^{207}$.

Em 14 de março de 1410 o corregedor da corte era João Mendes, o qual servia ainda no cargo em 3 de agosto 1434, quando lhe foi mandado que realizasse uma compilação das leis, e continuou a servir no reinado seguinte, até que a morte não lhe permitiu terminar essa compilação, como menciona o proêmio das Ordenações Afonsinas $^{208}$.

Era superior aos corregedores das comarcas, mas exercia as mesmas atribuições que eles nas terras em que o rei se encontrava. Conhecia dos agravos contra decisões dos juízes ordinários, tanto cíveis como criminais, mas desde que estivessem a menos de cinco léguas. Tinha ainda competência para julgar certas causas em todo o reino, seja ratione personae, seja em razão da gravidade do delito, como por exemplo, traição, moeda falsa e sodomia. Das causas cíveis que julgava por si, cabia recurso de agravo para

\footnotetext{
${ }^{206}$ H. DA GAMA BARROS, História da administração pública em Portugal nos séculos XII a XV, t. III, $2^{\mathrm{a}}$ ed., Livraria Sá da Costa, 1946, p. 241-42.

${ }^{207}$ H. DA GAMA BARROS, História da administração pública em Portugal nos séculos XII a XV, t. III, $2^{\mathrm{a}}$ ed., Livraria Sá da Costa, 1946, p. 245.

${ }^{208}$ H. DA GAMA BARROS, História da administração pública em Portugal nos séculos XII a XV, t. III, $2^{\mathrm{a}}$ ed., Livraria Sá da Costa, 1946, p. 245-46.
} 
os desembargadores do paço, se o valor da causa ultrapassasse dez escudos de ouro. Nos feitos criminais, proferia suas sentenças definitivas em relação ${ }^{209}$.

Ao menos até 1478, esse magistrado conservava jurisdição sobre causas cíveis e criminais. Em 1488, todavia, já existem os cargos de corregedor da corte do cível e corregedor da corte do crime $\mathrm{c}^{210}$.

\subsection{O PROCURADOR DOS FEITOS DO REI NA CORTE}

A sentença de 27 de maio de 1273, dada no processo entre o rei e o mosteiro de Pombeiro, favorável ao rei, o sobrejuiz anota que ouviu ambas as partes, o que indica que o coroa tinha quem por ela requeresse em juízo. Há um documento de D. Afonso III que menciona «o procurador e o advogado do rei». Na sentença de 5 de novembro de1305, dada por Domingos Martins, clérigo do rei e ouvidor de seus feitos, menciona-se o procurador do rei, Gil Peres. Em uma lei de 1311, que proibiu a alienação de reguengos ${ }^{211}$ a pessoas privilegiadas, é mencionado, entre aqueles que aconselharam o monarca, um certo «Joham Lourenço, Vogado em minha casa», o que poderia equivaler a procurador do rei. Em 1321, Domingos Paes acumula os cargos de procurador do rei e porteiro-mor ${ }^{212}$, como já mencionado no tópico relativo ao porteiro-mor.

Conforme as Ordenações Afonsinas (I, tít. 9, e $\S \S 1$ e 2), esse cargo deveria ser ocupado por «letrado e bem entendido»; e cumpria-lhe advogar gratuitamente as causas que viessem à corte das viúvas, órfãos e pessoas miseráveis, e também servir de juiz no tribunal da corte, no impedimento de algum dos dois ouvidores, ou, no caso de discordância entre eles, se não houvesse um terceiro ouvidor para os desempatar.

\subsection{OUVIDOR DAS TERRAS DA RAINHA}

É mencionado nas Ordenações Afonsinas (I, tít. 8). Devia acompanhar a corte e julgar, no tribunal do rei, apelações dos feitos criminais. Julgava por si os processos

\footnotetext{
${ }^{209}$ H. DA GAMA BARROS, História da administração pública em Portugal nos séculos XII a XV, t. III, $2^{\mathrm{a}}$ ed., Livraria Sá da Costa, 1946, p. 246.

${ }^{210}$ H. DA GAMA BARROS, História da administração pública em Portugal nos séculos XII a XV, t. III, $2^{\mathrm{a}}$ ed., Livraria Sá da Costa, 1946, p. 246-47.

${ }^{211}$ Terras pertencentes ao patrimônio real.

${ }^{212}$ H. DA GAMA BARROS, História da administração pública em Portugal nos séculos XII a XV, t. III, $2^{\mathrm{a}}$ ed., Livraria Sá da Costa, 1946, p. 247-48.
} 
cíveis, cabendo contra suas sentenças recurso igual ao que cabia contra as sentenças do corregedor da corte.

Entretanto, é anterior a existência de um «sobrejuiz da rainha», cargo cuja criação se atribui, com alguma dúvida, ao reinado de D. Afonso III. Tinha essa autoridade nas terras da rainha jurisdição idêntica à do corregedor da corte nos outros lugares.

Se o monarca se encontrasse no território da rainha, a competência do ouvidor das terras da rainha ficava suspensa, por causa da regra de que, onde se encontrasse o rei, a justiça era administrada em seu nome, suspendendo-se todas as outras jurisdições que dele dependiam ${ }^{213}$.

\subsection{OS SOBREJUÍZES}

Sancho II criou o cargo de superiudex ${ }^{214}$.

O primeiro de que se tem registro é Petrus Martin, a partir de 1229. Depois de 1237, os documentos referem-se ao sobrejuiz Suerius Gunsaluiz. Em 1255 já havia dois sobrejuízes; em 1271, três; e em 1282, quatro ${ }^{215}$.

A função dos sobrejuízes, durante a primeira metade do século XIII, era ouvir as alegações das partes, colher os testemunhos, ler as inquirições, estudar o caso e propor à coletividade dos membros do conselho do rei a sentença. Parece, segundo SANCHEZ-ALBORNOZ, que na segunda metade do reinado de Afonso III, lhes foi delegada a função de proferir sentença, salvo naqueles casos que, por sua transcendência, exigissem a intervenção da corte.

Reconhecem-se três fases na história desse cargo: na primeira, só julgavam casos de pouca monta com independência da Corte; na segunda, foi aumentada a sua competência, reservando-se à corte apenas os casos de maior gravidade; na terceira, formaram um grau intermediário entre as justiças provinciais e a corte, podendo-se apelar das sentenças deles para o conselho do rei. Assim, o conselho se tornou um tribunal mais elevado, que julgaria não em segunda, mas em última instância, salvo naqueles casos que fossem de sua competência originária.

\footnotetext{
${ }^{213}$ H. DA GAMA BARROS, História da administração pública em Portugal nos séculos XII a XV, t. III, $2^{\mathrm{a}}$ ed., Livraria Sá da Costa, 1946, p. 248-49.

${ }^{214}$ C. SANCHEZ-ALBORNOZ, Investigaciones y documentos sobre las instituciones hispanas, Editorial Jurídica de Chile, Santiago, 1970, p. 393.

${ }^{215}$ C. SANCHEZ-AlBORNOZ, Investigaciones y documentos sobre las instituciones hispanas, Editorial Jurídica de Chile, Santiago, 1970, p. 414.
} 
Os quatro sobrejuízes nomeados por D. Diniz no princípio de seu reinado eram jurisconsultos, ou seja, tinham formação jurídica, ou porque eram portugueses e foram estudar fora do reino, ou porque eram estrangeiros por ele convidados a virem a Portugal $^{216}$.

\subsection{OS MEIRINHOS}

O cargo de maiorinus, que corresponde ao exercício da magistratura jurisdicional sobre determinado território, é muito anterior à monarquia portuguesa. $\mathrm{O}$ Concílio de Leão, de 1020, menciona muitas vezes o meirinho do rei e, no art. 17, fala conjuntamente dos condes e meirinhos. O Concílio de Coiança, no art. 7, recomenda que: omnes comites seu majorini regales populum sibi subditum per justitiam regant. E numa doação de 1097, depois dos nomes do conde D. Henrique e de D. Teresa, vem o de Diogo Gonçalves, qui est maiorinot de illa terra, e em seguida os dos dignitários da corte e prelados.

Eram escolhidos dentre os nobres de quem, por virtude e experiência, se podia esperar que exercessem bem o cargo. Não eram, em geral, letrados ou condecorados com graus acadêmicos ${ }^{217}$.

Do tempo de D. Afonso III até o tempo de D. Pedro I, designa-se por meirinho o magistrado que, em nome do rei, chefiava uma província, «fazendo justiça e tolhendo agravos» ${ }^{218}$.

Os meirinhos tinham, em seus aspectos essenciais, as mesmas funções dos corregedores. A diferença de denominação resulta na fidalguia dos meirinhos, que era dispensada para os corregedores, e na regra (nem sempre observada) de que estes últimos fossem letrados, isto é, com formação jurídica ${ }^{219}$. Assim, as atribuições dos meirinhos serão melhor examinadas no subtítulo relativo aos corregedores.

A partir do reinado de D. Afonso IV, os nomes de meirinhos e de corregedores são usados indistintamente. Há documento de 1459 que ainda menciona os

\footnotetext{
${ }^{216}$ J. A. DE FIGUEIREDO, Memoria sobre qual foi a época certa da introducção do direito de Justiniano em Portugal, Memorias da Litteratura Portugueza, t. I, Lisboa, 1792, p. 281-82.

${ }^{217}$ J. A. DE FIGUEIREDO, Memoria sobre qual foi a época certa da introducção do direito de Justiniano em Portugal, Memorias da Litteratura Portugueza, t. I, Lisboa, 1792, p. 304.

${ }^{218}$ Memoria que também levou o accessit, e tracta do direito de correição usado nos antigos tempos, e nos modernos, e qual seja a sua natureza, Memorias de Litteratura Portugueza, t. II, 1792, p. 211.

${ }^{219}$ M. CAETANO, ob. cit., p. 376.
} 
meirinhos e corregedores. A partir de 1481 os documentos se referem apenas ao corregedor $^{220}$.

No reinado de D. João I, o meirinho-mor da comarca de Entre-Douro-eMinho era Ruy Mendes de Vasconcellos; e o da de Trás-os-Montes, Nuno Viegas, o $\mathrm{Moço}^{221}$.

D. João II, por causa das parcialidades que havia no paço, instituiu o cargo de meirinho do paço ${ }^{222}$.

Não se deve confundir o meirinho que ocupava altos cargos na intrincada estrutura palaciana com o funcionário subalterno exercia atividades policiais, especialmente a captura de criminosos, e que eram mal vistos pela população, embora não pudessem ser desobedecidos. Era função análoga à do saião e do porteiro, também incumbidos do ato de citação, precursores do atual oficial de justiça ${ }^{223}$. Conforme o foral de Pombal, a pena para quem ofendesse o mordomo, o saião, as justiças e o porteiro do alcaide era o pagamento de oito soldos (Maiordomus, et Saion, et Justitiae, et Portitor de Alcaide fint cauti in 8 . sold. $)^{224}$.

\subsection{OS CORREGEDORES}

O termo corregedores recorda os correctores do Direito Romano ${ }^{225}$. Na língua portuguesa, as palavras «correger»e «corregimento», que significam «emendar»e «emenda» deram origem aos nomes «corregedor»e «correição» ${ }^{226}$.

Correição significa o direito majestático, inerente ao poder supremo, de julgar e castigar os súditos, principalmente os poderosos ${ }^{227}$.

Em 22 de janeiro de 1278, uma carta régia designa por corregedores os magistrados de última instância (sobrejuízes). Porém, só sob D. Dinis é que aparecem

\footnotetext{
${ }^{220}$ Memória que também levou o accessit, e tracta do direito de correição usado nos antigos tempos, e nos modernos, e qual seja a sua natureza, Memórias de Litteratura Portugueza, T. II, 1792, p. 212.

${ }^{221}$ Memória que também levou o accessit, e tracta do direito de correição usado nos antigos tempos, e nos modernos, e qual seja a sua natureza, Memórias de Litteratura Portugueza, T. II, 1792, p. 212.

${ }^{222}$ Memória que também levou o accessit, e tracta do direito de correição usado nos antigos tempos, e nos modernos, e qual seja a sua natureza, Memórias de Litteratura Portugueza, T. II, 1792, p. 209.

${ }^{223}$ L. C. DE AZEVEDO, O direito de ser citado, FIEO e Resenha Universitária, 1980, p. 230-31.

224 J. P. RIBEIRO, Memoria sobre as beetrias, coutos, honras, e sua diferença, Memorias da Litteratura Portugueza, t. II, Lisboa, 1792, p. 176.

${ }^{225}$ M. CAETANO, ob. cit., p. 376.

${ }^{226}$ J. P. RIBEIRO, Do direito de correição usado nos antigos tempos, e nos modernos, e qual seja a sua natureza, Memorias de Litteratura Portugueza, t. II, Lisboa, 1792, p. 185.

227 J. P. RIBEIRO, Do direito de correição usado nos antigos tempos, e nos modernos, e qual seja a sua natureza, Memorias de Litteratura Portugueza, t. II, Lisboa, 1792, p. 188.
} 
magistrados assim designados com funções territoriais definidas, mas ainda com o caráter de magistratura extraordinária. É o caso da provisão régia de 16 de janeiro de 1323, na qual Aparício Domingues é nomeado corregedor para a punição dos que seguiram a rebelião do infante. Há ainda outra provisão de D. Dinis, sem data, que menciona Afonso Rodrigues como corregedor de Entre-Douro-e-Minho. Uma lei, possivelmente de 1330, refere-se ao «meirinho ou corregedor que na terra andar»; e uma provisão de 1 de fevereiro de 1331 é dirigida ao meirinho Afonso Correia e aos corregedores de Além-Douro ${ }^{228}$.

Por uma lei de D. Diniz, de 1312, os corregedores ou meirinhos tinham o poder de «alçar» as excomunhões que os eclesiásticos impunham aos reguengueiros ${ }^{229}$, isto é, aos habitantes dos reguengos, terras pertencentes ao patrimônio real.

Atribui-se a D. Afonso IV a criação dos corregedores como magistrados permanentes, não como especiais e transitórios ${ }^{230}$.

Os corregedores receberam regimento de D. Afonso IV em $1332^{231}$, de D. Pedro I em $1340^{232}$, e de D. João I em $1418^{233}$. Este último, com alterações introduzidas pelos compiladores, veio a constituir o Título 23 do Livro I das Ordenações Afonsinas ${ }^{234}$. A legislação portuguesa sobre os corregedores é inspirada na antiga legislação da França $^{235}$, que estabelece os missi dominici, e os missi de palatio $^{236}$.

Há exemplo de concessão do poder correicional a donatário: D. Fernando, em uma doação feita à Ordem de Cristo, deu ao mestre dessa ordem o «mero e misto

\footnotetext{
${ }^{228}$ H DA GAMA BARROS, ob. cit., v. 11, p. 169.

${ }^{229}$ Memória que também levou o accessit, e tracta do direito de correição usado nos antigos tempos, e nos modernos, e qual seja a sua natureza, Memórias de Litteratura Portugueza, T. II, 1792, p. 213.

${ }^{230}$ H DA GAMA BARROS, ob. cit., v. 11, p. 170, na qual supõe que os corregedores mencionados nas Cortes de Santarém, em maio de 1331, se refiram a magistrados permanentes.

${ }^{231}$ M. CAETANO, ob. cit., p. 281.

${ }^{232}$ M. CAETANO, ob. cit., p. 376.

${ }^{233}$ M. CAETANO, ob. cit., p. 491.

${ }^{234}$ M. CAETANO, ob. cit., p. 492.

${ }^{235}$ Memória que também levou o accessit, e tracta do direito de correição usado nos antigos tempos, e nos modernos, e qual seja a sua natureza, Memórias de Litteratura Portugueza, T. II, Lisboa, 1792, p. 210-11.

${ }^{236}$ Os missi de palatio, ou «enviados do palácio», eram, na França, sob os Merovíngios, os agentes encarregados, principalmente pelos prefeitos do palácio, de alguma missão com objetivo preciso: uma inquirição, a resolução de um problema, a correção de um abuso ou de uma injustiça; ou a quem se confiava temporariamente uma circunscrição constituída de um ou vários condados. Sob Carlos Magno, a partir de 780, surgem os missi dominici, ou «enviados do senhor», que são inquiridores, inspetores ou agentes de execução. Eram enviados em número de dois, às vezes três, acompanhados de um secretário. Suas competências eram complementares, mas deviam vigiar-se mutuamente. Em geral, eram enviados juntos um leigo e um clérigo. Deviam garantir que as ordens do rei fossem cumpridas, que as capitulares fossem bem compreendidas e que a ordem pública prevalecesse. Ouviam reclamações da população e tomavam medidas para corrigir os agentes subalternos que praticassem arbitrariedades, abusos de poder e incúria. Se houvesse acusações contra o conde, recebiam instruções do rei sobre as medidas a serem tomadas. Eram, portanto, uma autoridade intermediária entre o rei e os condes (J. FAVIER, Carlos Magno, Estação Liberdade, 2004, trad. Luciano Vieira Machado, p. 290-91).
} 
império», a jurisdição e a correição sobre todas as terras da Ordem. Porém, tal correição ficava sempre sujeita à correição do próprio rei ${ }^{237}$.

H. DA GAMA BARROS, ao comentar o Regimento dos Corregedores ${ }^{238}$, assim classifica as atribuições de tais magistrados ${ }^{239}$ :

1. Exigir dos tabeliães, antes mesmo de chegarem à terra onde iam correger, que lhes apresentassem os estados para exame ${ }^{240}$.

2. Tomar providências relativas à segurança pública: mandar apregoar que ninguém encobrisse degredado, ladrão, nem outro malfeitor, nem recebesse produto de furto em sua casa, sob pena de padecer o castigo em que tivesse incorrido o ladrão ou malfeitor; depois de mandar lançar tal pregão, fazê-lo executar; ordenar aos juízes das terras que, praticado algum homicídio, grande roubo ou furto, ou qualquer outra malfeitoria extraordinária, fizessem com um tabelião sem suspeita a inquirição, da qual, uma vez concluída, deveriam logo enviar um traslado ao rei, fechado e selado com o selo dos juízes e o sinal do tabelião, conservando o original, e deveriam enviar ao corregedor o nome dos culpados, para o caso de eles se encontrarem em alguma das comarcas por onde o corregedor andasse; informar-se sobre a existência de bandos, quais os seus chefes, se deles resultavam brigas ou mortes, ou outro mal ou dano; se os bandos existissem, e os achasse prejudiciais à terra, deveria estranhar ${ }^{241}$ os culpados; se esses bandos não quisessem abster-se, castigá-los-ia, deitando-os ${ }^{242}$ da terra; ou dando-lhes outra pena, conforme o caso o exigisse, pois a punição deveria ser muito maior ao alcaide, ao juiz ou, em geral, às pessoas revestidas de autoridade pública que, por pertencerem a esses bandos, houvessem deixado de fazer direito e justiça; visitar as prisões, verificando se ofereciam a necessária segurança, e em caso negativo, mandar a quem cumprisse essa obrigação que as fizesse, tendo-se em vista que os homens destinados a guardar os presos deveriam ser homens bons e de boa fama, arraigados na terra e mancebos ${ }^{243}$; dar todas as cartas de

\footnotetext{
${ }^{237}$ Memória que também levou o accessit, e tracta do direito de correição usado nos antigos tempos, e nos modernos, e qual seja a sua natureza, Memórias de Litteratura Portugueza, T. II, Lisboa, 1792, p. 214.

${ }^{238}$ Segue esse autor o regimento que se contém em um livro mandado fazer pelo Concelho de Borba em 1347, cotejando-o com o de 1332 e o de 1340.

${ }^{239}$ H. DA GAMA BARROS, ob. cit., v. 11 , p. $170 / 183$

${ }^{240}$ Esses estados eram os registros escritos que os tabeliães eram obrigados a fazer de todas as querelas que fossem dadas, tanto a eles quanto aos juízes dos lugares onde servissem (H. DA GAMA BARROS, ob. cit., v. 11, p. 175).

${ }^{241}$ Parece-nos que, dentre os significados possíveis para esse vocábulo, os mais adequados ao sentido do texto sejam exprobrar e censurar (Dicionário da língua portuguesa, Porto, 1999, 8 a ed., p. 698).

${ }^{242}$ Isto é, expelindo-os (Dicionário da língua portuguesa, Porto, 1999, $8^{\mathrm{a}}$ ed., p. 477).

${ }^{243}$ Os quais, se os presos fugissem, padeceriam pena igual à que mereciam os fugitivos (H. DA GAMA BARros, História da administração pública em Portugal, v. 11, p. 175).
} 
segurança ${ }^{244}$, menos em feitos de morte ${ }^{245}$, mas dá-las de maneira que daí não resultasse escândalo, e mandar que ouvissem os feitos os juízes das terras, salvo se entendesse que os juízes eram tais que não podiam a tal respeito merecer confiança; o cumprimento, pelos juízes, das cartas de seguro ${ }^{246}$; nomear dois homens bons que exercessem as funções de agentes policiais $^{247}$.

3. Funções de superintendência sobre todos os que exerciam funções públicas: saber o número de advogados e procuradores que havia em cada terra, se eram tantos e tais como cumpria, ou se devia aumentar-se ou diminuir-se o seu número, procedendo a esse respeito como tivesse por conveniente; exigir dos advogados e procuradores juramento nos mesmos termos em que este era prestado na corte; mandar aos juízes que soubessem se os tabeliães observavam os preceitos que tinham jurado na chancelaria; e se achasse que não os guardavam, aplicar-lhes a pena estabelecida em tal caso; se os juízes fossem negligentes com os tabeliães, infligir-lhes-ia o castigo que entendesse necessário; saber se os almoxarifes, escrivães, porteiros, sacadores ou outros quaisquer oficiais, quando haviam de cobrar e procurar os direitos do rei, agravavam os moradores do lugar como não deviam; se, neste caso, o erro procedia de má interpretação das obrigações do cargo, recomendar-lhes-ia que não perseverassem nele; se não obstante essa recomendação, perseverassem nele, obrigá-los-ia a emendá-lo, participando ao soberano a resolução que houvesse tomado ${ }^{248}$; ordenar aos tabeliães que lhe mostrem as

\footnotetext{
244 «Consistiam as Cartas de Seguro no 'decreto em que o juiz competente concede ao réu pronunciado para captura, a faculdade de comparecer impunemente em juízo e, sob certas cláusulas, regressar solto do crime de que é acusado', explica Melo Freire. 'Promessa judicial', permitia ao réu, 'debaixo de certas condições, se eximir da prisão até a conclusão da causa', assinala Pereira e Souza» (L. C. DE AZEVEDO, ob. cit., p. 160).

${ }^{245}$ O Regimento de 1332 não menciona a atribuição do corregedor de expedir cartas de seguro, e o de 1340 a inclui sem a restrição quanto aos feitos de morte (H. DA GAMA BARROS, ob. cit., v. 11, p. 175).

${ }^{246}$ Esse cumprimento era verificado inscrevendo o corregedor em um livro todas as cartas de seguro que desse para cada terra, bem como a data em que o acusado ficava obrigado a comparecer perante o juiz. Quando o corregedor passasse novamente por aquela terra, verificaria se o acusado compareceu ou não, e se o juiz cumpriu o seu dever (H. DA GAMA BARROS, ob. cit., v. 11, p. 175).

${ }^{247}$ Esses agentes deveriam informar-se se havia chegado à freguesia algum estranho, e se este se demorasse ali mais de dois dias, deveriam participar o fato ao juiz, para se saber que homem era esse. Todos os moradores deveriam coadjuvar os agentes nessa atribuição. Além disso, indagar se na freguesia havia feiticeiros, sorteiros e alcaiotas (alcoviteiros, corretores de prostitutas), cuja existência deveriam participar ao corregedor quando este chegasse à vila ou julgado. Quando houvesse morte ou outra malfeitoria, deveriam-na participar logo às vilas e julgados da comarca, para aí serem presos os criminosos no caso de serem encontrados (H. DA GAMA BARROS, ob. cit., v. 11, p. 175).

${ }^{248}$ Isso no caso de desses funcionários não estarem sob a jurisdição dos juízes especiais dos feitos da Fazenda Pública, ou, onde não os havia, dos juízes gerais das terras. Se tais funcionários estivessem sob a jurisdição desses juízes, o corregedor obrigaria os juízes a contê-los nos limites dos seus deveres (H. DA GAMA BARROS, ob. cit., v. 11, p. 175).
} 
inquirições devassas e examiná-las ${ }^{249}$; exigir nas vilas e julgados que entregassem ao seu escrivão um rol das pessoas mais idôneas para juízes, a fim de se verificar, realizada a eleição, se esta se fizera com malícia ${ }^{250}$; tomar o juramento dos eleitos ${ }^{251}$; verificar se os tabeliães que havia nas vilas e julgados sabiam o seu ofício e tinham boa fama, e em caso negativo, escolher dentre os moradores quem fosse apto para o cargo; informar-se sobre o número de escrivães jurados que devia haver na terra, e quem se deviam dar tais ofícios; informar-se sobre os atos dos veedores ${ }^{252}$ nos assuntos das atribuições deles, nomeando tais funcionários onde não os houvesse, repreendendo-os segundo merecessem, se entendesse que haviam faltado aos seus deveres, ou nomeando outros que melhor soubessem desempenhar seus deveres, se os reputasse inábeis, de acordo com os homens bons da terra; tomar juramento dos advogados e procuradores ${ }^{253}$, o qual seria escrito no livro do tabelião que andasse com o corregedor e transcrito em livro especial dos julgados onde o advogado e o procurador exercessem a sua profissão, a fim de que os juízes fiscalizassem o cumprimento do juramento e castigassem os perjuros.

4. Fiscalizar a defesa do país e o serviço militar: entrar nos castelos a cargo dos alcaides para examinar se estavam abastecidos de armas e demais petrechos necessários, e se as torres ou andaimes careciam de conserto; informar se do estado dos muros que cercavam as vilas, mandando proceder às obras de que necessitassem, de tudo dando conta ao rei; informar-se sobre os vassalos que tinha o rei em cada vila e julgado, seus nomes e moradas, legitimidade de seus títulos, ocupações, rendimentos e se estavam preparados para o serviço do rei, dando a este conta de tudo o que apurasse; saber se os

\footnotetext{
${ }^{249}$ Se desse exame o corregedor entendesse que alguém foi absolvido por conluio ou outro motivo ilegítimo, deveria, sem demora, fazer justiça e castigar os juízes e qualquer outro culpado por tal sentença, se esta foi dada com consciência do mal que se fazia (H. DA GAMA BARROS, ob. cit., v. 11, p. 177).

${ }^{250}$ H. DA GAMA BARROS (ob. cit., v. 11, p. 177), referindo-se a essa disposição, diz: «cuja eficácia e cujo acerto hoje não podemos compreender». Parece-nos que o corregedor deveria fiscalizar se a escolha dos juízes populares recaia sobre as pessoas mais idôneas, ou se estas acabavam alijadas por qualquer motivo dessa função.

${ }^{251}$ Por disposição até então vigente, o juramento era prestado na chancelaria da corte, salvo em terras que por foro ou costume estava disso isentas. Doravante, todos os juízes deveriam prestar juramento ante o corregedor, o qual deveria reconhecer no eleito a sua idoneidade, dedicação ao serviço do rei e ao proveito da terra (H. DA GAMA BARROS, ob. cit., v. 11, p. 178).

${ }^{252}$ Homens bons que tinham a seu cargo a governança da terra (H. DA GAMA BARROS, ob. cit., v. 11, p. 178).

${ }^{253}$ Esse juramento consistia em: 1) Não levar maior salário que aquele que estava taxado; ou seja, para o advogado a vintena dos pleitos, até cem libras, e não mais, por grandes que fossem; e para o procurador a quarentena dos feitos, até dez libras, e não mais, em nenhuma hipótese; 2) Não receber mais do que a metade do salário no início do litígio, e a outra metade apenas quando ele terminasse; 3) Não colocar no feito nem mais nem menos do que a parte lhe dissesse, nem mudar a substância da causa quando fizer petições, defesas e artigos; 4) Não se encarregar de demanda que a parte entendesse não aprovar; 5) Não requerer maliciosamente; 6) Deixar o feito ao saber que a parte havia apresentado falsa prova, comunicando ao juiz a razão de seu procedimento; 7) Guardar a ordenação do rei sobre a ordem do processo (H. DA GAMA BARROS, ob. cit., v. 11, p. 178).
} 
cavaleiros das ordens militares, freires e comendadores estavam preparados para o serviço militar, e como se comportavam; nomear dois homens bons que contassem quantos moradores havia em cada freguesia e soubessem como estavam preparados para o serviço do rei; observar e fazer observar a ordenação do rei sobre besteiros do conto ${ }^{254}$; intervir no processo das aposentações do serviço militar ${ }^{255}$.

5. Fiscalizar o cumprimento dos forais, verificando se o rei deixava de receber algum direito que lhe era devido por eles, ou se recebia algo contra o foral; saber se a coroa perde alguns direitos, quer de terras, quer de jurisdição, corrigindo o que estiver em sua alçada e dando conta ao rei, em caso contrário.

6. Fiscalizar as vereações ${ }^{256}$ : empregar todas as diligências para conciliar os conselhos que tivessem demandas ou contendas entre si, e, se não o conseguir, relatar ao rei a razão da discórdia e o dano que dela podia resultar; nomear em cada vila ou lugares do seu julgado cinco ou seis homens bons, ou mais, se necessário, para superintenderem na governança $^{257}$; tomando-lhes juramento de não deixarem, por nenhum motivo, de fazer o que devessem ao proveito e honra da terra e dos seus moradores; tomar conta dos que houvessem sido procuradores do concelho nos últimos dez anos, não lhes abonando despesa alguma que não se justificasse ${ }^{258}$.

\footnotetext{
${ }^{254}$ Besteiros eram os soldados que usavam arma de arremesso, consistente de arco de aço ou madeira, cuja corda se retesava por meio de mola, que disparava setas. Os besteiros do conto eram os soldados que cada vila ou cidade era obrigada a manter em certo número.

${ }^{255}$ As aposentações do serviço militar só teriam validade se requeridas ao corregedor quando passasse na vila ou julgado em que morava o que pretendia ser aposentado, e concedidas por ele com os outros funcionários a quem de costume pertencia esta atribuição, não se reconhecendo ao aposentado outras imunidades que não fossem as que lhe estavam marcadas nos foros da sua terra (H. DA GAMA BARROS, ob. cit., v. 11, p. 180).

${ }^{256} \mathrm{O}$ cuidado no «vereamento» das terras significa a intervenção em outros assuntos de interesse geral que não os que dizem respeito à justiça (M. CAETANO, ob. cit., p. 323).

${ }^{257}$ Esses homens se reuniriam aos domingos, pelo menos à hora terça (nove da manhã), para discutir os assuntos a bem do concelho, resolvendo-os por unanimidade, ou por maioria de votos, e dando-lhes execução. Somente eles poderiam sacar tributos, dar de renda os direitos municipais, passar quitações e fazer despesa ou doação por conta dos bens do concelho. Os juízes, nos feitos de grande importância, ou naqueles em que tivessem dúvida, procederiam de acordo com esses homens bons, fazendo cumprir o que todos ou a maioria com eles concordasse a bem do concelho. Os bens desses homens bons serviriam de caução ao dano que por culpa deles padecesse a fazenda municipal, além de estarem sujeitos à imposição de pena corporal por quaisquer outras responsabilidades e segundo as circunstâncias do caso. Se algum deles, por doença ou outro motivo legítimo, faltasse às reuniões, toda a autoridade ficaria nas mãos dos outros. Entretanto, se a falta fosse por negligência ou de propósito, pagaria multa de vinte soldos aos colegas, os quais, sob juramento, não lhe poderiam quitá-la. Se por ocasião da visita do corregedor a multa não houvesse ainda sido paga, o corregedor a cobraria para si. Exceto, para evitar demoras, as cartas em feito de apelação ou de outra demanda, nenhuma carta poderia ser selada com o selo do concelho sem que eles vissem se podia passar (H. DA GAMA BARROS, ob. cit., v. 11, p. 180).

258 A partir do Regimento de Correições, as contas seriam prestadas anualmente pelos procuradores dos concelhos ao corregedor, que os obrigaria a responder pelo que houvessem recebido e pela negligência na cobrança das rendas pertencentes ao tempo das suas respectivas gerências, servindo de caução os próprios bens dos procuradores (H. DA GAMA BARROS, ob. cit., v. 11, p. 181).
} 
Pela lei de 12 de junho de 1391, conhecida como «Ordenação dos pelouros», determinou-se que em cada concelho houvesse listas de pessoas consideradas idôneas para o exercício dos diversos cargos (juiz, vereador, procurador etc.). Os nomes dessas pessoas seriam encerrados em pequenas bolas de cera, conhecidas como pelouros, e guardados em uma arca de duas chaves. No dia da renovação dos cargos municipais, abriase a arca, os pelouros eram colocados em um capuz, de onde um homem-bom sortearia aqueles que serviriam no ano seguinte ${ }^{259}$.

O Regimento dos Corregedores de 1418 alterou esse procedimento. O corregedor, ao chegar à cidade ou vila, deveria chamar à câmara os juízes, vereadores, procurador e homens-bons, os quais escolheriam seis pessoas que, duas a duas, separadamente, depois de prestarem juramento, indicassem nomes idôneos para cada cargo, em rol distinto. Entregues esses róis ao corregedor, este compararia os papéis e selecionaria os votados, encerrando os nomes deles em pelouros, os quais seriam colocados em um saco para cada função. Em seguida, esses sacos eram guardados na arca até o dia do sorteio, que seria realizado por um menino de até sete anos ${ }^{260}$.

7. Providenciar quanto à situação econômica da terra: saber em cada lugar das terras de sua comarca a razão pela qual elas se despovoavam, como se podiam povoar melhor, pondo em prática o remédio que fosse mais idôneo ${ }^{261}$; mandar as pessoas, inclusive clérigos e fidalgos se fosse o caso, que compravam pão e outros mantimentos para revender, que fossem compelidas a revendê-los quando se tornasse necessário, conforme as circunstâncias, deixando-lhes apenas os mantimentos necessários ao seu próprio consumo; punir, segundo as circunstâncias, os almotacés (avaliadores) que cometessem erros de ofício ou não cumprissem suas ordens; constranger, mediante pena corporal e pecuniária, os carniceiros e padeiras que tivessem se obrigado para com o concelho a fazer o seu ofício e o deixassem de fazer por mais de um ano, que cumprissem o seu dever; constranger os homens que tivessem em condições de trabalhar, e não tivessem profissão, nem recebessem soldo, ou vivessem às expensas de outrem, a que prestassem, no tempo oportuno, recebendo pagamento diário, os serviços necessários à agricultura, sob pena de expulsão da terra, e se aí novamente o encontrassem, nova

${ }^{259}$ M. CAETANO, ob. cit., p. 498.

${ }^{260}$ M. CAETANO, ob. cit., p. 498.

${ }^{261}$ O Regimento de 1332 desenvolve melhor esta função, determinando que o corregedor, ao descobrir que há lavradores que não cultivam nem querem cultivar as herdades que já romperam, ou não querem romper aquelas que não o fizeram ainda, diga-lhes ou induza-os o melhor que puder a que as lavrem e a que as rompam, se entender que é benefício da terra, sob pena de o rei dar essas herdades a outros que as cultivem (H. DA GAMA BARROS, ob. cit., v. 11, p. 182). 
expulsão e dez açoites ${ }^{262}$; promover as obras de proveito comum, tais como cercas das vilas, pontes, calçadas e fontes, e fiscalizar se os concelhos aplicavam a estes serviços as rendas pelo modo mais conveniente.

O corregedor deveria visitar cada lugar do seu julgado duas ou três vezes por ano, e não mais, salvo acontecendo caso extraordinário que exigisse a sua presença, quando então demoraria ali o tempo que entendesse necessário ${ }^{263}$. Nas Cortes de Santarém, em 1406, determinou-se que os corregedores visitassem todos os lugares da sua correição três vezes ao ano, não se demorando mais de oito dias em cada lugar, salvo se o interesse do Estado o exigisse ${ }^{264}$. Tal determinação foi resposta aos abusos causados aos povos pela demora de corregedores e empregados que os acompanhavam nas terras por seis, sete e até oito meses, exigindo dos moradores casa, roupas e mobília ${ }^{265}$. Se o corregedor excedesse o prazo de oito dias, ficava o procurador do concelho autorizado a requerer-lhe que se retirasse; se, apesar desse requerimento, o corregedor se conservasse no local, dava-se conhecimento do fato ao rei, por meio de carta testemunhável contendo a resposta do corregedor, que devia dá-la no prazo de três dias; se o corregedor se recusasse a responder, qualquer tabelião tinha o direito de emprazá-lo para se apresentar ao rei dentro em «três nove» ${ }^{266}$ dias, a fim de receber o castigo que ao rei aprouvesse. Entretanto, nas cortes de Lisboa de 1455, os procuradores de Viseu reclamaram ao rei de corregedores e oficiais que lá se assentavam por um ano ou mais com mulheres e filhos, não querendo andar pelas outras partes sujeitas à sua correição. Embora o rei tenha mandado que se cumprisse o prazo fixado no Regimento dos Corregedores, novas reclamações nesse sentido surgiram nas cortes de Lisboa de 1459, nas cortes da Guarda de 1465, e nas cortes começadas em Évora no ano de 1481 e acabadas no ano seguinte em Viana d'apar d'Alvito. A resposta do soberano, em 1456, é de que o prazo é de oito dias nos lugares pequenos, e de quinze dias nos outros, e que a demora além desse prazo só pode ser justificada por carta ou mandado por ele rei expedido. Já em 1481, o rei admite que, em mandado especial, pode determinar a permanência dos corregedores além dos prazos fixados, porquanto está informado de que só em quinze dias não é possível aos corregedores o desempenho de seu cargo como cumpre $^{267}$.

\footnotetext{
${ }^{262}$ No Regimento de 1340, essa pena é de duzentos açoutes (H. DA GAMA BARROS, ob. cit., v. 11, p. 183).

${ }^{263}$ H. DA GAMA BARROS, ob. cit., v. 11, p. 183.

${ }^{264}$ H. DA GAMA BARROS, ob. cit., v. 11, p. 190.

265 H. DA GAMA BARROS, ob. cit., v. 11, p. 191.

266 Provavelmente, vinte e sete dias.

${ }^{267}$ H. DA GAMA BARROS, ob. cit., v. 11, p. 191/192.
} 
A função jurisdicional dos corregedores era excepcional. Em regra, não deveriam julgar nem pleitos cíveis, nem criminais, nem lhes era lícito receber apelação das sentenças definitivas que davam os juízes da terra, salvo aquelas que, pelo seu valor, não tinham mais de uma instância, conforme as cortes de Lisboa de 1439, cap. $15^{268}$. Porém, competiam-lhes os feitos em que fidalgos, abades ou priores eram autores ou réus; a imposição de penas corporais ou pecuniárias; a correção de sentenças interlocutórias dos magistrados territoriais; o julgamento das causas em que estes eram demandados por atos de seu ofício; a avocação de causas de alcaides, juízes, advogados, procuradores, tabeliães e outros quaisquer poderosos que os juízes ordinários confessavam não ter forças para decidir, ou as em que eram suspeitos; e até, em alguns casos criminais, podia fazer reviver processos findos.

As cortes de Santarém, de 1451, se referem a uma lei de D. Duarte que fixou a duração do cargo dos corregedores em cinco anos. Porém, em 1468, estava estabelecido que os corregedores fossem mudados de três em três anos ${ }^{269}$.

Nas cortes de Lisboa de 1427, os povos se queixam a D. João I que, em vez de nomear para o cargo de corregedor indivíduos letrados, discretos e entendidos, como sempre tinha feito, escolhia agora simples estudantes, que mal sabiam escrever, e que por ignorância cometiam muitas injustiças, seguindo somente o seu alvedrio. O monarca responde que escolherá os melhores que puder, dando preferência aos letrados. Nas cortes de Évora de 1481-1482 houve novo pedido a D. João II para que os corregedores sejam letrados e saibam diferenciar e conhecer o direito como deve ser distribuído; pedido este que foi repetido nas cortes de Évora de 1490. É certo que não havia letrados em número suficiente para o provimento dos cargos de corregedores ${ }^{270}$.

Nas cortes de Évora de 1481-1482, a remuneração dos corregedores passou a vinte e quatro mil réis por ano, «outro tanto mantimento quanto costumavam ter» ${ }^{271}$. Logo, até então seus vencimentos eram de doze mil réis anuais. Esses vencimentos foram pagos pelos concelhos até 1535, data em que D. João III mandou que fossem pagos da sua fazenda $^{272}$.

Muitas eram as queixas contra as atividades dos corregedores. Nas cortes de Lisboa de 1459, disseram os povos que as correições mais propriamente se deviam chamar

\footnotetext{
${ }^{268}$ H. DA GAMA BARROS, ob. cit., v. 11, p. 183.

${ }^{269}$ H. DA GAMA BARROS, ob. cit., v. 11, p. 189.

${ }^{270}$ H. DA GAMA BARROS, ob. cit., v. 11 , p. $187 / 188$.

${ }^{271}$ H. DA GAMA BARROS, ob. cit., v. 11, p. 188.

${ }^{272}$ H. DA GAMA BARROS, ob. cit., v. 11, p. 188.
} 
danações, pois os homens que as faziam, não se lembrando de Deus nem do rei, não eram outra coisa senão destruidores públicos. De fato, em diversas cortes aparecem reclamações de que os corregedores prendiam sem motivo legal ou sem as formalidades essenciais, impediam aos juízes o exercício da jurisdição, chamavam a si o julgamento de feitos da competência dos juízes locais, levavam os autos consigo para outras terras, mandavam buscar palha e lenha sem a pagarem, mandavam revogar posturas legalmente feitas pelos concelhos, exigiam dos concelhos o pagamento aos homens que iam à corte ou a outras partes para levar seus recados ou sua correspondência, entregavam-se ao comércio em prejuízo dos mercadores locais, eram «mui brabos com os mansos» e omissos em punir algum mestre, prelado, cavalheiro ou homem poderoso, prendiam por acusação falsa sem que o denunciado tivesse ciência de quem era o delator etc. ${ }^{273}$

\subsection{ALÇADAS}

Alçadas eram correições realizadas por um ajuntamento de ministros enviados pelo soberano para conhecerem de alguns casos particulares, ou para percorrerem o reino ou alguma província, «inquirindo devassamente». Em 1430, depois de ouvir queixas do concelho de Soure a respeito de agravos que lhe fazia o mestre da Ordem de Cristo, o rei mandou que o corregedor da comarca de Estremadura o corrigisse. E D. Diniz, ao ouvir queixa dos moradores de Beja de que os donatários, nos casamentos de seus filhos, iam pelas vilas e circunvizinhanças, acompanhados do alcaide, alvazis e homens bons, pedindo galinhas, carneiros e etc., mandou um ministro para esse local, o qual determinou que não houvesse acompanhamentos, e fosse só o noivo ou a noiva ${ }^{274}$.

\subsection{OS JUÍZES DE FORA-PARTE}

O rei que primeiro mandou juízes de fora-parte aos concelhos foi D. Afonso IV, o que provocou várias queixas dos povos nas Cortes de Lisboa, em 1352. Reclamavam os concelhos que, tendo foros pelos quais elegeriam seus juízes ordinários a cada ano, os quais só eram confirmados pelo rei, este lhes mandava juízes de fora-parte, que lhes

\footnotetext{
${ }^{273}$ H. DA GAMA BARROS, ob. cit., v. 11, p.

${ }^{274}$ Memoria que também levou o accessit, e tracta do direito de correição usado nos antigos tempos, e nos modernos, e qual seja a sua natureza, Memorias de Litteratura Portugueza, t. II, Lisboa, 1792, p. 215.
} 
causavam muitas despesas. Pediam, pois, ao rei, que os deixasse eleger seus juízes segundo os seus foros e costumes. O rei respondeu que os juízes ordinários tinham muitos parentes, amigos e inimigos nos concelhos, o que prejudicava a sua isenção; além disso, como, acabada a judicatura, eles continuavam a residir no mesmo lugar como pessoas comuns, eles não aplicavam a lei e castigavam os poderosos corretamente, para não ficarem expostos à vingança; ainda, os juízes ordinários não cumpriam as disposições dos testamentos dos que morreram durante a peste; e, por fim, as despesas que os juízes de fora-parte davam aos concelhos não era prejudicial, pois esses juízes de fora-parte aumentavam as rendas dos concelhos, na medida em que mandavam lavrar e aproveitar as terras. Porém, já que estavam lhe pedindo, o rei lhes permitiria que continuassem a eleger seus juízes, alvazis ou almotacés segundo seus foros ${ }^{275}$.

Morto D. Afonso IV, D. Pedro I, seu sucessor, enviou novamente juízes de fora-parte aos concelhos que lhe pareceu que mereciam. Nas Cortes de Elvas, em 1361, de novo os concelhos reclamaram que, apesar da concessão de D. Afonso IV, o rei lhes mandava juízes de fora-parte, havendo nas vilas e cidades homens capazes para exercer o cargo de juiz ordinário; e que os salários que tinham de pagar a esses juízes de fora-parte lhes era necessário para outras finalidades. O rei respondeu que sempre fora sua vontade respeitar os foros e costumes dos concelhos, e que mandara os juízes de fora-parte para proveito deles e do reino; mas, como lhe pediam, lhes permitiria eleger a cada ano os juízes e alvazis que entendessem proveitosos às suas terras, segundo seus foros e costumes, desde que esses eleitos fizessem justiça e não houvesse motivo para castigá-los ${ }^{276}$.

Essa disposição foi observada até o final do reinado de D. Pedro I e durante todo o de D. Fernando ${ }^{277}$.

No reinado de D. João I houve graves desordens e malefícios na comarca da Beira. O rei mandou corregedores a essa comarca e, como isso não foi suficiente, resolveu ir pessoalmente até lá «correger, e emendar as ditas coisas, e reformar a mesma comarca, e torná-la ao estado em que estava no tempo dos senhores reis D. Afonso IV e D. Pedro I». O rei constatou que as «malfeitorias» eram praticadas por cavaleiros, escudeiros, homens de armas e os seus, tabeliães e outros oficiais de justiça, com o consentimento dos juízes,

\footnotetext{
275 J. A. DE FIGUEIREDO, Memoria sobre a origem dos nossos juízes de fora, Memorias de Litteratura Portugueza, t. I, Lisboa, 1792, p. 31-33.

${ }^{276}$ J. A. DE FIGUEIREDO, Memoria sobre a origem dos nossos juízes de fora, Memorias de Litteratura Portugueza, t. I, Lisboa, 1792, p. 34-35.

${ }^{277}$ J. A. DE FIGUEIREDO, Memoria sobre a origem dos nossos juízes de fora, Memorias de Litteratura Portugueza, t. I, Lisboa, 1792, p. 35.
} 
meirinhos e donatários. D. João I resolveu, portanto, ouvidos os seus conselheiros, colocar juízes em Lamego, Viseu, Guarda, Trancoso, Pinhel, Coimbra e Castelo Branco. Tal jurisdição foi extraordinária, com a finalidade de punir os crimes praticados pelos poderosos locais, sem que por causa dela cessasse a jurisdição dos juízes ordinários ${ }^{278}$.

Assim, em outros casos, quando entendia conveniente, ou quando moradores de certa vila ou cidade requeriam, o rei mandava juízes de fora-parte a determinadas localidades. As cartas que esses juízes levavam tinham o seguinte preâmbulo:

«Faço saber a vós Fidalgos, Cavalleiros, Escudeiros, Concelho, e Homens bons de tal Villa, ou de tal cidade, que confiando da bondade, e descripçom de F., e entendendo-o por nosso serviço e prol, e honra dessa Villa, ou Cidade, e por melhor regida Teemos por bem, e damoslos por nosso Juiz de Fora em essa Villa e seu Termo, assy nos feitos cíveis, como nos crimes, e no regimento, e vereamento, e apercebimento della» ${ }^{279}$.

A carta podia especificar o tempo da jurisdição do juiz de fora, havendo exemplo de durar um ano, dois, três, quatro e «enquanto nossa mercê for» ${ }^{280}$.

Dom João II continuou a nomear juízes de fora, mas foi apenas durante o reinado de D. Manuel que eles foram estabelecidos para todo o reino ${ }^{281}$.

D. Manuel costumava pagar metade dos vencimentos dos juízes de fora, cabendo a outra metade aos concelhos em que exerceriam a jurisdição, mas às vezes eram pagos pela fazenda real dois terços e quatro quintos desses vencimentos, cabendo o restante aos concelhos. Só nesse reinado é que se estabeleceu que os juízes de fora deveriam ser graduados em direito, pois antes esse requisito não era exigido ${ }^{282}$.

\subsection{OS ALCAIDES-MORES E ALCAIDES-MENORES OU PRETORES E VICE-PRETORES}

A palavra alcaide vem do termo árabe «al-kaid», e significava originalmente o chefe ou capitão de tropas. Mas, na Espanha e na África, essa palavra designava o

\footnotetext{
${ }^{278}$ J. A. DE FIGUEIREDO, Memoria sobre a origem dos nossos juízes de fora, Memorias de Litteratura Portugueza, t. I, Lisboa, 1792, p. 35-38.

${ }^{279}$ J. A. DE FIGUEIREDO, Memoria sobre a origem dos nossos juízes de fora, Memorias de Litteratura Portugueza, t. I, Lisboa, 1792, p. 38.

280 J. A. DE FigueIREDO, Memoria sobre a origem dos nossos juízes de fora, Memorias de Litteratura Portugueza, t. I, Lisboa, 1792, p. 38.

${ }^{281}$ J. A. DE FigueIREDO, Memoria sobre a origem dos nossos juízes de fora, Memorias de Litteratura Portugueza, t. I, Lisboa, 1792, p. 38-45.

282 J. A. DE FigueIREDO, Memoria sobre a origem dos nossos juízes de fora, Memorias de Litteratura Portugueza, t. I, Lisboa, 1792, p. 45.
} 
indivíduo revestido do mando supremo em um castelo ou fortaleza. Em latim, alcaide traduz-se por pretor $^{283}$.

Os alcaides eram delegados do poder real. Em regra, eram nobres, aos quais, por seus hábitos e educação guerreira, repugnava morar na vila ou cidade e cuidar da administração local. Por esse motivo, surgiu o alcaide-menor, ou vice pretor, muitas vezes denominado simplesmente alcaide, a quem o alcaide-mor nomeava como seu substituto. $\mathrm{O}$ alcaide-menor era escolhido de entre os moradores do concelho ${ }^{284}$.

Os alcaides são encontrados, de modo geral, exercendo atividade militares, administrativas e jurisdicionais nos concelhos cujo foral segue o tipo do de Santarém. Nos concelhos que tinham o foral do tipo de Salamanca, a autoridade correspondente à do alcaide era exercida pelo iudex. A diferença não é apenas na terminologia. Enquanto no alcaide a atividade militar e a representação do rei eram predominantes e a atividade jurisdicional, acessória, no iudex predominava a atividade jurisdicional ${ }^{285}$. Nos concelhos desse tipo, havia um alcaide sem qualquer jurisdicional, como, por exemplo, em Penamacor e em Salvaterra do Extremo. Nesses casos, o alcaide era um capitão de soldados estranho ao governo civil e encarregado somente da defesa do local ${ }^{286}$.

Nos concelhos cujos forais eram do tipo do de Ávila havia alcaides e juízes. $\mathrm{O}$ alcaide era nomeado pelo rei ou por um rico-homem e os juízes eram eleitos ${ }^{287}$. Nesses, o alcaide intervinha de alguma forma na atividade jurisdicional, na condição de oficial do $\mathrm{rei}^{288}$.

Nos concelhos cujos forais não correspondiam a um tipo específico, o alcaide podia ter alguma função jurisdicional, como nos que seguiam o tipo de Santarém e o de Ávila, ou não, como nos que seguiam o tipo de Salamanca ${ }^{289}$.

A partir da segunda metade do século XIII, diversos municípios obtiveram o privilégio de eleger os seus alcaides ${ }^{290}$.

\footnotetext{
${ }^{283}$ A. Herculano, História de Portugal, v. 7, p. 189-96.

${ }^{284}$ A. Herculano, História de Portugal, v. 7, p. 196-97.

285 A. HerCulano, História de Portugal, v. 7, p. 198-200.

${ }^{286}$ A. Herculano, História de Portugal, v. 7, p. 214-15.

287 A. HERCULANO, História de Portugal, v. 7, p. 218-19.

288 A. HERCUlano, História de Portugal, v. 7, p. 221-22.

289 A. HERCUlano, História de Portugal, v. 7, p. 222-23.

${ }^{290}$ A. Herculano, História de Portugal, v. 7, p. 231.
} 
Alvazil, palavra de origem árabe, derivada de «al-wasir», significava entre os sarracenos o ministro ou conselheiro do soberano. Com o tempo, essa denominação tornou-se demasiado vaga, atribuída aos chefes de qualquer ramo da administração, mas representando sempre uma delegação do poder supremo. Alcalde, também palavra de origem árabe, derivada de «al-khadi», designava o juiz de primeira instância dos muçulmanos. ${ }^{291}$.

Os alcaldes ou alvazis eram eleitos. Em Castelo Mendo, os alcaldes tinham mandato de um ano. Em Salvaterra, a aceitação do cargo era compulsória. Em Proença, vila sob a jurisdição dos templários, a eleição dos alcaldes dependia, talvez, da aprovação do preceptor da Ordem. A partir de D. Afonso III, o resultado da eleição passou a depender da aprovação do alcaide. Nos costumes de Beja, a eleição do alcaide e dos alvazis era realizada nos primeiros meses do ano, e os nomes eram apresentados ao rei, que escolhia dentre eles os alvazis gerais, que julgavam feitos cíveis e criminais, e os alvazis dos «ovençais», que julgavam as ações contra o fisco ${ }^{292}$.

Em 1315, D. Diniz determinou que os alvazis e tabeliães estivessem cada dia em concelho para fazerem as escrituras dos contratos entre os judeus e cristãos. Em 1307, ele havia determinado que os instrumentos, prazos, cartas etc. fossem assinados por cinco testemunhas e selados com o selo do concelho ${ }^{293}$.

\subsection{AS JUNTAS OU MEDIANIDOS}

Quando as partes de uma causa pertencessem a concelhos distintos, a causa era decidida por uma junta ou medianido, que eram a reunião dos magistrados dos concelhos a que pertenciam o autor e o réu. Quando os concelhos eram limítrofes, a reunião acontecia na divisa entre eles. Caso contrário, no concelho a que pertencia o réu ${ }^{294}$.

\footnotetext{
${ }^{291}$ A. Herculano, História de Portugal, v. 7, p. 176.

292 A. Herculano, História de Portugal, v. 7, p. 240-45.

293 J. VERÍsSIMO ÁlvaRes DA SILVA, Sobre a forma dos juízos nos primeiros séculos da monarquia portugueza, Memorias de Litteratura Portugueza, t. VI, p. 58-59.

${ }^{294}$ A. HerCulano, História de Portugal, v. 7, p. 269.
} 
A jurisdição dos nobres era a base de seu poderio. Nos primeiros tempos da monarquia, cada nobre podia instituir o juiz nas terras que lhe pertenciam. Há exemplo, nas inquirições de 1288 , de que, no couto ${ }^{295}$ de Luymir, onde outrora teria havido apenas um juiz, terem sido encontrados vinte, pois cada um dos fidalgos do lugar havia posto um juiz na parte do território que lhe pertencia ${ }^{296}$.

Desde 1211 as leis gerais já estabeleciam o direito de apelar para o rei, pois este, por meio do Tribunal da Corte podia conhecer de apelação das sentenças, tanto interlocutórias quanto definitivas, proferidas por juízes de qualquer lugar do reino. Todavia, só com uma lei de 1282, promulgada por D. Diniz, é que se proibiu que outros recursos se interpusessem entre a sentença e a apelação ao rei, afastando o princípio tradicional de que as apelações subiriam primeiro para os senhores das terras. ${ }^{297}$

Essa lei é reforçada por outra de 19 de março de 1317, em cuja fundamentação se percebe quantos embaraços causavam os nobres para que as apelações não chegassem ao rei.

Tais leis refletem bem a influência do direito romano, para o qual o poder de legislar e o de julgar são inerentes ao Sumo Império. No direito foraleiro, fundado na jurisdição patrimonial, era comum não só os grandes senhores darem leis a seus vassalos, como até mesmo os proibirem de se queixar ao rei. Exemplo disso é o foral de Vila Boa Jejua, de 1254, em que D. Martim Peres determina: Et Toto vicino de Villa bona, qui fuerit cum quaerimonia de sua vicino a Rege; et non quaefierit accipere judicium de vestros Juratos, pectet $x$. mrs., et exeat de Villa; et remaneat hereditate in manu de vestro Concilio. Outro exemplo é o foral de Carvalhal de Ceras, de 1216, no qual D. João Domingues estabelece: Et si aliquod illicitum feceritis sitis constitutum per nostrum Portitorem, quousque coram nobis directum faciatis, et nullus super vos habeat potestatem

\footnotetext{
${ }^{295}$ Coutos eram certos territórios em que os delinqüentes que neles entrassem ficavam livres do castigo devido por seus crimes. Eram terras que tinham o privilégio de defender os criminosos de seus inimigos. Tal instituto tem origem germânica; entre os bárbaros, o assassino ficava em guerra com a família da vítima, mas, se entrasse em um couto, os parentes do morto não poderiam lhe fazer qualquer mal. $\mathrm{O}$ couto podia ser criado pelos senhores de terras quando davam forais, ou pelo rei, com a finalidade de povoar alguma localidade. Os coutos foram abolidos em 1692 (Memoria que levou o accessit em 12 de maio de 1790, sobre as behetrias, honras, coutos e sua diferença, Memorias da Litteratura Portugueza, t. II, Lisboa, 1792, p. 176-79).

${ }^{296}$ H. DA GAMA BARRos, História da administração pública em Portugal nos séculos XII a XV, t. II, $2^{\mathrm{a}}$ ed., Livraria Sá da Costa, 1945, p. 424-25.

${ }^{297}$ H. DA GAMA BARros, História da administração pública em Portugal nos séculos XII a XV, t. II, 2ª ed., Livraria Sá da Costa, 1945, p. 426.
} 
nisi nos $^{298}$. Segundo J. Veríssimo ÁlVARES DA SILVA, em alguns lugares, os senhores chegaram a impor pena de morte e confiscação de bens aos que apelassem ao rei ${ }^{299}$.

Os senhores de terras dispunham de um mordomo, que seguia a causa em nome do autor, pactuando com este primeiramente a quantidade que lhe havia de dar. No Foral de Pombal encontra-se disposição no sentido de que, «se algum devedor não quiser pagar o seu credor, e este não o puder haver dele, fazendo composição pela décima parte do que vencer, poderá o mordomo pedir a dívida como sua». Disposição semelhante se encontra no Foral de Zezere.Isso porque os pleitos eram fonte de finanças para os senhores $^{300}$.

\subsection{A JURISDIÇÃO ECLESIÁSTICA}

Sendo a Igreja detentora de enorme patrimônio - só o mosteiro de Alcobaça possuía mais de trinta vilas -, adquirido ao longo dos séculos por meio de doações, inclusive régias ${ }^{301}$, tudo o que se expôs sobre a jurisdição patrimonial dos nobres também se lhe aplica.

Foi o Decreto de Graciano que estabeleceu o princípio de que, em nenhum caso, os juízes leigos poderiam julgar o clero $^{302}$. Em contrapartida, D. Afonso IV determinou que, nas causas da jurisdição do rei, não respondessem os leigos diante de juiz eclesiástico; e proibiu os bispos de publicarem testamentos; e D. Pedro I estabeleceu que todas as cartas que viessem da Corte de Roma não se publicassem antes do beneplácito régio $^{303}$.

A determinação de que as justiças seculares tomassem consta dos testamentos, e não as eclesiásticas, também foi feita por D. João $\mathrm{I}^{304}$.

\footnotetext{
${ }^{298}$ Memoria que também levou o accessit, e tracta do direito de correição usado nos antigos tempos, e nos modernos, e qual seja a sua natureza, Memorias de Litteratura Portugueza, t. II, Lisboa, 1792, p. 191-92.

299 J. Veríssimo ÁllVARES DA SILVA, Sobre a forma dos juízos nos primeiros séculos da monarquia portugueza, Memorias de Litteratura Portugueza, t. VI, p. 41.

300 J. VERÍSSIMO Álvares DA SILVA, Sobre a forma dos juízos nos primeiros séculos da monarquia portugueza, Memorias de Litteratura Portugueza, t. VI, p. 48 - 49.

${ }^{301}$ Memoria que também levou o accessit, e tracta do direito de correição usado nos antigos tempos, e nos modernos, e qual seja a sua natureza, Memorias de Litteratura Portugueza, t. II, Lisboa, 1792, p. 194-95.

${ }^{302}$ Memoria que também levou o accessit, e tracta do direito de correição usado nos antigos tempos, e nos modernos, e qual seja a sua natureza, Memorias de Litteratura Portugueza, t. II, 1792, p. 206.

${ }^{303}$ Memoria que também levou o accessit, e tracta do direito de correição usado nos antigos tempos, e nos modernos, e qual seja a sua natureza, Memorias de Litteratura Portugueza, t. II, 1792, p. 207.

${ }^{304}$ Memoria que também levou o accessit, e tracta do direito de correição usado nos antigos tempos, e nos modernos, e qual seja a sua natureza, Memorias de Litteratura Portugueza, t. II, 1792, p. 207.
} 
Até o tempo de D. Sebastião perdurou a ajuda do braço secular para a execução de sentenças dos juízos eclesiásticos ${ }^{305}$.

\subsection{OS TENENTES}

Tenente, ou tenens, era o rico-homem que, em nome do rei, como homem de sua confiança, se encontrava à frente de terras em nome do rei. As terras por ele governadas chamavam-se tenências ${ }^{306}$.

Como ensina M. CAETANO, atualmente, a administração econômica, política, militar etc. são completamente separadas da administração da justiça. Entretanto, essa separação só ocorreu de fato em Portugal em 1832. Até então, as diversas autoridades detinham certa jurisdição. $O$ chefe militar era juiz, o funcionário graduado da administração pública era juiz. Aliás, a administração e a justiça pertenciam, muita vez, às mesmas autoridades. Por essa razão, o tenente, embora sua função primordial fosse a chefia militar, na condição de representante do rei também governava o distrito e presidia assembléias judiciais $^{307}$.

\subsection{OS JUÍZES DOS MESTERES}

Os documentos mais antigos do período em exame revelam a superioridade do agricultor sobre o homem de ofício. Só com a coroação do Mestre de Aviz (1385) é que os homens de ofício passaram a ter algum papel na Administração Pública. Com efeito, esse rei ordenou que vinte e quatro homens, dois de cada mester, estivessem na Câmara para tudo o que se houvesse de ordenar o seu bom regimento e serviço. Para H. DA GAMA BARROS, essa é a provável origem da «Casa dos Vinte e Quatro» ${ }^{308}$, opinião refutada por M. CAETANO, para quem essa casa só foi fundada no final século $\mathrm{XV}^{309}$.

A partir daí, a importância desses homens no governo das cidades vai crescendo cada vez mais, o que provocou, diversas vezes, protestos dos nobres nas Cortes

\footnotetext{
${ }^{305}$ Memoria que também levou o accessit, e tracta do direito de correição usado nos antigos tempos, e nos modernos, e qual seja a sua natureza, Memorias de Litteratura Portugueza, t. II, 1792, p. 207.

${ }^{306}$ M. CAETANo, História do direito português, Verbo, Lisboa - São Paulo, $4^{\mathrm{a}}$ ed., 2000, p. 215.

${ }^{307}$ M. CAETANO, História do direito português, Verbo, Lisboa - São Paulo, $4^{\mathrm{a}}$ ed., 2000, p. 215-16.

${ }^{308}$ H. DA GAMA BARROS, História da administração pública em Portugal nos séculos XII a XV, t. III, $2^{\mathrm{a}}$ ed., Livraria Sá da Costa, 1946, p. 87-88.

${ }^{309}$ M. CAETANO, História do direito português, Verbo, Lisboa - São Paulo, $4^{\mathrm{a}}$ ed., 2000, p. 499-502.
} 
de Évora de 1481, e depois, nas da mesma cidade, em 1490, ocasião em que se acusavam os «plebeus dos mesteres» de não terem a ciência e maturidade necessária para reger o bem comum, de não conhecerem o que é a política, não saberem o que é a honra, nem quando a honra deve preceder o proveito. Invocavam até Aristóteles e Bártolo para argumentar que o governo das cidades não devia ser entregue aos homens de «baixa mão». Pretendia-se, além disso, que lhes fossem interditos o ofício de tabelião e quaisquer outros, quer dos concelhos, que do rei ${ }^{310}$.

E o Regimento da festa do Corpo de Deus, e de como ham de ir os Officiuos cada um em seu logar, de 1517, menciona mais de uma vez o Juiz do Ofício. ${ }^{311}$ É de se presumir que esse regimento reflita costumes anteriores.

De qualquer forma, no período em exame, os mesteres estavam sob a jurisdição dos almotacés, aos quais competia físcalizar o exercício dos vários ofícios e a observância dos preços ou taxas; aferir pesos e medidas e a honestidade de seu uso pelos mercadores; tabelar o peixe pescado e impedir o açambarcamento dele; vigiar os açougues, feiras e mercados e cuidar da limpeza da povoação. Aos transgressores, os almotacés aplicavam pesadas multas, chamadas coimas. Os almotacés davam audiência nos dias aprazados, nas quais decidiam «brevemente sem processos e sem grandes escrituras»; das suas decisões cabia apelação e agravo para os juízes municipais. Se a questão fosse de maior valor, o recurso era decidido em conjunto com os vereadores ${ }^{312}$.

\subsection{O CONSERVADOR DA UNIVERSIDADE DE COIMBRA}

Era quem julgava os feitos entre alunos da Universidade, ou entre eles e outras pessoas. Esse cargo é mencionado em uma provisão de D. Pedro I, de 13 de abril de 1361, pela qual se sabe que os estudantes se queixaram ao rei de que esse conservador julgava os litígios «somente pelos Livros, e Leis das Partidas», e não pelo direito que aprendiam nas aulas, o de Justiniano. O monarca determinou ao conservador que aplicasse

\footnotetext{
${ }^{310}$ H. DA GAMA BARRos, História da administração pública em Portugal nos séculos XII a XV, t. III, 2ª ed., Livraria Sá da Costa, 1946, p. 91-94.

${ }^{311}$ H. DA GAMA BARRos, História da administração pública em Portugal nos séculos XII a XV, t. III, 2ª ed., Livraria Sá da Costa, 1946, p. 90.

${ }^{312}$ M. CAETANO, História do direito português, Verbo, Lisboa - São Paulo, $4^{\mathrm{a}}$ ed., 2000, p. 496-97..
} 
o direito justinianeu, se os estudantes o alegassem, aconselhando-se primeiro com os letrados ${ }^{313}$.

\subsection{OS JUÍZES ORDINÁRIOS}

A investidura dos juízes ordinários se dava por eleitos pelos vizinhos do concelho em que exerceriam a sua jurisdição. Aos reis ou alguns donatários cabia a confirmação dos eleitos, ou, quando muito, a presidência da eleição, por si ou por seus oficiais. Como os vizinhos do concelho é que conheciam os respectivos forais e leis municipais que deveriam aplicar, eles escolhiam um dentre os seus para exercer o cargo de juiz ordinário ${ }^{314}$.

Eleitos, tinham jurisdição por um ano. Entretanto, se durante esse período, fossem enviados pelo rei «juízes de fora» à cidade ou vila em que judicavam, essa jurisdição cessava $^{315}$.

Não possuíam garantias. Acabado o tempo de judicatura, ficavam reduzidos a particulares, e continuavam a residir no mesmo lugar, o que os expunha a vinganças. Esse motivo, aliado ao fato de esses juízes terem na terra em que exerciam o seu cargo muitos parentes, amigos, compadres, companheiros, como também ódios e malquerenças com outros, foi constantemente invocado pelos monarcas para a nomeação de «juízes de fora», como se verá no capítulo próprio; porém, os povos durante muito tempo se insurgiram contra a nomeação de juízes de fora, reclamando o antiqüíssimo costume de que seus juízes fossem eleitos por eles próprios e dentre eles ${ }^{316}$.

Não há registro de qualquer exigência de preparo intelectual mínimo ou qualquer outro requisito para a investidura. Entretanto, numa das queixas apresentada pelos povos nas Cortes de Elvas, em 1361, ao rei D. Pedro I, contra a nomeação de juízes de fora, o argumento foi: «e auendo em esses lugares tam conuínhauees para isso como esses

\footnotetext{
${ }^{313}$ J. A. DE FIGUEIREDO, Memoria sobre qual foi a época certa da introducção do direito de Justiniano em Portugal, Memorias da Litteratura Portugueza, t. I, Lisboa, 1792, p. 285-86.

314 J. A. DE FiguEIREDO, Memória sobre a origem dos nossos juízes de fora, p. 31-32.

315 J. A. DE FIGUEIREDO, Memória sobre a origem dos nossos juízes de fora, p. 38.

${ }^{316}$ J. A. DE FIGUEIREDO, Memória sobre a origem dos nossos juízes de fora, p. 32. Lê-se no art. $7^{\circ}$ das Cortes de Lisboa que D. Afonso IV respondeu aos que se agravavam da nomeação de juízes de fora: «Porque os juyzes naturaes da terra de derecto e de Razõ am moytos aazos pera nõ fazerě compridamente justiça que nõ hã os estranhos que hí fom postosde ffora parte porque os naturaes da terra téém hí moytos parětes e amigos e outros que cõ elles hã diuídos de cõlacia e doutros semelhauijs e alguos co outos hy malquerěças e desamor. Ou hã receãça deles por os quaes o derecto presume tã compridamente nõ ffarã derecto come os estranhos ě que nõ hã logar para as dictas razões».
} 
que lhe hí eram postos» ${ }^{317}$, fica evidente que esses juízes eleitos muitas vezes não tinham qualificação inferior à dos juízes de fora.

Como um dos motivos de que se queixavam os povos em Cortes contra a nomeação de juízes de fora era a despesa que estes causavam aos concelhos, é provável que os juízes ordinários não fossem remunerados.

Esses juízes ordinários julgavam em conselho com os homens bons do lugar; mas alguns feitos, em razão da matéria ou da dignidade e graduação das partes, estavam isentos de sua jurisdição ${ }^{318}$.

De suas sentenças podia «alçar-se» ou agravar-se para os governadores, adiantados, condes, capitães-gerais ou meirinhos que os príncipes punham em cada província $^{319}$.

\section{$2.30 O$ CONCILIUM}

O concilium, palavra que deu origem aos $\operatorname{concelhos}^{320}$, eram assembléias de homens-livres, que, até o século XII, administravam a justiça nos distritos. Essas assembléias eram presididas pelo governador ou seu representante, assistido por jurados que examinavam a questão, orientavam a instrução da causa e proclamavam o direito aplicável. Ao final, o presidente proclamava o resultado, e essa proclamação era indispensável para que a sentença fosse executada ${ }^{321}$.

As fontes não oferecem certeza quanto à forma pela qual essa assembléia era convocada, mas é possível que isso se desse por diligência do saião, ou que ocorresse em reuniões regulares dos habitantes, como à saída da missa dominical ${ }^{322}$.

É afirmação de J. VERísSIMo Álvares DA SILVA que o modo como eram dadas as sentenças nesse tempo era uma barreira ao despotismo judicial, pois elas não eram proferidas por um só, mas por muitos, ou seja, os membros do conselho, e, no caso de

${ }^{317}$ Art. $9^{\circ}$ das Cortes d'Elvas.

318 J. A. DE FIGUEIREDO, Memória sobre a origem dos nossos juízes de fora, p. 31.

${ }^{319}$ J. A. DE FIGUEIREDO, Memória sobre a origem dos nossos juízes de fora, p. 31.

${ }^{320}$ M. CAETANO, História do direito português, Verbo, Lisboa - São Paulo, $4^{\mathrm{a}}$ ed., 2000, p. 219.

${ }^{321}$ J. A. ANes DuARTe NogueIRA, Sociedade e direito em Portugal na idade média, Suplemento da Revista da Faculdade de Direito da Universidade de Lisboa, Lisboa, 1994, p. 55-58. Para a prolação da sentença, depois de ouvidas as testemunhas, o conde pedia aos oficiais do Concelho os seus votos, e eles respondiam: Segundo o que dizem estas testemunhas, e segundo a vossa inquirição, nós julgamos que a partilha permaneça firme... (J. VerísSIMO ÁlVARES DA SILVA, Memoria sobre a forma dos juízos nos primeiros séculos da monarquia portugueza, Memorias de Litteratura Portugueza, t. VI, Lisboa, 1796, p. 61).

${ }^{322}$ J. A. ANEs DuARTE NogUeIRA, Sociedade e direito em Portugal na idade média, Suplemento da Revista da Faculdade de Direito da Universidade de Lisboa, Lisboa, 1994, p. 59. 
esses membros não saberem o direito que competia à ação, eram também consultados os homens-bons que estavam presentes, o que se chamava judicium per turbam ${ }^{323}$.

\subsection{AUXILIARES DA JUSTIÇA}

No início da monarquia portuguesa, de acordo com as leis visigóticas, os instrumentos poderiam ser lavrados por quaisquer particulares, chamados notários, desde que observadas certas formalidades: o dia e o ano em que era feito, as testemunhas e partes o firmavam com os seus sinais, não devia ser feito por servo, se a parte estava doente, podia assinar uma testemunha em seu nome, mas essa testemunha tinha seis dias para comparecer diante de um sacerdote na presença de outras testemunhas, e fixavam uma pena convencional à parte que os quebrasse. As escrituras dos primeiros reinados que ainda restam são exatas em indicar o ano em que foram feitas, e, além disso, muitas vezes, indicavam também a era de César, o ano do reinado, o ano da fundação da terra em que eram feitas, e a pena à parte que arredasse da convenção ${ }^{324}$.

Havia uma interessante técnica para evitar falsificações. Na mesma folha de papel ou pergaminho se faziam duas cartas, entre as quais se punham as letras A, B e C. A folha era partida pelo meio dessas letras, levando cada parte o seu instrumento. Se surgisse dúvida a respeito da legitimidade de algum dos instrumentos, bastava juntá-lo ao outro para ver se as letras se completavam exatamente ${ }^{325}$.

A partir do Reinado de D. Afonso II é que se encontram tabeliães públicos em Portugal. Como eram nomeados pelo rei e tomavam posse na chancelaria régia, eram chamados de tabeliães do rei. A partir de 1305, não mais podiam ser clérigos. Além de sua atribuição tradicional de lavrar escrituras, serviam nas audiências dos juízes e nas reuniões da vereação e do concelho; registravam as leis recebidas da corte; inventariavam os bens dos órfãos, registravam os delitos públicos; tomavam nota das querelas entre particulares e das decisões dos pleitos por sentença ou composição das partes. Distinguem-se dos escrivães porque estes eram secretários de determinada autoridade ou adjuntos a certo ofício. Aos escrivães cumpria escreverem o expediente da autoridade que secretariavam,

\footnotetext{
${ }^{323}$ J. VERÍSSIMO ÁLVARES DA SILVA, Memoria sobre a forma dos juízos nos primeiros séculos da monarquia portugueza, Memorias de Litteratura Portugueza, t. VI, Lisboa, 1796, p. 42.

${ }^{324}$ J. VERISSIMO ÁLVARES DA SILVA, Memoria sobre a forma dos juizos nos primeiros seculos da monarquia portugueza, Memorias da Litteratura Portugueza, t. VI, Lisboa, 1796, p. 59.

${ }^{325}$ J. VERISSIMO ÁlVARES DA SILVA, Memoria sobre a forma dos juizos nos primeiros seculos da monarquia portugueza, Memorias da Litteratura Portugueza, t. VI, Lisboa, 1796, p. 60.
} 
registrando suas decisões. Com o tempo, aos escrivães foi outorgado o poder de elaborar documentos com fé pública ${ }^{326}$.

Outros auxiliares da justiça eram os já mencionados meirinhos, saiões, porteiros, andadores do concelho e fiéis. Dada a multiplicidade de forais, não é possível estabelecer com exatidão as atribuições de cada um deles. $\mathrm{O}$ saião tem origem no direito visigótico, e era o cumpridor das ordens reais e o executor das decisões judiciais. Esses cargos, como todos os do concelho, eram temporários, e a nomeação, em regra, era por um $\mathrm{ano}^{327}$. 


\section{REMINISCÊNCIAS DA ORGANIZAÇÃO JUDICIÁRIA MEDIEVAL PORTUGUESA NO BRASIL CONTEMPORÂNEO}

A primeira indagação necessária ao se comparar a organização judiciária portuguesa medieval à do Brasil contemporâneo é o que se espera do juiz ideal, quais seus atributos ideais. Com efeito, é a partir da pessoa do juiz que se pode conhecer como a atividade jurisdicional se exerce em determinada época.

Com a consciência de que toda simplificação é temerária, cumpre examinar os critérios com que diversos autores descreveram o «juiz ideal» ao longo da história.

Segundo F. DE Coulanges, na antiguidade, tanto em Atenas quanto em Roma, o que se esperava do magistrado é que fosse amado dos deuses; não se buscava o mais corajoso, nem o mais hábil, nem o mais justo, mas aquele fosse apto a cumprir as funções sacerdotais ${ }^{328}$. É o que corresponde à concepção sacral do direito, comum às civilizações antigas.

Na idade média, e precisamente no período estudado, esperava-se que o juiz fosse virtuoso. S. Tomás de Aquino e outros teólogos aceitaram a definição de Ulpiano de que a «justiça é a vontade constante e perpétua de dar a cada um o que é seu». A conseqüência disso foi que aspectos da vida privada dos candidatos à magistratura passaram a servir para a aferição de seu mérito, o qual era indissociável da função que eles exerceriam $^{329}$.

No período iluminista, não obstante outros requisitos como nacionalidade, idade mínima de vinte e cinco anos e experiência na advocacia, a exigência primordial ao candidato era a ciência, presumível a partir do diploma universitário ${ }^{330}$.

Hoje, no Brasil, defende-se que o Judiciário seja:

«provido por profissionais dotados de espírito crítico, criativos e imbuídos da missão de atuar na transformação da sociedade» ${ }^{331}$.

E ainda:

«o juiz deve ser encarado como um gerente de empresa, de um estabelecimento. Tem sua linha de produção e o produto final, que é a prestação jurisdicional. Tem de terminar o processo, entregar a sentença e a execução. Como

\footnotetext{
${ }^{328}$ F. DE Coulanges, A cidade antiga, EDIPRO, $3^{\mathrm{a}}$. ed., São Paulo, 2001, p. 159.

${ }^{329}$ A. P. BARBAS HOMEM, Iudex perfectus, Almedina, Coimbra, 2003, p. 134.

${ }^{330}$ A. P. BARBAS HOMEM, Iudex perfectus, Almedina, Coimbra, 2003, p. 329-34.

${ }^{331}$ J. R. NALINI, A rebelião da toga, Millenium, Campinas, 2008, $2^{\mathrm{a}}$ ed., p. 85.
} 
profissional de produção é imprescindível mantenha o ponto de vista gerencial, aspecto da atividade judicial que tem sido abandonado» ${ }^{332}$.

Para outro autor:

«o candidato a juiz deverá demonstrar que tem condições para avaliar com independência, equilíbrio, objetividade e atenção aos aspectos humanos e sociais, as circunstâncias de um processo judicial, tratando com igual respeito todos os interessados e procurando, com firmeza e sinceridade, a realização da justiça» ${ }^{333}$.

As idéias giram em torno desses eixos: eficiência, capacidade de transformação social, promoção dos direitos humanos.

Portanto, uma diferença crucial a extrair dessas definições de «juiz ideal» ao longo da história, que contrapõem, de um lado, o juiz antigo, medieval e moderno, e de outro, o juiz contemporâneo, é o fato de que, para os primeiros, os requisitos de seleção estavam voltados para aspectos da personalidade: piedade, virtude, ciência, enquanto que para o último esses requisitos se voltam para o resultado esperado da atividade jurisdicional, variando esse resultado conforme a perspectiva ou posição ideológica de cada autor.

Como conseqüência, aspectos valorizados em outros tempos já não o são para doutrinadores do Brasil contemporâneo.

Com relação ao requisito da ciência, que tanto prestígio teve no recrutamento de magistrados no período do iluminismo, hoje se apregoa:

«o juiz não é profissional instituído para tecer brilhantes considerações literárias, doutrinárias ou de erudição. Pode ele ter também conhecimento que o alce à condição de doutrinador, mas para isso, em princípio, deverá procurar outros campos de atividade, que não o jurisdicional. Fará concursos, defenderá teses, exercerá atividade docente permitida. O processo, entretanto, não é destinado a esse tipo de preocupação, conquanto a fundamentação seja sempre necessária. No processo, a tônica deve ser decidir e executar, razão pela qual, aliás, é preciso pensar, em cada decisão, já na maneira de execução segura» ${ }^{334}$

Em contraposição ao modelo de juiz virtuoso medieval, apresenta-se hoje a aspiração ao juiz ético, com a expressa advertência de que, ao se falar em ética, não se está a falar de moralidade, pois ao «juiz ético» são indiferentes as «múltiplas configurações da

\footnotetext{
${ }^{332}$ S. A. BENETI, Da conduta do juiz, Saraiva, São Paulo, 1997, p. 12.

${ }^{333}$ D. DE ABreu DAllari, $O$ poder dos juízes, Saraiva, São Paulo, $3^{\text {a }}$ ed., 2008, p. 28.

${ }^{334}$ S. A. BENETI, Da conduta do juiz, Saraiva, São Paulo, 1997, p. 12-13.
} 
família, as parcerias sexuais» etc. A ética é valorizada enquanto «alavanca da eficiência» ${ }^{335}$.

À piedade que devia caracterizar o juiz da antiguidade, o Brasil contemporâneo, que nisso segue a civilização ocidental, opõe o princípio da laicidade.

Diante do confronto entre requisitos tão díspares para o exercício da magistratura vale a pergunta: é possível encontrar ainda alguma reminiscência da organização judiciária medieval no Brasil contemporâneo?

Tal pergunta não pode ser respondida sem que se repita a advertência feita no início deste capítulo, a da consciência da temeridade das simplificações.

Mesmo que predominasse na idade média o ideal do juiz virtuoso, o conhecimento teórico, ainda que não ocupasse posição de proeminência, nunca foi menosprezado. Já se expôs como os soberanos portugueses procuraram se cercar de pessoas com formação jurídica (jurisconsultos) desde o início da monarquia; no início, de monges; depois, de religiosos e leigos formados no exterior; e após a criação do Studium, daqueles que nele se graduavam, sem esquecer outros que recebiam formação no exterior, como o célebre João das Regras. Além disso, na medida em que aumentava o número de pessoas com formação jurídica, estas passaram a ocupar os cargos da magistratura. Numa das Cortes, os povos pediram ao rei que nomeasse magistrados com formação jurídica, e o rei respondeu que, na medida em que os houvesse, nomeá-los-ia. O fato de a suposta virtude do candidato ser o fator principal, determinante, não excluía a ciência como atributo apreciável no magistrado.

Quanto à virtude, o mérito pessoal, ainda que menos estudado pelos autores contemporâneos, permanece para a sociedade em geral como um atributo ínsito ao magistrado, e isso se comprova pela fórmula de tratamento ainda hoje empregada: «meritíssimo juiz». Não se sugeriu alterá-la para «sapientíssimo juiz», nem para «eficientíssimo juiz», o que demonstra que a fórmula em uso resquício do ideal medieval de juiz, não é vazia de significado.

Quanto à estrutura do Poder Judiciário no Brasil contemporâneo, tanto na hierarquia quanto na nomenclatura dos cargos judiciais, as reminiscências são ainda mais palpáveis.

Com a ressalva de que atualmente é muito mais nítida, por força de princípio constitucional, a separação de poderes, o juiz de direito exerce o cargo

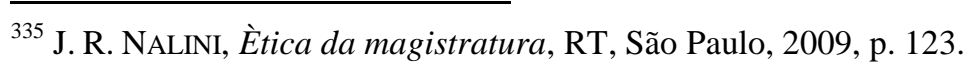


correspondente ao juiz de fora-parte medieval português; o desembargador ainda hoje é o juiz de segunda instância, aquele que desembarga, que afasta os embargos, os obstáculos à formação da coisa julgada; o juiz corregedor tem ainda hoje muitas das atribuições que tinha na idade média portuguesa, sendo a audiência de instalação da correição um resquício muito claro da origem desse cargo.

O Brasil também conserva a nomenclatura de escrivão (adjunto a uma autoridade) e tabelião (o que lavra escrituras), e a distinção medieval entre esses cargos ainda é válida.

Outras designações permaneceram, mas com sentido já completamente deturpado. À guisa de exemplo, há no Tribunal de Justiça de São Paulo um ouvidor cujas funções em nada lembram o ouvidor português medieval. Trata-se de cargo não remunerado, criado pela Resolução n. ${ }^{\circ}$ 162, de 26 de novembro de 2003, que deve ser ocupado por desembargador aposentado, com mandato de dois anos, vedada a recondução, ao qual incumbe receber, verbalmente, por escrito ou qualquer outro meio, reclamações, críticas ou sugestões, ainda que sigilosas, relacionadas aos serviços judiciais, encaminhálas aos responsáveis para as providências cabíveis, e informar ao interessado a solução adotada.

A multiplicidade de jurisdições também pode ser atribuída à herança medieval portuguesa. Há no Brasil uma Justiça Comum Estadual, uma Justiça Comum Federal, cada qual com seus Juizados Especiais, uma Justiça do Trabalho, uma Justiça Militar e uma Justiça Eleitoral. Tudo isso só é compreensível com a lembrança da jurisdição eclesiástica, da jurisdição dos nobres, da jurisdição do rei, da jurisdição municipal etc.

Persiste principalmente um forte componente burocrático, decorrente do emaranhado de cargos, da superposição de órgãos judiciários, aliado ao formalismo da legislação processual - tudo motivo para a criação de novos organismos na vã esperança de simplificação, como, por exemplo, o Conselho Nacional de Justiça.

No que diz respeito a garantias processuais, muitas práticas introduzidas na época das Leis Gerais em Portugal mantiveram-se e são hoje essenciais em nossa cultura jurídica: o duplo grau de jurisdição, a garantia do direito de apelação e de agravo, consolidada no reinado de $\mathrm{D}$. Diniz, o processo escrito, redigido em vernáculo, a proibição de penhora privada. O Tribunal do Júri, garantia constitucional no Brasil, é resquício do concílium de homens bons. 
De qualquer modo, muitos dos princípios hoje aplicados ao Poder Judiciário são posteriores à idade média e com ela incompatíveis, razão pela qual não se pode considerar a organização judiciária do Brasil contemporâneo como evolução da portuguesa medieval.

Toda mudança de princípios implica reorganização. Aliás, isso já ocorrera durante o período estudado, quando a adoção do direito de Justiniano acarretou o paulatino desaparecimento do direito foraleiro e consuetudinário, com ele incompatível.

No direito consuetudinário e foraleiro, a autonomia municipal era muito forte. Cada cidade era como que uma pequena república:

«a descrição da sociedade política nos autores pré-iluministas obedeceu ainda a um outro tipo de considerações, que podemos considerar de cariz essencialmente medieval, isto é, não associável à filosofia política greco-latina. A construção do poder político como uma constelação de repúblicas - concelhos, comunidades, universalidades, sociedades - é típica do pluralismo político jurisdicional medievo» ${ }^{336}$.

Já o direito de Justiniano é essencialmente centralizador. Segundo N. Bobbio, a redescoberta do direito romano e a imensa obra de modernização e interpretação levada a cabo por juristas leigos e eclesiásticos, pelas escolas e orientações que se sucederam na Europa até o século XVII propiciou uma mudança cultural importante, na qual o «bom direito antigo», de natureza sacra, «achado» em normas consuetudinárias, naturais e divinas, desde tempos imemoriais foi abandonado, e cedeu seu lugar ao direito «criado» pelo príncipe, segundo as necessidades do tempo e baseado em técnicas mais modernas $^{337}$. Foi por meio desse direito que o príncipe deixou de ser predominantemente juiz para se tornar legislador.

E esse príncipe que legisla é incompatível com um direito baseado no costume, e variável de uma vila para outra.

Assim como não é possível afirmar que a redescoberta do direito romano tenha sido uma evolução do direito foraleiro e consuetudinário, não é possível ver no direito brasileiro contemporâneo, especialmente no que se refere à organização judiciária, uma evolução do direito português medieval.

É possível falar-se em «organização judiciária» durante o período objeto desta pesquisa? Aquele que considerar como absolutos valores que só apareceram nos séculos posteriores, tais como soberania do Estado, separação dos poderes, laicidade,

\footnotetext{
${ }^{336}$ A. P. BARBAS HOMEM, Iudex perfectus, Almedina, Coimbra, 2003, p. 65.

${ }^{337}$ N. Bobbio, N. MATEUCCI e G. PASQuino, Dicionário de política, UNB, Brasília, 1983, $9^{\mathrm{a}}$ ed., p. 3 (verbete «absolutismo».
} 
magistratura de caráter público, ingresso na magistratura mediante concurso público, independência funcional, juiz natural etc., provavelmente responderá que não, que o que havia então uma verdadeira «desorganização judiciária», caracterizada pela confusão entre poderes: bispos e clérigos se imiscuindo em tribunais, o papa julgando processos e depondo reis, advogados (procuradores do rei) substituindo sobrejuízes em caso de impedimento, juízes ordinários eleitos, outros juízes nomeados pelo rei, particulares exercendo alguma espécie de jurisdição (mesteres, por exemplo), ausência de qualquer garantia para o juiz ordinário depois de terminada a sua judicatura, suspensão da competência dos juízes pela simples presença da corte a um raio de cinco léguas de distância etc., etc., etc.

Mas aquele que percebe a relatividade dos princípios jurídicos que se consagraram posteriormente, que só fazem sentido em nossa época e por causa de circunstâncias históricas identificáveis, responderá que sim, que havia uma verdadeira organização judiciária, com sua lógica, sua coerência e seus méritos.

Não se pretende fazer aqui a apologia da idade média em Portugal. Muitos dos que viveram naquela época tinham plena consciência de que a organização judiciária de então não era perfeita. Os reis de Portugal, durante quase um século, criticaram a eleição de juízes dentre os habitantes dos concelhos. Se o que perturbava a consciência do soberano era apenas o que ele expunha nessas críticas, ou se elas também encobriam seu interesse no uso dos juízes de fora-parte para o fortalecimento do poder real, pouco importa; o que se pode afirmar com convicção é que essas críticas eram procedentes, irrefutáveis; contra elas os habitantes dos concelhos só puderam objetar a antiguidade da instituição, não a sua conveniência. E quanto ao abuso de poder por parte dos corregedores, as sucessivas reclamações em Cortes mostram o quanto esse novo cargo instituído pelo rei foi recebido com antipatia.

Não se admite, porém, subestimar a idade média. Ela já foi exageradamente caluniada ao longo dos séculos. Boa parte dos estudiosos consultados para esta pesquisa, principalmente aqueles que escreveram no apogeu do iluminismo, não deixaram de usar lugares-comuns como época «de barbárie», «de trevas», «de ignorância» etc.

O que se quer demonstrar é que, apesar das diferenças, dos séculos que nos separam, dos valores que a sociedade contemporânea adotou como pétreos e dos valores que eram sagrados para aqueles medievais e que os séculos posteriores confrontaram e 
contestaram, aqueles nossos antepassados tinham uma noção muito clara de que o juiz existe apenas e tão-somente para dar a cada um o que é seu (tribuere).

E a partir dessa noção souberam forjar o duplo grau de jurisdição, a possibilidade de pedir a alguém investido de autoridade que se lhe fizesse justiça, o processo escrito e em língua vulgar, a inadmissibilidade da vingança privada.

Seja o rei que quer que os juízes não tenham amizade nem desamor por uma das partes, sejam os concelhos que querem que seu corregedor não lhes cause mais despesa do que o necessário, todas essas preocupações trazem ínsito o anseio de um juiz que dê a cada um o que é seu. E ainda hoje, o que se debate no Brasil do século XXI é, no fundo, exatamente isso. Enquanto o juiz, seja ele bispo, clérigo, nobre, rei, mester, analfabeto, letrado, magister, nomeado, eleito, de fora-parte, militar, for capaz de dar a cada um o que é seu, haverá uma ciência para estudar qual a melhor forma de fazê-lo, e essa ciência terá sua história pesquisada com interesse. 


\section{CONCLUSÕES}

1. Não é possível considerar a organização judiciária brasileira como evolução da organização judiciária medieval portuguesa.

2. Entretanto, nossa organização judiciária conserva importantes reminiscências desse período, tais como a percepção social do mérito pessoal como requisito para o exercício da atividade judicial, a nomenclatura dos cargos, a multiplicidade de jurisdições sobre a mesma base territorial, a estrutura hierarquizada e «burocrática» do serviço.

3. A crescente influência do direito justinianeu em Portugal, com o conseqüente declínio do direito foraleiro e consuetudinário, implicaram a mudança da concepção do rei como juiz para a do rei como legislador, e essa mudança foi um fator importante para o fortalecimento do poder real, com repercussões nos séculos subseqüentes.

4. A criação do cargo de corregedor foi um marco na crescente intervenção do rei nas múltiplas jurisdições dele não diretamente dependentes.

5. A criação do cargo de juiz de fora assegurou a influência do poder real na administração da justiça.

6. A idéia que muitos autores fazem do analfabetismo dos órgãos judicantes, bem como da falta de cultura jurídica das personagens envolvidas na administração da justiça, não é exata. Apesar de o Estudo Geral só ter sido fundado por D. Diniz em 1290, antes disso muitos portugueses freqüentaram a Escola de Bolonha e outras. Além disso, diversos estudiosos estrangeiros foram atraídos ao reino pelos monarcas anteriores e gozaram de grande prestígio e autoridade, influenciando diretamente nos destinos de Portugal. E ainda antes da fundação das Universidades, o Direito sempre foi cultivado entre alguns eclesiásticos, nos mosteiros, conforme o demonstram os diversos exemplares de livros jurídicos encontrados nas bibliotecas monacais. É razoável supor que, em razão desse estudo do Direito, esses eclesiásticos tivessem um papel de orientação quanto à aplicação da justiça, até porque, na época do direito foraleiro, a atividade notarial era exclusiva ou predominantemente exercida por eles.

7. Não é indiferente investigar-se se os mestres receberam formação jurídica em escolas monásticas ou episcopais. Isso porque, enquanto nos mosteiros havia 
um apego à tradição gótica, junto às catedrais havia já o estudo do direito romanocanônico.

8. Não repugnava aos costumes da época que os juízes, no caso de não serem letrados, consultassem quem tinha formação jurídica antes de decidirem, e que sua decisão se pautasse por essa consulta. 


\section{BIBLIOGRAFIA}

ABREU DALLARI, Dalmo, O poder dos juizes, Saraiva, São Paulo, $3^{\mathrm{a}}$ ed., 2008.

ANES DUARTE NOGUEIRA, José Artur, Sociedade e direito em Portugal na idade média, Suplemento da Revista da Faculdade de Direito da Universidade de Lisboa, Lisboa, 1994.

ALMEIDA COSTA, Mario Julio de, História do direito português, Almedina, Coimbra, $3^{\mathrm{a}}$ ed., 2008.

ANÔNIMO, Memoria que levou o accessit em 12 de maio de 1790, sobre as behetrias, honras e coutos, e sua differença, Memorias de Litteratura Portugueza, t. II, Lisboa, 1792.

ANÔNIMO, Memoria que também levou o accessit, e tracta do direito de correição usado nos antigos tempos, e nos modernos, e qual seja a sua natureza, Memorias de Litteratura Portugueza, t. II, Lisboa, 1792.

AZEVEDO, Luiz Carlos de, Introdução à história do direito. RT, São Paulo, $2^{\mathrm{a}}$ ed., 2007.

, O direito de ser citado, FIEO - Resenha Universitária, São Paulo, 1980.

; LOBO DA COSTA, Moacyr; Estudos de história do processo Recursos, FIEO - Joen (co-edição), São Paulo, 1996.

BARBAS HOMEM, Antonio Pedro, Judex perfectus - função jurisdicional e estatuto judicial em Portugal - 1640-1820, Almedina, Coimbra, 2003.

BENETI, Sidnei Agostinho, Da conduta do juiz, Saraiva, São Paulo, 1997.

BOBBIO, Norberto; et alii, Dicionário de política, UNB, Brasília, $9^{\text {a }}$ ed., 1997.

CAETANO, Marcello, História do direito português, Verbo, Lisboa - São Paulo, $4^{\mathrm{a}}$ ed., 2000.

CORREIA, Alexandre; SCIASCIA, Gaetano, Manual de direito romano, v. I, Saraiva, São Paulo, 1949. 
COULANGES, Fustel de, A cidade antiga, EDIPRO, São Paulo, $3^{\mathrm{a}}$ ed., 2001 .

CRUZ E TUCCI, José Rogério; AZEVEDO, Luiz Carlos de. Lições de processo civil canônico, RT, São Paulo, 2001.

_ Lições de história do processo civil lusitano, $1^{\mathrm{a}}$ ed., São Paulo, RT e Coimbra Editora (co-edição), 2009.

CRUZ E TUCCI, José Rogério, Precedente judicial como fonte do direito, RT, São Paulo, 2004.

ESPINOSA GOMES DA SILVA, Nuno J., História do direito português, Fundação Calouste Gulbenkian, Lisboa, $4^{\mathrm{a}}$ ed., 2006.

FAVIER, Jean, Carlos Magno, Estação Liberdade, São Paulo, 2004, trad. Luciano Vieira Machado.

FERREIRA DA CUNHA, Paulo; et alii, História do direito, Almedina, Coimbra, 2005.

FIGUEIREDO, José Anastásio de, Memoria sobre qual foi a época da introducção do direito de Justiniano em Portugal, Memorias da Litteratura Portugueza, T. 1, Lisboa, 1792.

— Memoria sobre a origem dos nossos juízes de fora, Memorias da Litteratura Portugueza, T. 1, Lisboa, 1792. , Memoria sobre qual seja o verdadeiro sentido da palavra façanhas, que expressamente se achão revogadas em algumas leis, e cartas de doações e confirmações antigas, como ainda se acha na Ord. liv. 2 tit. 35 § 26, a origem dos nossos juízes de fora, Memorias da Litteratura Portugueza, T. 1, Lisboa, 1792.

GAMA BARROS, Henrique da, História da administração pública em Portugal nos séculos XII a XV, t. III, 2ª ed., Livraria Sá da Costa, 1946

GILISSEN, John. Introdução histórica ao direito. Lisboa: Fundação Calouste Gulbenkian, 1998.

HERCULANO, Alexandre, História de Portugal, t. I a VIII, Livrarias Aillaud \& Bertand - Livraria Francisco Alves, Paris - Lisboa - Rio - São Paulo - Belo Horizonte, $8^{\mathrm{a}}$ ed.

LE GOFF, Jacques, São Luis - Biografia, Record, Rio de Janeiro, 2002. 
, SCHIMITT, Jean-Claude, Dicionário temático do ocidente medieval, v. I e II, EDUSC, Bauru, 2006.

NALINI, José Renato, A rebelião da toga, Millenium, Campinas, 2008.

. Ética da magistratura, RT, São Paulo, 2009.

SANCHEZ-ALBORNOZ, Claudio, Investigaciones y documentos sobre las instituciones hispanas, Editorial Jurídica de Chile, Santiago, 1970.

PERNOUD, Régine, Luz sobre a idade média, Publicações EuropaAmérica, Mira-Sintra, 1997.

RIBEIRO, João Pedro, Memorias sobre as fontes do código philippino, Memorias de Litteratura Portugueza, t. II, Lisboa, 1792.

RIBEIRO, João Pedro, Qual seja a época da introducção do direito das decretaes em Portugal, e o influxo que o mesmo teve na legislação portugueza, Memorias de Litteratura Portugueza, t. VI, Lisboa, 1796.

RIBEIRO, João Pedro, Fontes do código philipino, Memórias da Literatura Portugueza, Tomo II, 1792.

Qual seja a época da introdução do direito das decretais em Portugal, e o influxo que o mesmo teve na legislação portugueza, Memórias da Literatura Portugueza, Tomo VI, 1796.

SANCHEZ ALBORNOZ, Una ciudad de la España cristiana hace mil anos, Rialp, Madrid, $6^{\mathrm{a}}$ ed., 1976.

SANTA ROSA DE VITERBO, Frei Joaquim de, Elucidario das palavras, termos, e frases que em Portugal antiguamente se usarão, e que hoje regularmente se ignorão, T. II, Typographia Regia Silviana, Lisboa, 1799.

SANTA SÉ, Código de direito canônico, tradução da Conferência Nacional dos Bispos do Brasil, notas, comentários e índice analítico do Pe. Jesus Hortal, Loyola, São Paulo, 2003.

VERÍSSIMO ÁLVARES DA SILVA, José, Sobre a forma dos juízos nos primeiros séculos da monarquia portugueza, Memorias da Litteratura Portugueza, t. VI, Lisboa,

VILLA-NOVA PORTUGAL, Thomaz Antonio de, Qual seja a epocha fixa da introducção do direito romano em Portugal, e o grao de authoridade que elle teve nos diversos tempos, Memorias da Litteratura Portugueza, Tomo V, Lisboa. 
WIEACKER, Franz, História do direito privado moderno, Fundação Calouste Gulbenkian, $3^{\mathrm{a}}$ ed., Lisboa, 2004. 


\section{RESUMO}

À primeira vista, o estudo da organização judiciária em Portugal ao tempo das Leis Gerais (1211-1446) sugere uma desorganização judiciária, um sistema sem coerência interna, em virtude da multiplicidade de fontes do direito e de jurisdições. Ainda assim, a convivência da herança visigótica, o costume, os usos da corte, o direito canônico e o direito romano «redescoberto» coexistiram por três séculos. Os juízes da época eram designados pelo rei, pelos nobres, pela Igreja ou eleitos pelos concelhos. O papa exercia jurisdição e sua autoridade prevalecia sobre o rei, que por sua vez a exercia em questões originárias e em grau de recurso. A exigência essencial em relação aos magistrados era a virtude, qualidades morais, mais do que ciência ou estudo formal, que, no entanto não eram menosprezados. A tradição oral deu lugar à forma escrita. A introdução das leis gerais acabou por extinguir a vingança privada e instituir garantias ainda observadas no Brasil atual, agora com o status de direitos fundamentais. A instituição de corregedores e juízes de fora serviu ao propósito de fortalecer o poder real. 


\section{RÉSUMÉ}

À première vue, l'étude de l'organisation judiciaire au Portugal à lépoque des lois générales suggère une «désorganisation», un système sans coherence interne, à cause de la multiplicité de sources de droit e de juridictions. Et pourtant l'héritage visigothique, la coutume, les usages de la Cour, les anciennes coutumes du royaume, le droit canonique e le droit romain «retrouvé» coexitaient pendant trois siècles. Les juges étaient designés par le roi, le nobles ou l'Église ou élus par les «concelhos» (conseils de ville). Le pape exerçait jurisdiction, dans laquelle son autorité prévalait sur le roi. Celui-ci exerçait juridiction originelle et en dernière instance. L'exigeance essentiel envers les magistrats était la vertu, des traits de charactère morales, en plus que la science ou apprentissage, qui n'étaient point méprisées. La tradition orale a donné lieu à la forme écrite. L'établissement de lois génèrales engendra l'extinction de la vengeance privée e l'apparition de plusieurs garanties, qui ont acquis, au Brésil actuel, le status de droits fondamentaux. L'institution $\mathrm{du}$ «corregedor», magistrat désigné pour fonctions correctionnelles, et de «juízes de fora» (juges d'outre-terre) a servi au but de renforcer le pouvoir du monarque. 
